\title{
Demosponges from the Northern Mid-Atlantic Ridge shed more light on the diversity and biogeography of North Atlantic deep-sea sponges
}

\author{
PACO CÁRDENAS ${ }^{1,2,5}$ AND HANS TORE RAPP ${ }^{1,3,4}$ \\ ${ }^{1}$ Department of Biology, University of Bergen, PO Box 7803, N-5020 Bergen, Norway, ${ }^{2}$ Department of Systematic Biology, \\ Evolutionary Biology Centre, Uppsala University, Norbyvägen 18D, 75236 Uppsala, Sweden, ${ }^{3}$ Centre for Geobiology, University of \\ Bergen, Bergen N-5007, Norway, ${ }^{4}$ Uni Research, Uni Environment, Bergen N-5006, Norway, ${ }^{5}$ Current address: Department of \\ Medicinal Chemistry, Division of Pharmacognosy, BioMedical Center, Husargatan 3, Uppsala University, 75123 Uppsala, Sweden
}

\begin{abstract}
In July-August 2004, the Mid-Atlantic Ridge Ecosystems (MAR-Eco) expedition collected Demospongiae (Porifera) from the Northern Mid-Atlantic Ridge (MAR) north of the Azores, between $41^{\circ} \mathrm{N}$ and $61^{\circ} \mathrm{N}$. Demosponges were found at 10 stations, at depths ranging from 753 to $3046 \mathrm{~m}$. Twenty-two species were identified: 17 Tetractinellida, one Polymastiida, one Suberitida, two Poecilosclerida and one Dendroceratida. The study of this material is an opportunity to revise the taxonomy and the North Atlantic distribution of each of these deep-sea species. Some species are particularly rare and poorly known (Tetilla longipilis, Tetilla sandalina, Craniella azorica, Polymastia corticata) and two are new to science: Forcepia (Forcepia) toxafera sp. nov. and Iotroata paravaridens sp. nov. This study suggests that the MAR is not a longitudinal barrier for the dispersal of deep-sea demosponges while on the contrary, the Charlie-Gibbs Fracture Zone (CGFZ) may be a latitudinal border for the dispersal of deep-sea demosponges, due to great depths and currents.
\end{abstract}

Keywords: Porifera, Demospongiae, taxonomy, Mid-Atlantic Ridge, Charlie-Gibbs Fracture Zone, amphi-Atlantic, MAR-Eco, Tetractinellida, Geodia, new species

Submitted 9 March 2015; accepted 3 June 2015; first published online 6 August 2015

\section{INTRDDUCTION}

The Mid-Atlantic Ridge (MAR) between Iceland $\left(63^{\circ} \mathrm{N}\right)$ and the Azores $\left(36-39^{\circ} \mathrm{N}\right)$ spans across $3000 \mathrm{~km}$. About mid-way between Iceland and the Azores (around $52^{\circ} \mathrm{N}$ ), the Charlie-Gibbs Fracture Zone (CGFZ) offsets the MAR about $300 \mathrm{~km}$, with depths reaching $4500 \mathrm{~m}$ (Felley et al., 2008), thereby opening the deepest connection between North-East and North-West Atlantic waters (Figure 1). Furthermore, a northern branch of the North Atlantic Current (NAC) crosses the Mid-Atlantic Ridge from west to east just over the CGFZ while being under the influence of colder subpolar waters on its northern border. The CGFZ area is thus considered a major latitudinal transition zone in the environment and biodiversity of the MAR (Vecchione et al., 2010) and is now part of the world's first network of marine protected areas (MPAs) by both OSPAR (Oslo-Paris Convention) and the NEAFC (North-East Atlantic Fisheries Commission) (O'Leary et al., 2012). Therefore, the poorly explored MAR and CGFZ in particular are of considerable interest for deep-sea biodiversity and biogeography studies. The

Corresponding author:

P. Cárdenas

Email: paco.cardenas@fkog.uu.se
Mid-Atlantic Ridge Ecosystems (MAR-Eco) project (2001-2010, www.mar-eco.no), part of the 'Census of Marine Life' (www.coml.org), was aimed at studying the patterns and processes of the ecosystems of the northern Mid-Atlantic. In July-August 2004, the Norwegian RV 'G.O. Sars' collected benthic samples on the MAR between the Azores and the southern region of the Reykjanes Ridge. Most of the material has already been identified and published, notably in special issues of 'Deep-Sea Research Part II' and 'Marine Biology Research' in 2008 (http:// www.tandfonline.com/toc/smar20/4/1-2, http://www.sciencedirect.com/science/journal/o9670645/55/1, both accessed 15 April 2014). Taxa examined and studied in these special issues include fish, fish parasites, Cetacea, corals, copepods, planktonic cnidarians and ctenophores, Holothuroidea, pourtalesiid sea urchins, Isopoda (Aegidae), Ophiuroidea, Anthozoa, Asteroidea, Echiura, Sipuncula, Brachiopoda and Hexactinellida. Additional taxa checklists of benthic organisms, including a preliminary demosponge species list of our identifications, were added and discussed by Gebruk et al. (2010). In the present paper, we update and refine this checklist while thoroughly describing and discussing the taxonomy of each species. Indeed, the study of this material is an opportunity to revise some poorly known Atlantic deep-sea species. We also compiled distribution maps for most of these species. They will form the basis of 


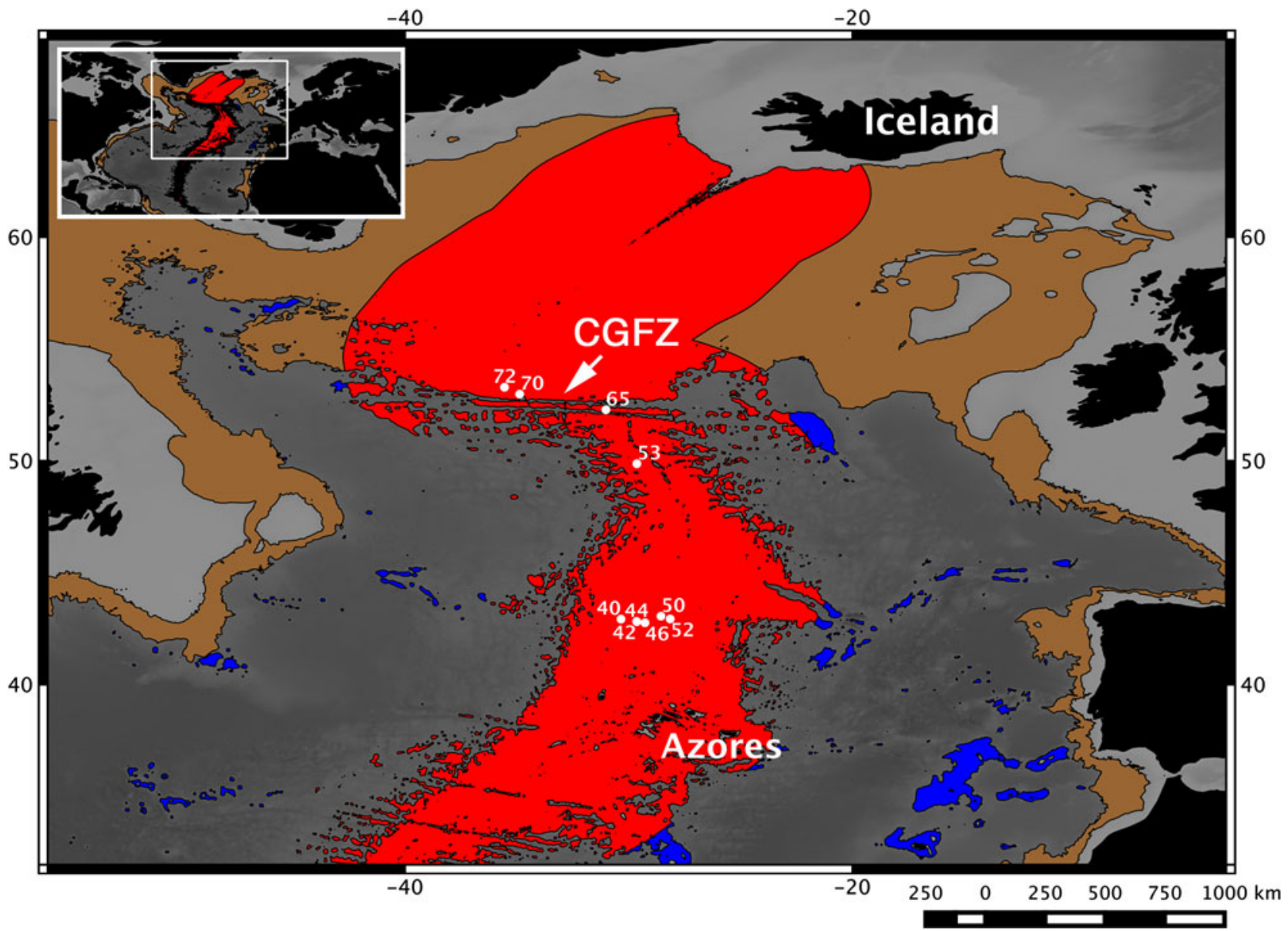

Fig. 1. Map of the North Atlantic Ocean highlighting the lower bathyal zones (depths $800-3500 \mathrm{~m}$ ) on the Mid-Atlantic Ridge (red), continental margins (brown) and non-contiguous seamounts (blue). Dark grey areas are abyssal zones. Light grey areas are the shallower continental margins and coast (depths o-8oo m). Black areas are land areas. The 10 MAR-Eco super stations where demosponges were collected are plotted on the map. 'CGFZ': Charlie-Gibbs Fracture Zone. Map made with QGIS v2.2, http://www.qgis.org, and modified from Niedzielski et al. (2013, Figure 1).

a discussion on the biogeography of deep-sea demosponges in the North Atlantic.

\section{MATERIALS AND METHDDS}

\section{Sponge sampling}

Sponge specimens were collected by bottom trawl on board the RV 'G.O. Sars' during Leg 2 (4 July-5 August) of the 2004 MAR-Eco expedition (cf. cruise report at http://www. mar-eco.no/sci/cruises/expedition_report_rv_g.o.sars_2004, accessed 8 March 2014). The trawl was a Campelen 1800 shrimp trawl with a $22 \mathrm{~mm}$ mesh size cod-end liner and a $12-17 \mathrm{~m}$ by $4.5 \mathrm{~m}$ opening at $50 \mathrm{~m}$ doorspread. Environmental data associated with the trawls were nearbottom measurements obtained with a CTD sensor (Søiland et al., 2008). For a detailed station list with coordinates, depths and environmental data, and for a full account of the approach and methods for sampling of the benthic fauna during this expedition, see Bergstad \& Gebruk (2008). Demosponges were found at 10 stations, at depths ranging from 753 to $3046 \mathrm{~m}$ (Table 1, Figure 1): two stations were on the north-west of the CGFZ (stations 72 and 70), two shallower stations $(<1000 \mathrm{~m})$ were on MAR seamounts (stations 65 and 53), and finally six stations were north of the Azores (stations 40, 42, 44, 46, 50 and 52). Specimens were preserved in $4 \%$ buffered formaldehyde on board and later transferred to $70 \%$ ethanol. Specimens are stored at room temperature in the Bergen Museum (ZMBN).

\section{Morphology studies}

To collect the spicules, sponge tissue was digested in nitric acid on a microscope glass slide. Spicules were then washed with water and with ethanol $96 \%$ and mounted in Euparal; 25 spicules per spicule type were measured, unless otherwise stated. Measurements of all spicules were made with a light microscope. Width of triaene rhabdomes was measured right under the cladomes. Width of the oxeas was measured in the middle. For Thenea species, we only measured microscleres because megascleres have been shown to be similar in North Atlantic Thenea (Cárdenas \& Rapp, 2012). Some of these spicules were placed on a stub, coated with a gold/palladium mix and observed with the ZEISS Supra 55VP and JEOL JSM-840A scanning electron microscopes (SEM) at the Laboratory of Electron Microscopy, University of Bergen. Thick sections $(100-800 \mu \mathrm{m})$ were made with a diamond wafering blade and a low speed saw using an Agar Low Viscosity Resin kit (C) Agar Scientific) in accordance with the manufacturer's mixing instructions to make a hard embedding medium. Digital pictures of these sections were taken with a Nikon 
Table 1. List of the 22 Demospongiae collected by the 2004 MAR-Eco expedition. Temperature, salinity and oxygen data obtained with near-bottom measurements with a CTD sensor (Søiland et al., 2008).

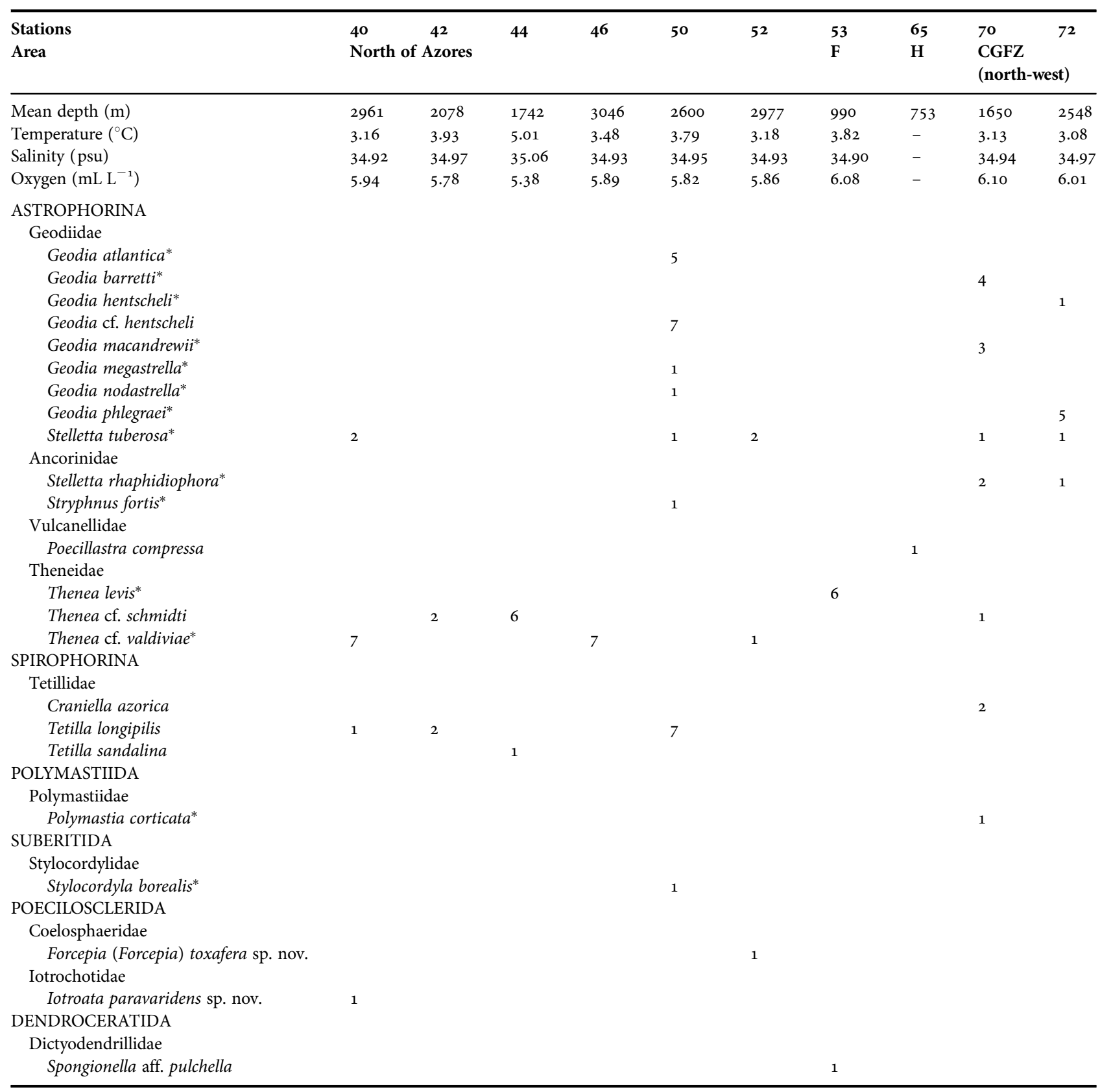

CGFZ, Charlie Gibbs Fracture Zone; F, Faraday Seamount; H, Hecate Seamount.

*Amphi-Atlantic species.

camera fixed to a stereomicroscope (Leica M216 A). Thick sections, spicule preparations and SEM stubs are stored in the Bergen Museum. With respect to taxonomy, our study will follow the demosponge classification proposed by Morrow \& Cárdenas (2015).

\section{Distribution maps of species}

All the records obtained from our identifications and the literature were compiled and mapped with GeoMapApp v. 3.3.9 (http://www.geomapapp.org), using the North Polar base map projection and the default Global MultiResolution Topography Synthesis (Ryan et al., 2009). When the latitude/longitude information was missing but the locality was given, we reconstructed the geographic coordinates using Google Earth. Distribution maps of boreo-arctic Geodia species have been updated from Cárdenas et al. (2013), by adding the MAR-Eco records and records from the Reykjanes Ridge (Copley et al., 1996). Additional records were also added for (i) Geodia atlantica from the Kerry Head Reefs cruise CV13012 (August 2013, chief scientist: Louise Allcock, material sorted by C. Morrow, identifications by PC) and for (ii) Geodia macandrewii from the Porcupine Bank (CE13008 campaign, June 2013, RV 'Celtic Explorer' using the ROV 'Holland I', chief scientist: Louise Allcock, material sorted by C. Morrow, identifications by PC). Maps of boreo-arctic Thenea species and Poecillastra compressa have also been updated from Steenstrup \& Tendal (1982) 
and Cárdenas \& Rapp (2012), with new records from the CE13008 campaign, the NEREIDA campaigns (see acknowledgements for more details, material sorted by M. Best, identifications by PC), as well as groundfish bottom trawl surveys carried out by the Spanish Institute of Oceanography (IEO) and the European Union (EU) on board the Spanish RV 'Vizconde de Eza'. We also added records of specimens examined in the collections of the Zoological Museum in Copenhagen (ZMUC): this includes records of $P$. compressa (Danish Ingolf Expedition 1895-1896), Stryphnus fortis (Ingolf), Tetilla longipilis (Ingolf, BIOICE 1991-2004), Stelletta tuberosa (Ingolf), Stelletta rhaphidiophora (Ingolf, Lynch 1972-1973, BIOICE, Paamiut 1994) and Stylocordyla borealis (BIOICE, BIOFAR 1987-1993, Michael Sars 1902). We also re-examined Thenea spp. specimens from museums in Monaco (MOM) and Stockholm (SMNH). More records came from underwater picture databases: that of the Marine area database for Norwegian waters (MAREANO, http:// www.mareano.no) and that of habitat mapping studies in the West Shetland Channel (pictures courtesy of K. L. Howell) (Howell et al., 2010). We also used the Global Biodiversity Information Facility (GBIF) website (http://www.gbif.org, accessed 22 April 2014) to retrieve records of Stylocordyla borealis from the eastern US coast, from specimens stored at the Yale Peabody Museum (2009; specimen data records available through distributed digital resources). The compiled records used for the species distribution maps - including geographic positions (decimal degrees coordinates), museum collection or reference, temperature and salinity when available - can be found in the Supplementary material.

\section{Abbreviations}

The following abbreviations are used for the institutions from which we have examined material, or where material will be deposited. BIO: Bedford Institute of Oceanography, Halifax, NS, Canada; GNM: Göteborg Natural History Museum, Sweden; Mc: National Museums, Northern Ireland, Holywood; MNHN: Museum of Natural History, Paris, France; MOM: Oceanographic Museum of Monaco, Monaco; NHM: The Natural History Museum, London, UK; PC: Private Collection, Department of Biology, UoB, Norway (HTR, PC); RMNH: The State Museum of Natural History, Leiden, the Netherlands; SMF: Senckenberg Museum, Frankfurt, Germany; SMNH: Swedish Museum of Natural History, Stockholm; UPSZMC: The Zoological Museum of Uppsala, Sweden; ZMAPOR: The Zoological Museum, University of Amsterdam, the Netherlands; ZMUC: The Zoological Museum, Copenhagen, Denmark; ZMBN: Bergen Museum, Norway.

\section{RESULTS}

Table 1 lists the 22 demosponge species identified per station: 14 species belonged to the Astrophorina and three to the Spirophorina so that a total of 17 species belonged to the order Tetractinellida. The other five species belonged to the orders Polymastiida (one), Suberitida (one), Poecilosclerida (two) and Dendroceratida (one). An advantage we had when studying this collection is that most of the Astrophorina identified in this collection had been revised using morphological (Cárdenas \& Rapp, 2012; Cárdenas et al., 2013) and molecular data (Cárdenas et al., 2011) so we will often refer to these revisions for additional information. Specimens cited in the aforementioned papers have been used as comparative material.

SYSTEMATICS

Class DEMOSPONGIAE Sollas, 1885

Subclass HETEROSCLEROMORPHA Cárdenas et al., 2012

Order TETRACTINELLIDA Marshall, 1876

Suborder ASTROPHORINA Sollas, 1887

Family GEODIIDAE Gray, 1867

Genus Geodia Lamarck, 1815

Geodia atlantica (Stephens, 1915)

(Figures 2A \& 3)

MATERIAL

Five specimens from the same trawl, Station 50-373, $2610 \mathrm{~m}$ : ZMBN 105633, 105637, 105639, 105641-42.

\section{OUTER MORPHOLOGY AND SKELETON}

ORGANIZATION (FIGURE 3A-C)

Massive subspherical specimens which can be flattened (105639, 105642). 105633 is about $3 \mathrm{~cm}$ in diameter, and attached to a Geodia cf. hentscheli. 105637 is a small subspherical specimen about $1 \mathrm{~cm}$ in diameter. Specimens 105639, 105641 and 105642 stick together along with one Stryphnus fortis and one Stelletta tuberosa (Figure $3 \mathrm{~A}$ ). Uniporal oscules and cribriporal pores. Colour in ethanol is whitish to light brown. Surface is smooth and slightly bumpy ('deflated' appearance). Cortex is $0.5 \mathrm{~mm}$ thick. Thick sections were made for 105639 and 105642. The choanosomes of 105639 and 105642 are filled with numerous foraminifera. In these specimens also, anatriaenes are rare and oxyasters I are very numerous (as in the holotype) (Figure $3 \mathrm{C}$ ). Skeleton organization is similar to that described in Cárdenas et al. (2013).

SPICULES, ZMBN 105639 (FIGURE 3D-H)

Megascleres: (a) oxeas, straight or bent, length: 31253325-3675 $\mu \mathrm{m}$; width: 32-35.4-40 $\mu \mathrm{m}$. (b) orthotriaenes, rare dichotriaenes, straight or slightly bent rhabdome, rhabdome length: 1525-2237.5-2600 $\mu \mathrm{m}(\mathrm{N}=6)$; width: 51-60.5-70 $\mu \mathrm{m}(\mathrm{N}=27)$; orthotriaene clad length: $290-$ 376.1-480 $\mu \mathrm{m} \quad(\mathrm{N}=18)$; protoclad length: $150-210 \mu \mathrm{m}$ $(\mathrm{N}=2)$; deuteroclad length: $75-230 \mu \mathrm{m} \quad(\mathrm{N}=2)$. (c) anatriaenes, straight or slightly bent rhabdome, width: 18-19.3-20 $\mu \mathrm{m}(\mathrm{N}=3)$; clad length: 205-230-245 $\mu \mathrm{m}$ $(\mathrm{N}=3)$. Microscleres: (d) sterrasters, spherical, length: 84-99.7-120 $\mu \mathrm{m}(\mathrm{N}=21)$, smooth rosettes. (e) spheroxyasters, rough actines, $7.5-10-12.5 \mu \mathrm{m}$ in diameter. (f) oxyasters I, rough actines, diameter: $29-56.4-83 \mu \mathrm{m}$. (g) oxyasters II, rough actines, usually with a larger centrum than oxyasters I, diameter: $12.5-21.8-35 \mu \mathrm{m}$.

BATHYMETRIC RANGE

65-2610 m (Cárdenas et al., 2013; this study).

\section{DISCUSSION}

Spicule measurements and morphologies fit with the description of this species (Cárdenas et al., 2013). But the asters are clearly more strongly spined than in the NEA specimens (including the type). Also, the sterrasters are spherical, like in NWA specimens, whereas they were more 

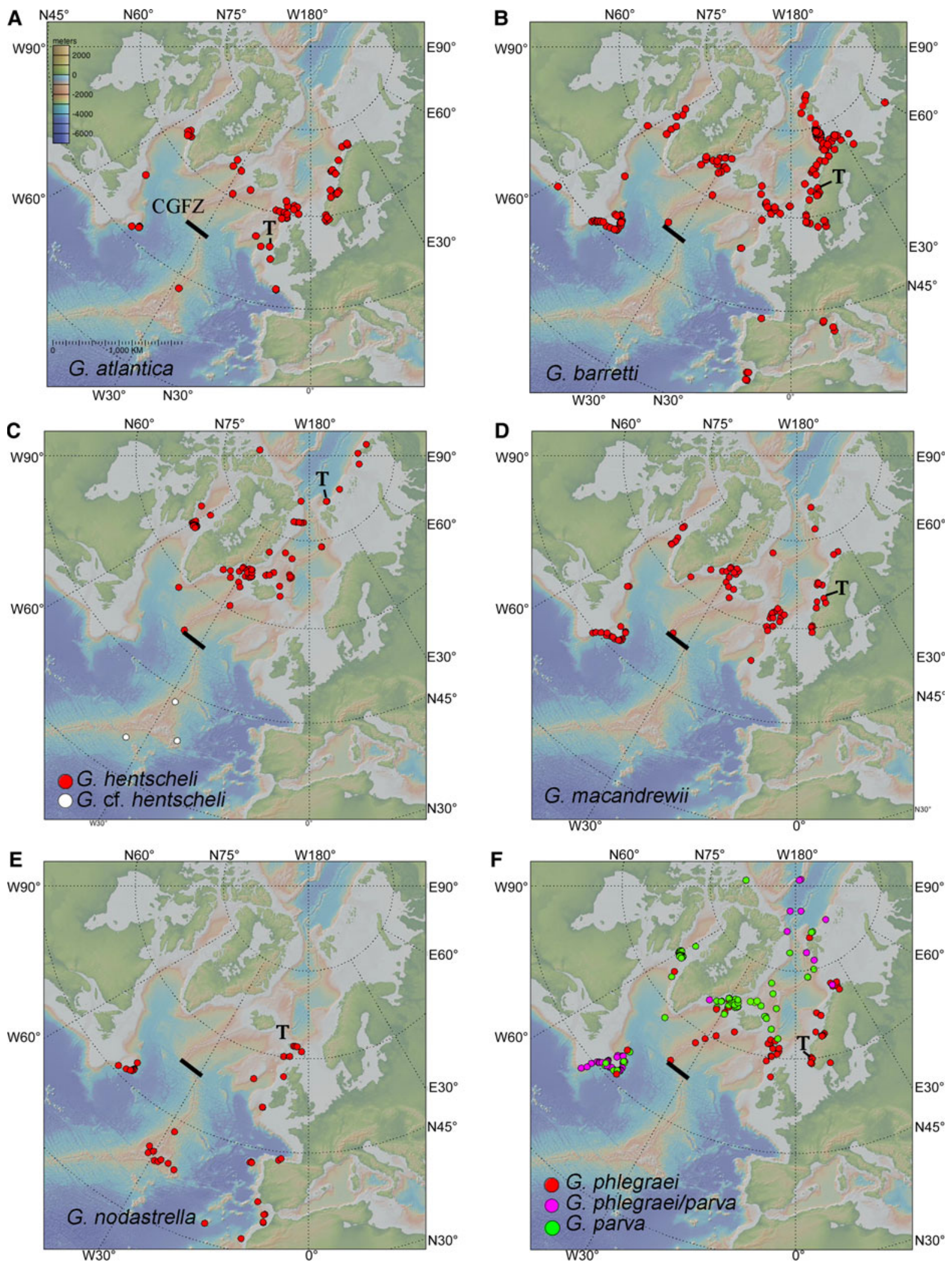

Fig. 2. Distribution maps. T, type locality; CGFZ, Charlie-Gibbs Fracture Zone. Maps generated with GeoMapApp 3.3 (http://geomapapp.org).

elongated in NEA specimens. Although dichotriaenes are usually rare in this species, they are particularly common in specimens 105633 and 105637 . The external morphology is a bit different from more northern specimens as well: darker colour and 'deflated' surface appearance. To conclude, as suggested before (Cárdenas et al., 2013) there could be a southern morphotype of G. atlantica, to which the MAR-Eco specimens belong. 

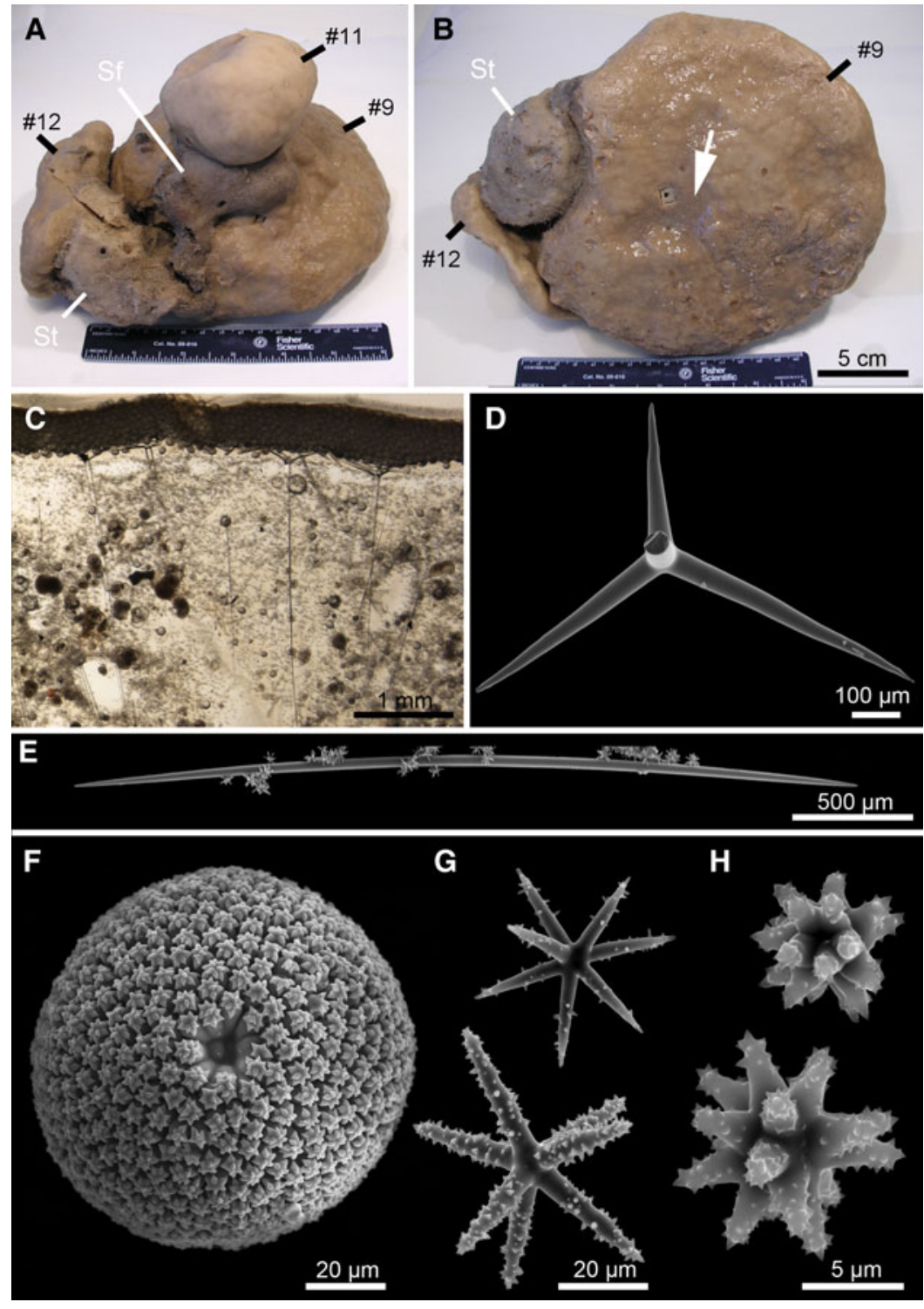

Fig. 3. Geodia atlantica (Stephens, 1915): (A) Specimens 50-373\#9 (ZMBN 105639), \#11 (ZMBN 105641), \#12 (ZMBN 105642) stick together along with specimens of Stryphnus fortis ZMBN 105640 (Sf) and Stelletta tuberosa ZMBN 105648 (St); (B) Another view of the same association, this time we see the uniporal oscules (arrow) of the largest G. atlantica specimen (ZMBN 105639); (C) Thick section (ZMBN 105639) showing the cortex (0.5 mm thick) essentially made of sterrasters, and underlying large orthotriaenes. Notice the abundant foraminifera in the choanosome; (D-H) SEM pictures of spicules (ZMBN 105641): (D) Cladome of an orthotriaene, rhabdome is broken; (E) Oxea and oxyasters; (F) Spherical sterraster with smooth rosettes; (G) Oxyasters I; (H) Spheroxyasters.

Geodia barretti Bowerbank, 1858

(Figures 2B \& 4)

\section{MATERIAL}

Four specimens, all from Station 70-385, $1650 \mathrm{~m}$ : ZMBN 105662, 105665, 105667, 105672.

\section{OUTER MORPHOLOGY AND SKELETON ORGANIZATION (FIGURE 4A, B)}

Massive subspherical white specimens. 105662 is the largest specimen, about $7 \mathrm{~cm}$ in diameter; 105672 is the smallest specimen, about $1 \mathrm{~cm}$ in diameter. All specimens have a single preoscule and cribriporal pores. 105665 is growing on Stelletta rhaphidiophora. Cortex 0.4-0.5 mm (105662). Thick sections were made for 105662, the skeleton organization is in accordance with previous observations (Cárdenas et al., 2013). Radial crystalline structures ('spherulites') observed in the sections, these structures are about $12-25 \mu \mathrm{m}$ in diameter with fan-shaped fibrous structures, with a rather smooth clear surface appearance. They are very abundant just below the cortex and around canals. They sometimes group in very confused masses.

SPICULES, ZMBN 105662 (FIGURE 4C-I)

Megascleres: (a) oxeas I, straight or bent, length: 10752530.3-4275 $\mu \mathrm{m}$; width: $12.5-39.2-62 \mu \mathrm{m}$. (b) oxeas II (=microxeas), straight or slightly bent, sometimes slightly centrotylote, length: 190-255.3-390 $\mu \mathrm{m}$; width: 6-8.8$11 \mu \mathrm{m}$. (c) dichotriaenes, rhabdome length: $2175-3375 \mu \mathrm{m}$ $(\mathrm{N}=2)$; width: $80-109.2-130 \mu \mathrm{m}$; protoclad length: $150-$ 211.6-310 $\mu \mathrm{m}$; deuteroclad length: $110-216.3-320 \mu \mathrm{m}$. (d) 

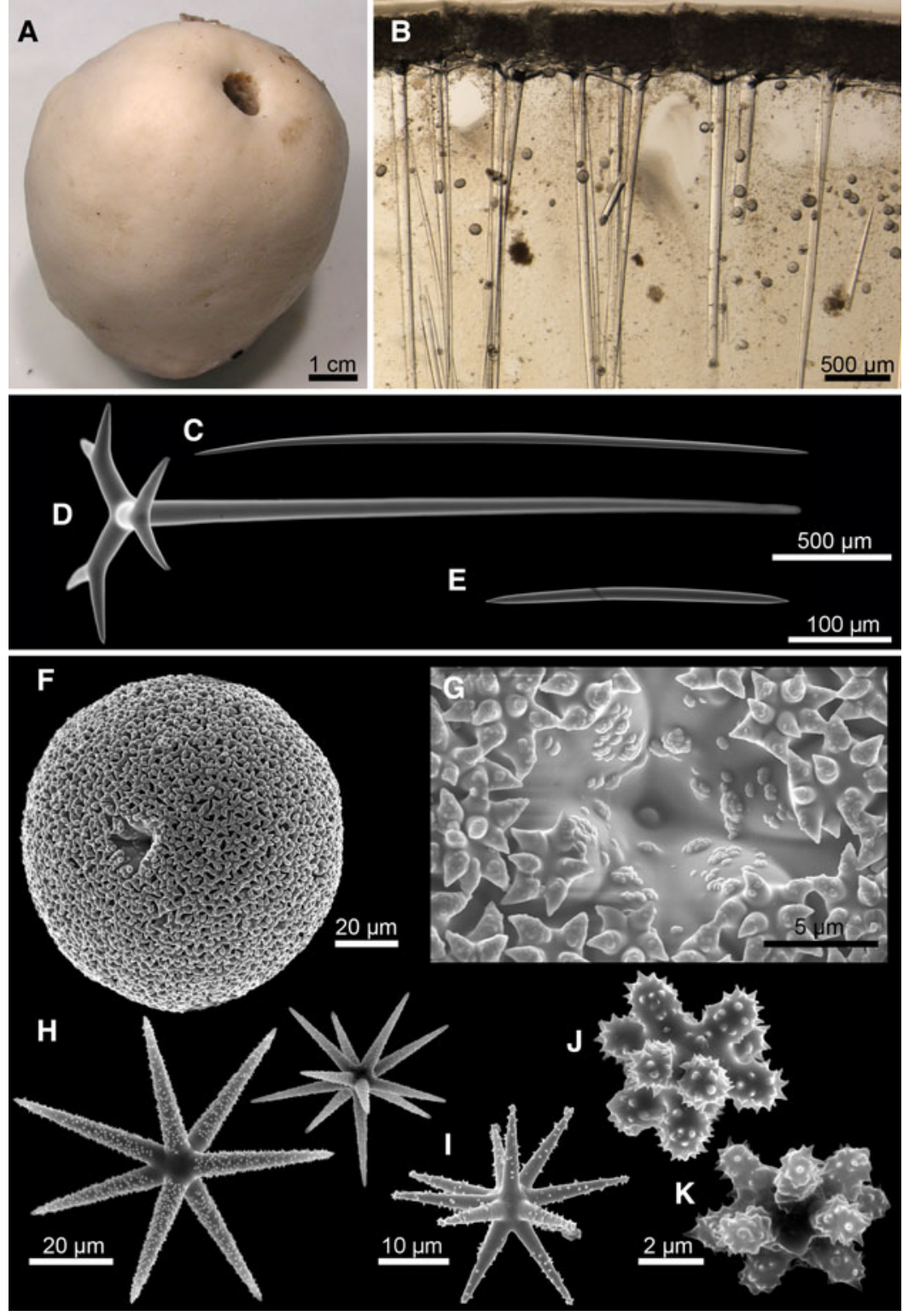

Fig. 4. Geodia barretti Bowerbank, 1858: (A) ZMBN 105662; (B) Thick section (ZMBN 105662) showing the cortex (0.5 mm thick) essentially made of sterrasters, and underlying large dichotriaenes; (C) Oxea I (ZMBN 105665); (D) Dichotriaenes (ZMBN 105665); (E) Oxea II (=microxea) (ZMBN 105665); (F) Sterraster (ZMBN 105662); (G) Close-up on the hilum of a sterraster (ZMBN 105662). Notice the warty rosettes; (H) Oxyasters I (ZMBN 105665); (I) Oxyasters I (ZMBN 105662); (J) Strongylaster (ZMBN 105662); (K) Strongylaster (ZMBN 105665).

meso/protriaenes, rare, rhabdome length: up to $2300 \mu \mathrm{m}$; width: 7.5-15 $\mu \mathrm{m}(\mathrm{N}=2)$; clad length: $60 \mu \mathrm{m}$; central clad length: $98 \mu \mathrm{m}$. Microscleres: (e) sterrasters, elongated, rosettes with warts, length: 96-104-114 $\mu \mathrm{m}$, width: 91-96.3$106 \mu \mathrm{m}$. (f) strongylasters, rough actines, $4-5.5-6.2 \mu \mathrm{m}$ in diameter. (g) oxyasters I, rough actines, diameter: $36.6-$ $56.8-78 \mu \mathrm{m}$. (i) oxyasters II, rough actines, diameter: $8-15.4-23.5 \mu \mathrm{m}$.

\section{BATHYMETRIC RANGE}

30-2000 m (Cárdenas et al., 2013).

\section{DISCUSSION}

Spicule measurements and external morphologies are perfectly in accordance with the description of the species (Cárdenas et al., 2013). A large category of oxyaster is present, as in other G. barretti which have been collected at depths deeper than $1000 \mathrm{~m}$ (Cárdenas \& Rapp, 2013; Cárdenas et al., 2013). The radial crystalline structures, thought to be calcareous, are common in many Tetillidae (e.g. Cárdenas et al., 2009) but to our knowledge this is the first time they are reported in Geodiidae.

\section{Geodia hentscheli Cárdenas et al., 2010}

(Figures $2 \mathrm{C}, 5$ \& 6 )

MATERIAL

One specimen from Station 72-386, 2534 m: ZMBN 105680.

\section{OUTER MORPHOLOGY AND SKELETON}

ORGANIZATION（FIGURE 5)

Massive subspherical whitish specimen, about $5 \mathrm{~cm}$ in diameter. Single preoscule and cribriporal pores. Cortex is 


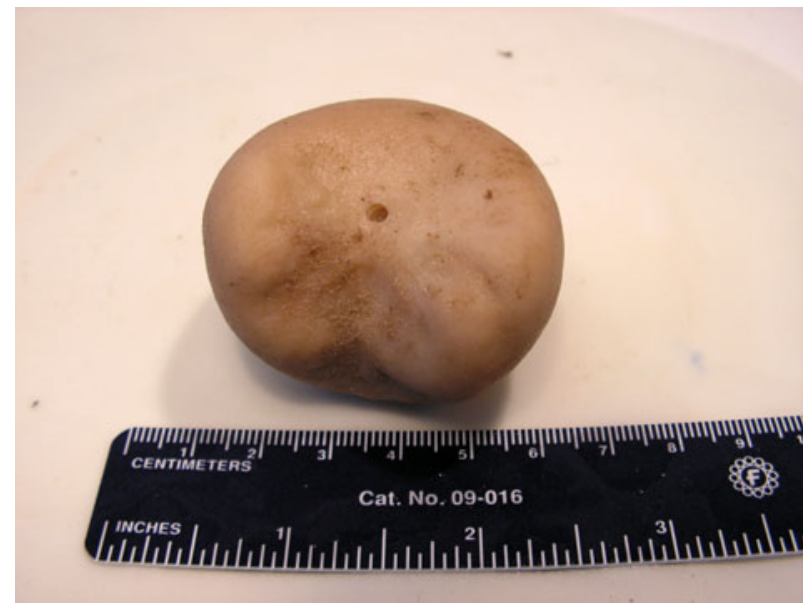

Fig. 5. Geodia hentscheli Cárdenas et al., 2010, ZMBN 105680.

0.5-0.6 mm thick, with a rather thick ectocortex (200 $\mu \mathrm{m})$. Skeleton organization is similar to that observed in other specimens (Cárdenas et al., 2013). Crystalline structures were observed, these structures are about $50-87 \mu \mathrm{m}$ in diameter with radial fibrous organization (very 'bushy' and confused appearance), and unclear borders. They are significantly larger and clearly different from the ones observed in G. barretti. They are present below the cortex and in the choanosome. Light brown granulated cells (or vacuoles?) are moderately present throughout the cortex as well as just below it; they are $10-20 \mu \mathrm{m}$ in diameter.

SPICULES, ZMBN 105680 (FIGURE 6A, B, D, E, G, I, J) Megascleres: (a) oxeas I, straight or bent, length: 1750-3709$4500 \mu \mathrm{m}$; width: $32-61.9-75 \mu \mathrm{m}$. (b) oxeas II (=microxeas), straight or slightly bent, sometimes slightly centrotylote, length: 102-325.1-632 $\mu \mathrm{m}$; width: 2.5-5.5-9 $\mu \mathrm{m}$. (c) dichotriaenes, rhabdome length: $1800-2442.5-3000 \mu \mathrm{m}$; width: 70-94.1-100 $\mu \mathrm{m}$; protoclad length: $130-162.4-200 \mu \mathrm{m}$ deuteroclad length: $100-207.5-260 \mu \mathrm{m}$. (d) mesoprotriaenes, rare, rhabdome length: 102-325.1-632 $\mu \mathrm{m}(\mathrm{N}=20)$; width 2.5-5.5-9 $\mu \mathrm{m} \quad(\mathrm{N}=20)$; clad length: $90-162.5-240 \mu \mathrm{m}$; central clad length: $17-86.1-260 \mu \mathrm{m}$. Microscleres: (e) sterrasters, elongated, length: 86-94.4-104 $\mu \mathrm{m}$, width: 75-86.5$92 \mu \mathrm{m}$. (f) strongylasters, rough actines with hook-like spines, 4-6.2-7.5 $\mu \mathrm{m}$ in diameter. (g) oxyasters, rough actines, diameter: $11-17.5-25 \mu \mathrm{m}$.

\section{BATHYMETRIC RANGE}

130-2534 m (Cárdenas et al., 2013; this study).

\section{DISCUSSION}

We identified the MAR-Eco specimen as G. hentscheli and not G. barretti because it has no oxyasters I, sterrasters with 'cauliflower' surface (Figure 6D, G), and many promesotriaenes. But this specimen is also slightly different from more northern specimens. The observed brown cells were not found in comparative material. The MAR-Eco specimen has elongated sterrasters which is unusual compared with more northern specimens. There are no irregular sterrasters, commonly found in Arctic specimens. The sterrasters are also fairly large for this species, but similar sizes were found in Davis Strait specimens. The microxeas are thinner: average of 5.5 vs averages of $8-16 \mu \mathrm{m}$ in comparative material from the NEA and NWA (Cárdenas et al., 2013; Table 4). Finally, the hook-like spines on the strongylasters had never been observed before (spines in the paratype ZMB Por 7551 strongylasters are simple), but SEM observations of more specimens is required to see how significant this character is. We reexamined thick sections made on comparative material (paratype ZMB Por 7551, Iceland specimen from Ingolf Expdt. Station 78, ZMBN 77925 from the Greenland Sea) to look for crystalline structures. Only ZMBN 77925 had such structures, but with a different morphology: smaller (32$50 \mu \mathrm{m})$, less confused, with fewer fibres and often with two opposite fans (unlike the MAR-Eco specimen, fixed in formalin, ZMBN 77925 had been directly fixed in ethanol 96\%).

Geodia cf. hentscheli Cárdenas et al., 2010

(Figures $2 \mathrm{C}, 6$ \& 7 )

\section{MATERIAL}

Seven specimens from Station 50-373, $2598 \mathrm{~m}$ : ZMBN 105632, 105634-36, 105638, 105645 (two specimens).

COMPARATIVE MATERIAL EXAMINED

ZMBN 25668, two wet specimens, Michael Sars 1910 Expedition, Station 53, 34.98333, -33.01667, 2615-2865 m, 08/06/1910, identified by E. Arnesen as 'Isops sp.?'; RMNH Por1458, Azores, 38.1, -24.81667, 2400-3100 m, CANCAP-V Expedition.

\section{OUTER MORPHOLOGY AND SKELETON}

ORGANIZATION (FIGURE 7)

Specimens are massive spherical sponges with a smooth regular surface and a brown colour (in ethanol). 105638 has an atypical oblongated shape. 105632 is attached to G. atlantica (105633). As in G. hentscheli, uniporal oscules are concentrated in the preoscule; every oscule is surrounded by ridges which can be very developed. The cribriporal pores are scattered over the rest of the body. The sterraster layer in 105645 is $0.8-1 \mathrm{~mm}$ thick with a poorly developed ectocortex (45 $\mu \mathrm{m}$ thick). Light brown granulated cells (or vacuoles) are moderately present throughout the cortex as well as below it; they are $10-20 \mu \mathrm{m}$ in diameter.

SPICULES, ZMBN 105645 (FIGURE 6C, F, H, K, L) Megascleres: (a) oxeas I, straight or slightly bent, length: 1750-3937.5-5000 $\mu \mathrm{m} \quad(\mathrm{N}=8)$; width: 22-44.6-55 $\mu \mathrm{m}$ $(\mathrm{N}=8)$. (b) oxeas II (=microxeas), straight or slightly bent, never centrotylote, length: $230-337.3-450 \mu \mathrm{m}$; width: $3-8.2-10 \mu \mathrm{m}$. (c) dichotriaenes (very few plagiotriaenes), rhabdome length: $1000-2495.3-3250 \mu \mathrm{m}(\mathrm{N}=21)$; width: 30-105.2-125 $\mu \mathrm{m}$; protoclad length: $140-174.8-250 \mu \mathrm{m}$; deuteroclad length: 190-240.2-300 $\mu \mathrm{m}$. Microscleres: (d) sterrasters, spherical, $102-114-120 \mu \mathrm{m}$ in diameter. (e) strongylasters, rough actines, $4-7.6-13 \mu \mathrm{m}$ in diameter. (f) oxyasters, rough actines, diameter: $20-44.2-85 \mu \mathrm{m}$.

\section{BATHYMETRIC RANGE}

$2400-3100 \mathrm{~m}$ (this study).

\section{DISCUSSION}

Differences with $G$. hentscheli are as follows. Oxeas II are never centrotylote. No mesoprotriaenes/anatriaenes were 

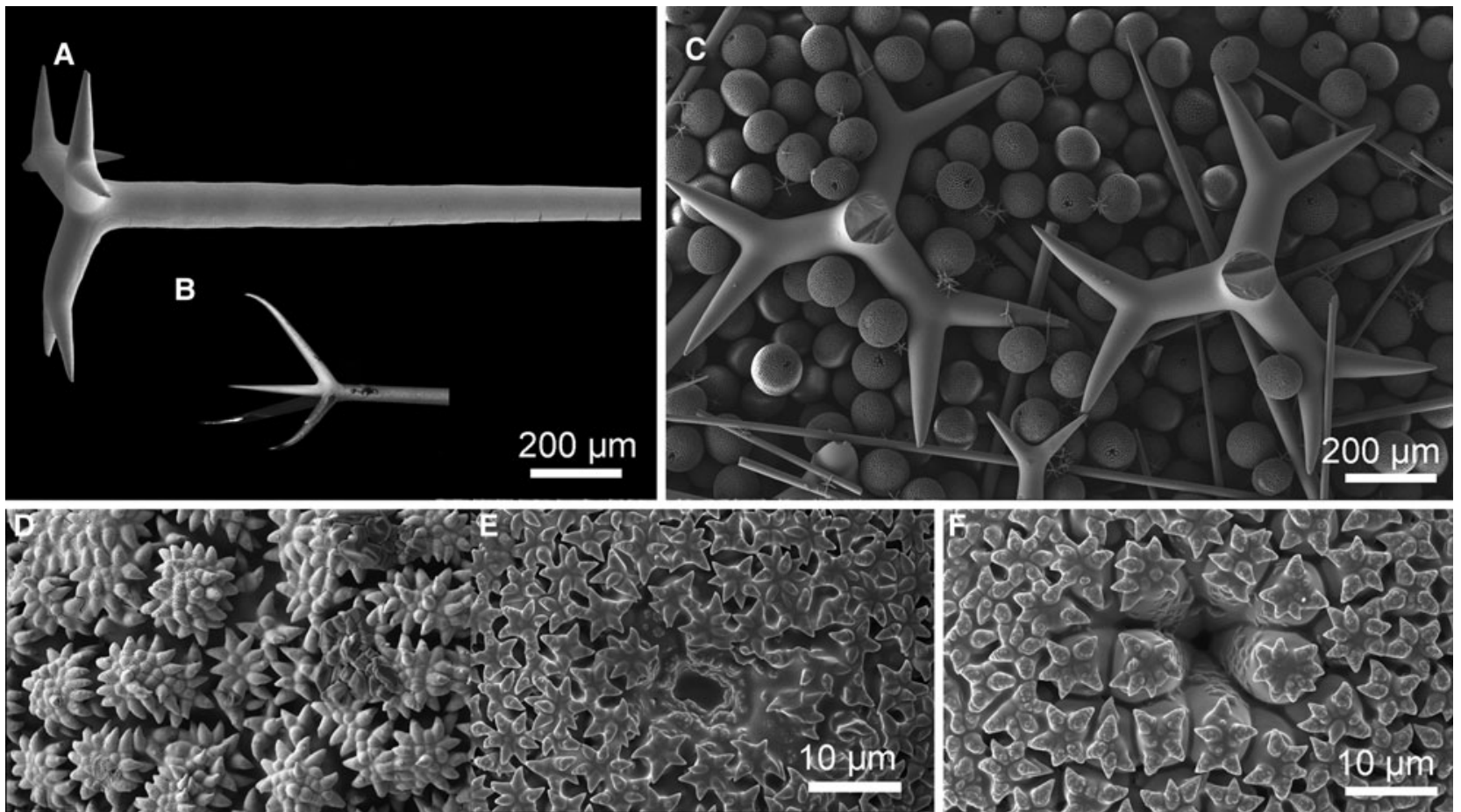

G
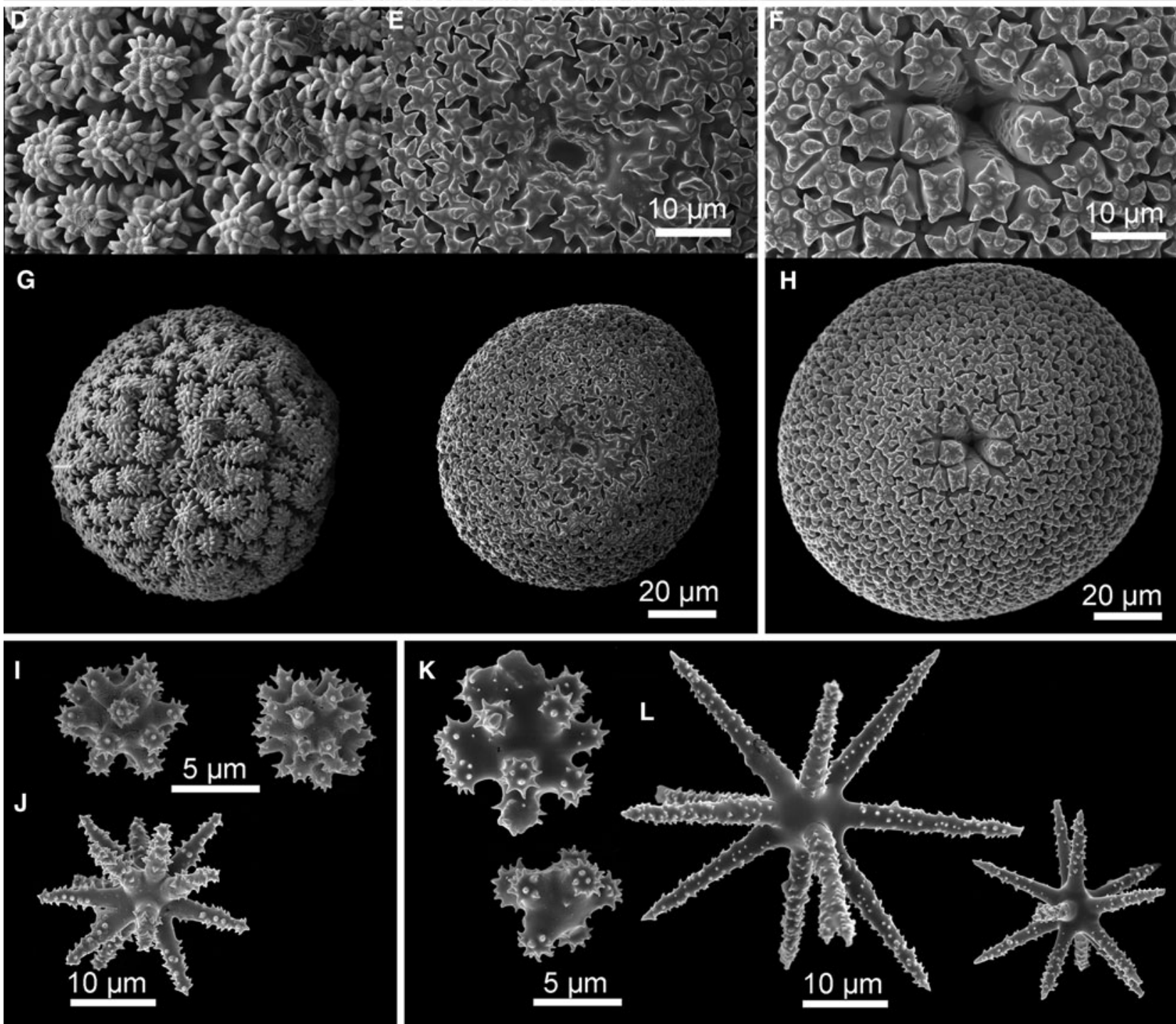

Fig. 6. Spicules of Geodia hentscheli Cárdenas et al., 2010, ZMBN 105680 and Geodia cf. hentscheli, specimen ZMBN 105645): (A) Dichotriaene (G. hentscheli); (B) Protriaene (G. hentscheli); (C) Dichotriaenes, small orthotriaene and sterrasters (G. cf. hentscheli); (D, E) Close-up of sterrasters showing the rosettes (G. hentscheli); (F) Close-up of sterrasters showing the rosettes (G. cf. hentscheli); $(\mathrm{G})$ sterrasters ( $G$. hentscheli); (H) sterraster (G. cf. hentscheli); (I) Strongylasters (G. hentscheli); (J) Oxyaster (G. hentscheli); (K) Strongylasters (G. cf. hentscheli); (L) Oxyasters (G. cf. hentscheli).

found but these are usually found in the fur of G. hentscheli and here no fur was observed, maybe due to the trawling collecting method. The sterrasters are spherical, never irregular or with a 'cauliflower' aspect (a common feature in
G. hentscheli). The dark brown colour seems to be the rule for this southern population whereas G. hentscheli is more often whitish or greyish; brown cells were observed only in the sections of $G$. hentscheli (105680), never in the $G$. 

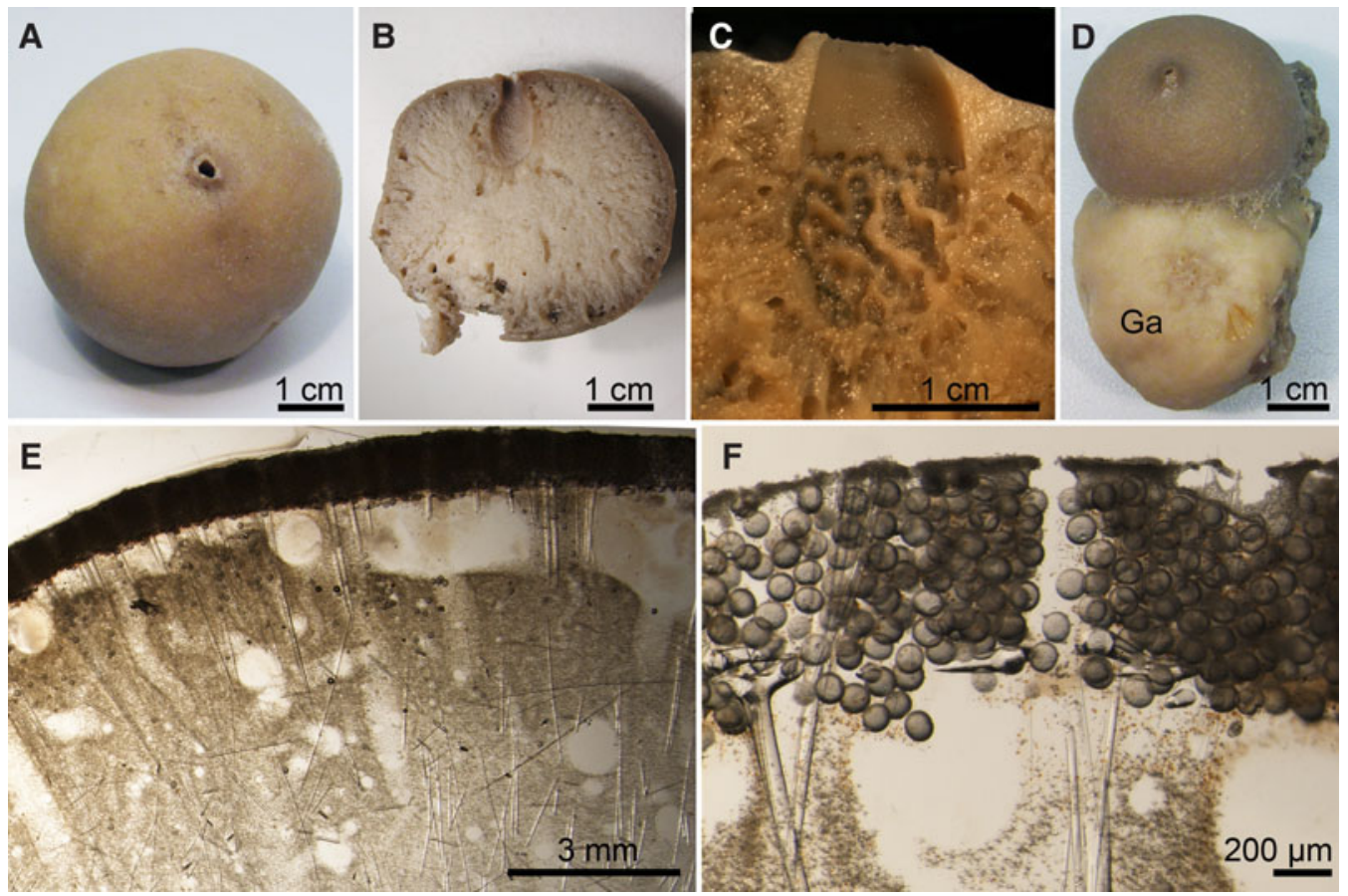

Fig. 7. Geodia cf. hentscheli Cárdenas et al., 2010: (A) One of the two specimens of ZMBN 105645, with a conspicuous preoscule opening; (B) Same specimen as in A, cut in half, showing preoscule; (C) Close-up of preoscule showing the ridges between the uniporal oscules. Note the thickened cortex above the preoscule opening; (D) ZMBN 105632, attached to a Geodia atlantica (Ga) (ZMBN 105633); (E) Thick section (ZMBN 105645); (F) Close-up of thick section showing the endocortex (o.8-1 mm thick) made of sterrasters, the ectocortex ( $45 \mu \mathrm{m}$ thick) made of strongylasters. Large dichotriaenes support the cortex.

hentscheli specimens revised by Cárdenas et al. (2013). No budding was observed ( $v$ s occasional budding in G. hentscheli) but again, we may have seen too few specimens. The oxyasters are also fairly large but these sizes are also found in $G$. hentscheli (Cárdenas et al., 2013). Likewise for the thicker cortex ( $1 \mathrm{~mm} v s 0.5 \mathrm{~mm}$ usually), it has been found in some G. hentscheli from Davis Strait (Cárdenas et al., 2013). SEM observations of the strongylasters show that they also have hook-like spines, such as the ones observed in 105680. All in all, this southern morphotype of $G$. hentscheli may represent a separate southern species, which diverged from its Arctic counterpart. But they seem closer morphologically to the MAR-Eco G. hentcheli 105680. Instead of creating a new species, we prefer to wait for genetic data to take taxonomic action. We have found two other specimens belonging to this southern morphotype in the Bergen Museum (ZMBN 25668) and in Naturalis (RMNH 1458): both were collected in the Azores area at $>2400 \mathrm{~m}$ depth.

\section{Geodia macandrewii Bowerbank, 1858}

(Figures 2D, 8 \& 9)

\section{MATERIAL}

Three specimens from Station 70-385, $1650 \mathrm{~m}$ : ZMBN 105661, 105666, 105669.

\section{OUTER MORPHOLOGY AND SKELETON}

ORGANIZATION (FIGURE 8A, B)

Massive subspherical, whitish specimens with smooth surfaces. Specimens 105661, 105666 and 105669 are respectively around $12 / 4 / 1.5 \mathrm{~cm}$ in diameter. Cortex of 105661 is $1 \mathrm{~mm}$ thick. Thick sections of 105661 were made, skeleton organization is similar to that observed in other specimens (Cárdenas et al., 2013) except that anatriaenes are more abundant below the cortex, associated with the orthotriaene bundles. Some sub-circular crystalline structures were observed, about $130-240 \mu \mathrm{m}$ in diameter with radial fibrous organization (very 'bushy' and confused appearance), and unclear borders. They are similar but larger than the ones observed in G. barretti, and are present below the cortex and in the choanosome.

SPICULES, ZMBN 105661 (FIGURES 8C, G \& 9) Megascleres: (a) oxeas I, straight or bent, length: 40005280.5-7000 $\mu \mathrm{m} \quad(\mathrm{N}=10)$; width: $25-48.7-60 \mu \mathrm{m} \quad(\mathrm{N}=$ 10). (b) oxeas II (=microxeas), straight or slightly bent, not centrotylote, length: 250-335.5-485 $\mu \mathrm{m}$; width: 3.5-8.4$12.5 \mu \mathrm{m}$. (c) orthotriaenes, rhabdome length: $1100-4762.5-$ $6550 \mu \mathrm{m}(\mathrm{N}=10)$; width: $20-82.8-105 \mu \mathrm{m}$; clad length: $300-739-1042 \mu \mathrm{m}$. (d) anatriaenes, very common, with sometimes a swelling or spine on top of the cladome

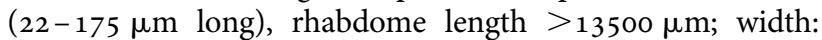
3-19.7-40 $\mu \mathrm{m}$; clad length: 15-137.5-280 $\mu \mathrm{m}$. (e) promesotriaene, rhabdome length $>5700 \mu \mathrm{m}$; width: $10-32-$ $45 \mu \mathrm{m}(\mathrm{N}=10)$; clad length: 47-237.4-500 $\mu \mathrm{m}(\mathrm{N}=9)$; central clad length: 55-151.2-240 $(\mathrm{N}=4)$. Microscleres: (f) sterrasters, spherical, warty rosettes, $125-155.2-180 \mu \mathrm{m}$ in diameter. (g) spheroxyasters, rough essentially at the tip of actines, $5-10-15 \mu \mathrm{m}$ in diameter. (h) oxyasters, rough essentially at the tip of actines, diameter: $10-22.4-47 \mu \mathrm{m}$.

BATHYMETRIC RANGE

157-1900 m (Cárdenas et al., 2013). 

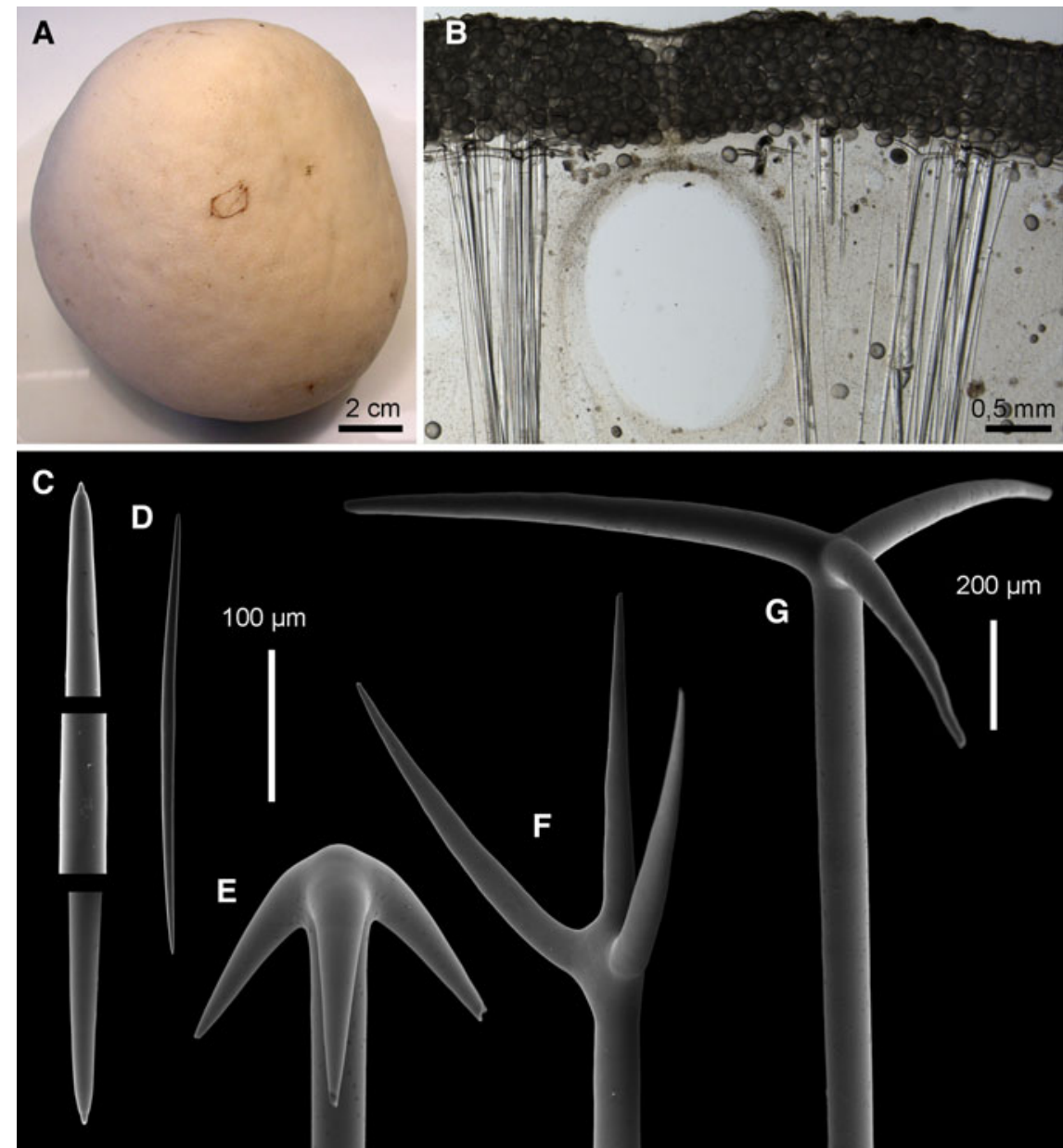

Fig. 8. Geodia macandrewii Bowerbank, 1858: (A) ZMBN 105661; (B) Thick section (ZMBN 105661), notice the bundles of orthotriaenes and anatriaenes under the cortex; (C-G) SEM pictures of spicules (ZMBN 105666): (C) Oxea I; (D) Oxea II (=microxea); (E) Anatriaene; (F) Protriaene; (G) Orthotriaene. (C-F: same scale).
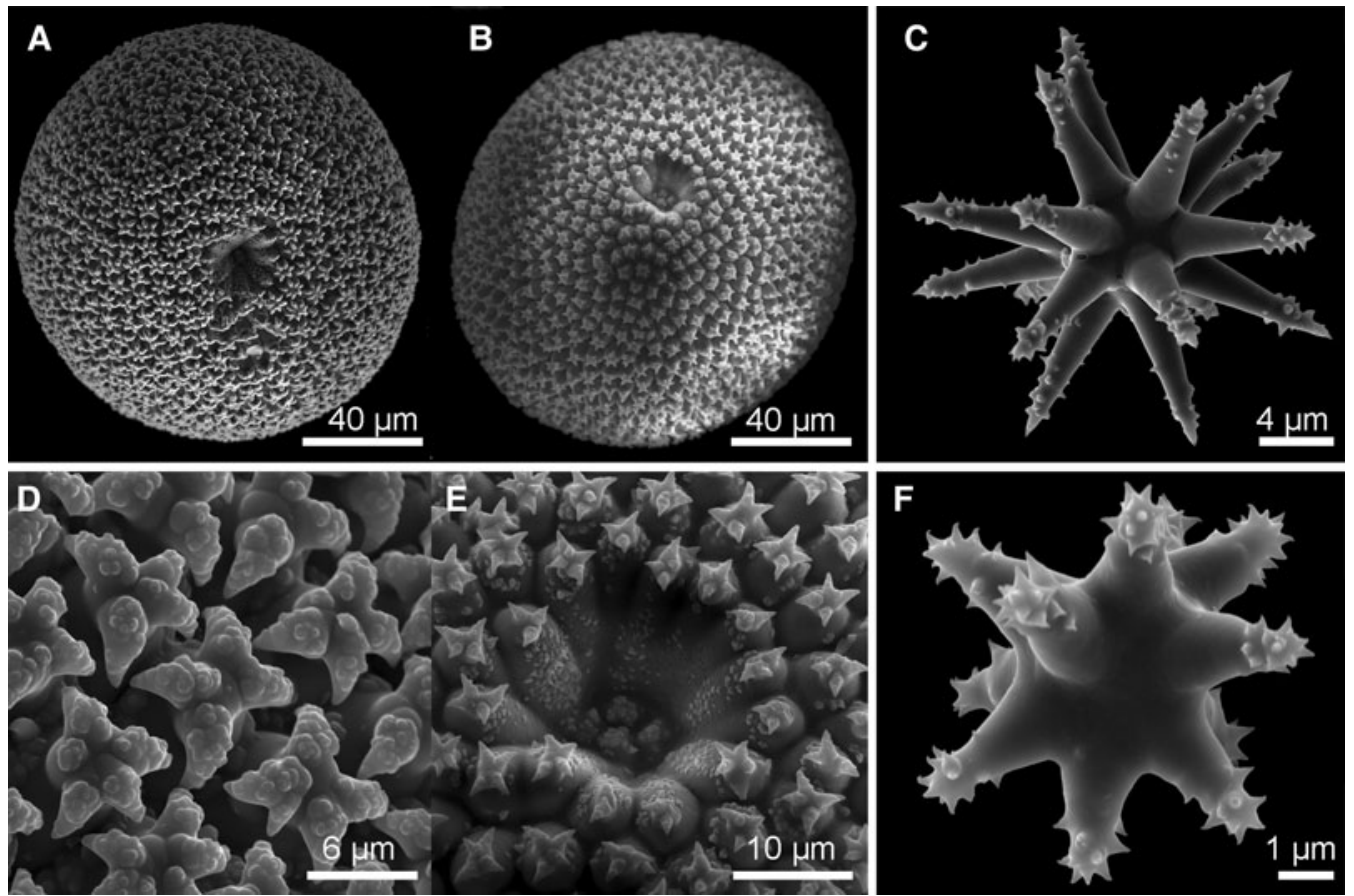

Fig. 9. Microscleres of Geodia macandrewii Bowerbank, 1858, ZMBN 105666: (A) Sterraster with fully developed warty rosettes; (B) Sterraster with developing rosettes; (C) Oxyasters; (D) Close-up of the sterraster in A showing the fully developed warty rosettes; (E) Close-up of the sterraster in B showing the hilum and the developing rosettes; (F) Spheroxyasters. 


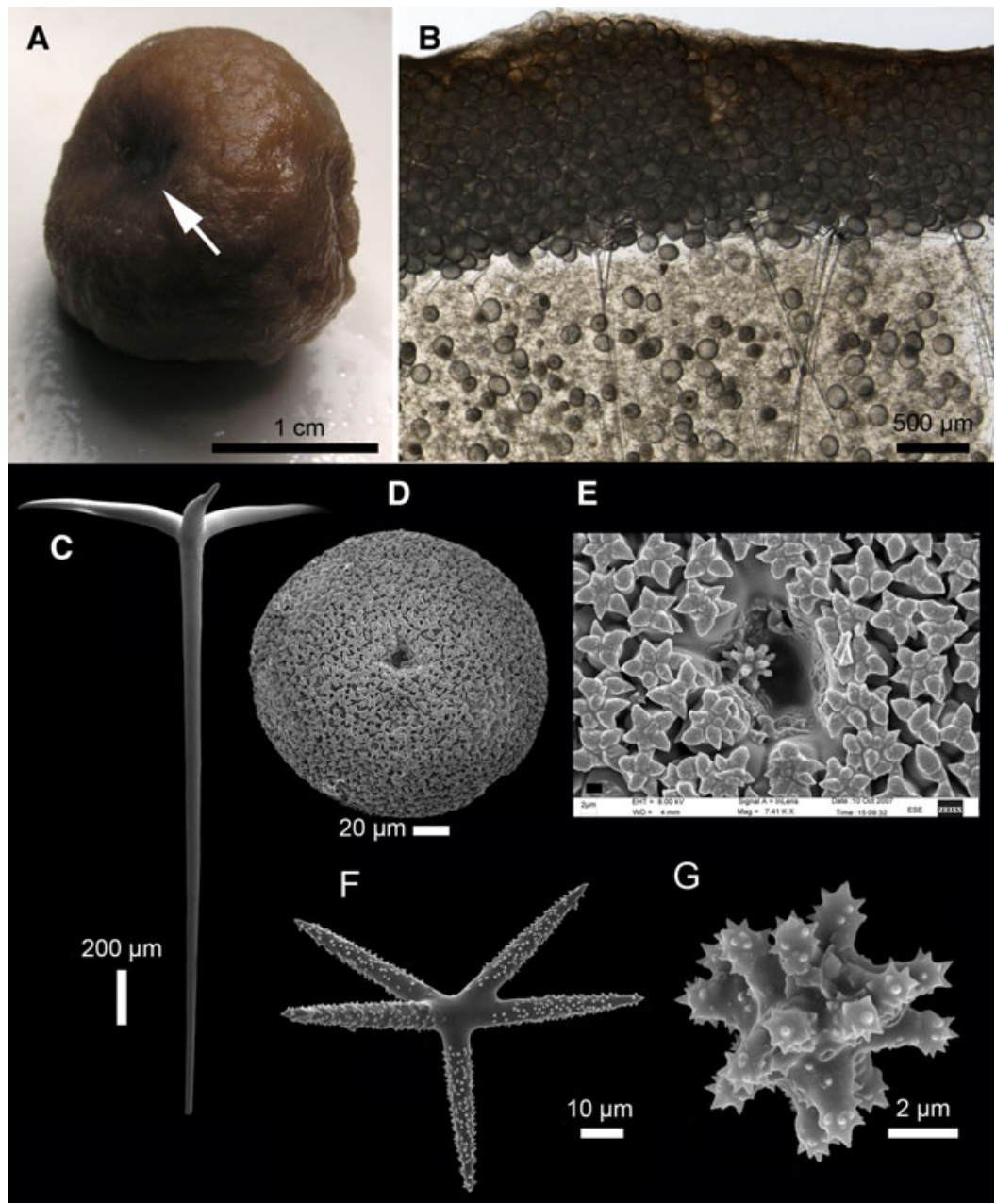

Fig. 10. Geodia megastrella Carter, 1876, ZMBN 105646: (A) Specimen, arrow points at preoscule; (B) Thick section; (C) Orthotriaene; (D) Sterraster; (E) Close-up of sterraster showing hilum and warty rosettes; (F) Oxyaster I; (G) Strongylaster.

\section{DISCUSSION}

The large size of the oxyasters is typical of individuals living deeper than $1000 \mathrm{~m}$ (Cárdenas et al., 2013). The sterrasters measured in 105661 are the smallest sized ones ever found for this species and specimens 105666 and 105669 also had sterrasters in similar size ranges: G. macandrewii sterrasters are usually more than $200 \mu \mathrm{m}$ in diameter (Cárdenas et al., 2013). We reexamined thick sections of ZMBN 77924 (G. macandrewii from Korsfjord, Norway, fixed in ethanol $70 \%)$ but could not find any crystalline structures.

\section{Geodia megastrella Carter, 1876}

(Figure 10)

\section{MATERIAL}

One specimen from Station 50-373, 2600 m: ZMBN 105646.

\section{OUTER MORPHOLOGY AND SKELETON}

ORGANIZATION (FIGURE 1OA, B)

Subspherical specimen, $2 \mathrm{~cm}$ in diameter. Colour in ethanol is brown. A single small preoscule on the top surface, cribriporal pores all over the rest of the surface. The cortex is $1.2-1.7 \mathrm{~mm}$ thick, very tough, and supported by triaenes and oxeas which form a $3.5 \mathrm{~mm}$ thick layer; below, oxeas occur in confusion. Oxyasters I can be found in high abundance in the choanosome. Microxeas can be found in the ectocortex and the choanosome. Large granulated cells about $25 \mu \mathrm{m}$ in size can be found in the upper part of the endocortex, they contain many brown vacuoles inside. Some crystalline structures were observed in the choanosome, about $30-87 \mu \mathrm{m}$ in diameter with clear radial fibrous organization and 'hairy' border. They are of similar size and shape to the ones observed in G. hentscheli (105680) but the fibres seem to be thinner and less confused.

SPICULES, ZMBN 105646 (FIGURE 1OC-G)

Megascleres: (a) oxeas I, bent, some slightly centrotylote, length: 840-1671.9-2750 $\mu \mathrm{m}(\mathrm{N}=13)$; width: 15-26.3$35 \mu \mathrm{m}(\mathrm{N}=13)$. (b) oxeas II (=microxeas), straight, a few are centrotylote, length: $195-290.2-350 \mu \mathrm{m}$; width: 4-7.6$11 \mu \mathrm{m}$. (c) orthotriaenes, and very few dichotriaenes, rhabdome length: 1750-2193.7-3000 $\mu \mathrm{m}(\mathrm{N}=4)$; width: 40-55.3-70 $\mathrm{m}(\mathrm{N}=14)$; protoclad length: $120 \mu \mathrm{m}(\mathrm{N}=$ 1); deuteroclad length: $220 \mu \mathrm{m}(\mathrm{N}=1)$. (d) promesotriaene, only one found, rhabdome width: $20 \mu \mathrm{m}$; clad: $110 \mu \mathrm{m}$; central clad: $300 \mu \mathrm{m}$. Microscleres: (e) sterrasters, spherical, $150-163.5-190 \mu \mathrm{m}$ in diameter, hilum $\sim 10 \mu \mathrm{m}$ in diameter, 

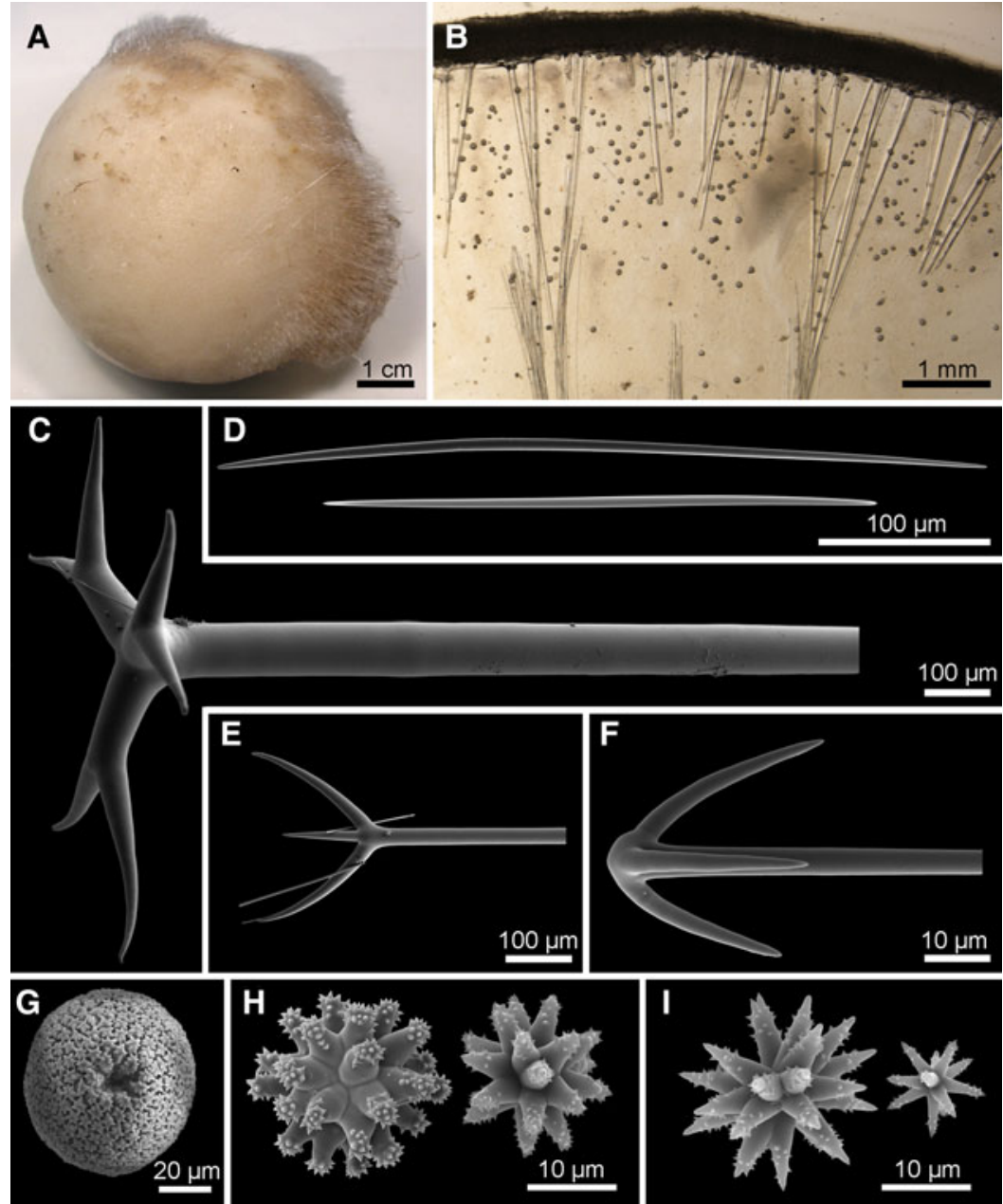

Fig. 11. Geodia nodastrella Carter, 1876, ZMBN 105644: (A) Specimen; (B) Thick section; (C) Dichotriaene; (D) Oxeas II (=microxeas); (E) Protriaene; (F) Anatriaene; (G) Sterraster; (H) Spherasters; (I) Oxyasters.

warty rosettes. (f) strongylasters, rough actines, 5.5-8.5$12 \mu \mathrm{m}$ in diameter. (g) oxyasters I, $3-8$ rough actines, diameter: $47-93.3-150 \mu \mathrm{m}$. (h) oxyasters II, 7-9 thin rough actines, diameter: $19-28-42 \mu \mathrm{m}$.

\section{BATHYMETRIC RANGE}

200-2600 m (Topsent, 1911; this study).

\section{DISCUSSION}

The external morphology of the MAR-Eco specimen from Station 50 (north of the Azores) is very similar to the specimen described and illustrated by Topsent (1928) from Madeira at $2380 \mathrm{~m}$, and the specimen identified as 'Sidonops sp.?' by Arnesen (1920) from the Ibero-Moroccan Gulf at $1215 \mathrm{~m}$ (ZMBN 25652, re-examined for this study). A still photograph from a video by the manned-submersible MIR 1 above $1700 \mathrm{~m}$ depth in the CGFZ (Felley et al., 2008, Supplementary material) shows globular sponges with a single preoscule that look very much like $G$. megastrella, so this species may also be present in the CGFZ (dive coordinates $52^{\circ} 58^{\prime} \mathrm{N} 35^{\circ} 01^{\prime} \mathrm{W}$ ). No distribution map was made for this species found between Ireland and the Azores in the NEA and between the New England seamounts and Florida in the NWA (P. Cárdenas, unpublished results) since we suspect it to be a species complex (Cárdenas et al., 2011) which needs to be properly revised before anything can be said about its biogeography. This is the first time that microxeas are observed to be occasionally centrotylote in G. megastrella. Occasional centrotylote microxeas may be a synapomorphy of the species belonging to the Depressiogeodia clade (G. barretti, $G$. hentscheli and G. megastrella complex) even though it has also been observed in G. macandrewii, albeit more rarely (Cárdenas et al., 2013).

\section{Geodia nodastrella Carter, 1876 \\ (Figures 2E \& 11, Table 2)}

\section{MATERIAL}

One specimen from Station 50-373, $2600 \mathrm{~m}$ : ZMBN 105644.

\section{COMPARATIVE MATERIAL EXAMINED}

Geodia nodastrella, MOM-INV-22575 (04-0118) (wet specimen) and MNHN-DT846 (slide), Station 198 (1888), $800 \mathrm{~m}$, $38.44028,-30.98611$, original det. as G. barretti var. nodastrella (Topsent, 1892, p. 48); MNHN-DT845, two slides for two different specimens from Station 882 (one of the slides has written 'spécimen monstrueux' on it because the spicules 


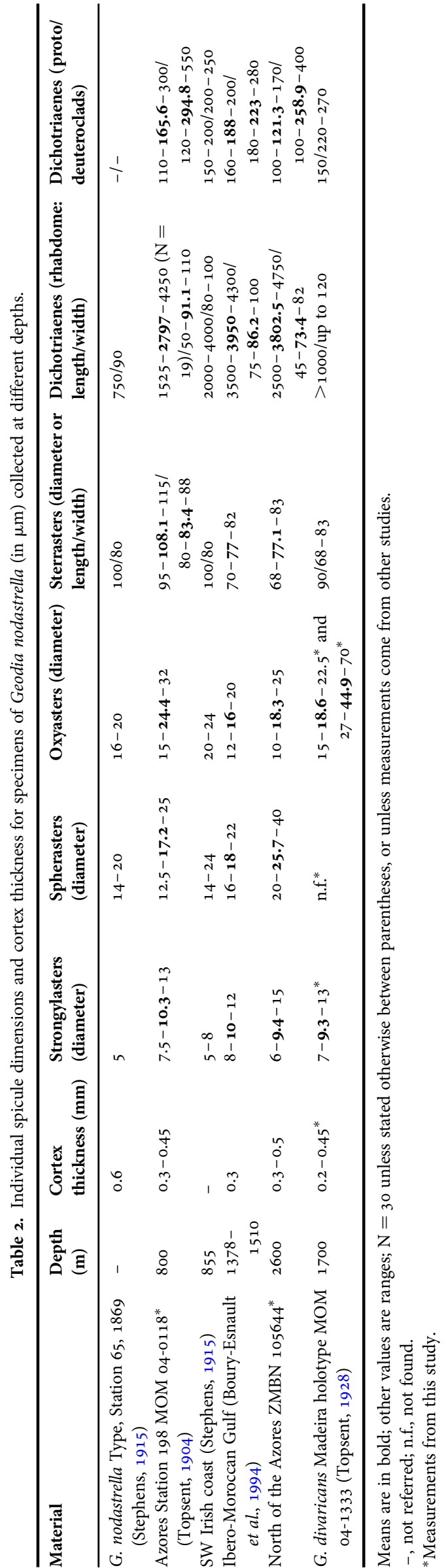

are atypical, therefore the identification of this specimen remains doubtful), $38.06111,-28.57917,98 \mathrm{~m}$, original det. as G. eosaster (Topsent, 1904, p. 67); MNHN-DT844 (slide), Station $899,37.95,-29.24583,200 \mathrm{~m}$, original det. as G. eosaster (Topsent, 1904); MNHN-DT1090, off Morocco, Station $1116,31.725,-10.77917,2165 \mathrm{~m}$, det. by Topsent (1928); MNHN-DT1259, West of Flores, Azores, Station 2210, $39.41667,-31.375,1229 \mathrm{~m}$, det. by Topsent (1928); MNHN Balgim campaign (Boury-Esnault et al., 1994), CP63-E2 (three specimens), 35.50167, -7.70028, $1510 \mathrm{~m}, \mathrm{CP} 98-\mathrm{E}_{41}$, $34.46861,-7.68556,1747 \mathrm{~m}$. ZMBN 25660 (two specimens), Station 24, 35.56667, $-7.58333,1615 \mathrm{~m}$, original det. as 'Sidonops sp.?' (Arnesen, 1920), PC678-679, AVILES 0511, DRo3030511, 43.91862, $-5.7658,799 \mathrm{~m}$. BANGAL 0710, DRo6110810, 42.66298, -11.94938, $920 \mathrm{~m}$; DRo3090810, 42.7271, $-11.83727, \quad 797 \mathrm{~m}$; DRo1080810, 42.6811, -11.61075, $999 \mathrm{~m}$; DRo7120810, 42.81035, -11.72252, 999 m. ZMAPOR 20372, Mingulay Reef, field\#DR63/20, $56.80663,-7.43173,151-159 \mathrm{~m}$, det. by $\mathrm{P}$. Cárdenas. UPSZMC-BIO, NEREIDA 2009-2010: UPSZMC 78295, DR7, 48.25630, -44.03084, $1339 \mathrm{~m}$; DR18, 47.26186, -43.53101, $1079 \mathrm{~m} ; \quad \mathrm{DR} 19,47.16431,-43.476328,1137 \mathrm{~m} ; \quad \mathrm{DR} 20$, 47.07224, - 43.44914, $1122 \mathrm{~m}$; DR21, 46.84606, - 43.71764, $870 \mathrm{~m}$; DR22, 46.84001, -43.64039, $956 \mathrm{~m}$; DR23, 46.77485, $-43.86510,1127 \mathrm{~m}$; DR24, 46.69422, $-43.96859,1104 \mathrm{~m}$; UPSZMC 78296, DR64, 46.42378, -44.84577, $1091 \mathrm{~m}$; UPSZMC 78294, DR70, 45.88667, -46.55616, $916 \mathrm{~m}$. Geodia divaricans, holotype, MOM-INV-22535 (04-1333) (wet specimen) and MNHN DT-1299 (slide), Madeira, Station 3113, 32.57917, $-17.09167,1700 \mathrm{~m}$.

\section{OUTER MORPHOLOGY AND SKELETON}

ORGANIZATION (FIGURE 11A, B)

Massive spherical specimen $(6 \mathrm{~cm}$ in diameter), white in ethanol, fairly hispid on one side, not compressible. Regular surface with no obvious large openings but small cribriporal pores and oscules are present. Cortex is $0.5-0.6 \mathrm{~mm}$ thick and fairly easy to cut. The positions of the different euasters are clear on the thick sections. Ectocortex is $200-250 \mu \mathrm{m}$ thick, with sub-radial microxeas, numerous strongylasters (especially packed in the ectosome) and few spherasters. The fibrous endocortex is $500-600 \mu \mathrm{m}$ and packed with sterrasters; it is supported by large dichotriaenes. Protriaenes are crossing the cortex with their cladomes beyond the surface. In the choanosome, there are sparse oxyasters. Some irregular crystalline structures were observed in the choanosome, about $87-175 \mu \mathrm{m}$ in length with radial fibrous organization. They are similar to the ones observed in G. macandrewii but more irregular in shape and less 'dirty'.

SPICULES, ZMBN 105644 (FIGURE 11C-I)

Megascleres: (a) oxeas I, straight or fairly bent, sometimes somewhat vermiform, length: $2050-3203-4100 \mu \mathrm{m}(\mathrm{N}=$ 20); width: $25-32.7-38 \mu \mathrm{m}(\mathrm{N}=20)$. (b) oxeas II (=microxeas), straight or slightly bent, not centrotylote, length: $260-370.7-$ $500 \mu \mathrm{m}$; width: 4-6.2-8 $\mu \mathrm{m}$. (c) dichotriaenes, straight rhabdome, deuteroclads are often curved, rhabdome length: 2500-3802.5-4750 $\mu \mathrm{m}$; width: 45-73.4-82 $\mu \mathrm{m}$; protoclad length: $100-121.3-170 \mu \mathrm{m}$; deuteroclad length: $100-258.9-$ $400 \mu \mathrm{m}$. (d) anatriaenes, rhabdome length $>8250 \mu \mathrm{m}$; width: 3-16.0-35 $\mu \mathrm{m}$; clad length: $15-137.5-280 \mu \mathrm{m}$. (e) protriaenes and promesotriaenes, rhabdome length $>6500 \mu \mathrm{m}$; width: 
14-32.7-45 $\mu \mathrm{m} \quad(\mathrm{N}=23)$; clad length: $150-296.3-430 \mu \mathrm{m}$ $(\mathrm{N}=23)$; central clad length: 160-232.8-310 $(\mathrm{N}=7)$. Microscleres: (f) sterrasters, spherical, rosettes with warts, 68$77.1-83 \mu \mathrm{m}$ in diameter. (g) strongylasters, spiny, 6-9.4$15 \mu \mathrm{m}$ in diameter. (h) spherasters, blunt to truncated actines with spiny tips, $20-25.7-40 \mu \mathrm{m}$ in diameter. (i) oxyasters, usually with many thin actines, spiny, 10-18.3-25 $\mu \mathrm{m}$ in diameter.

\section{BATHYMETRIC RANGE}

98-2600 m (Topsent, 1904; this study).

\section{DISCUSSION}

This study is an opportunity to revise the morphology of this poorly known, albeit fairly common, Lusitanian species. Many specimens photographed just after collection during the NEREIDA campaign (courtesy of F. J. Murillo) and the BANGAL cruise (courtesy of P. Rios) show that the natural external colour of this species is whitish to light brown. This species always has dichotriaenes, which often have 'wavy' deuteroclads. As previously observed by Topsent (1904) and Stephens (1915), the euasters have variable morphologies. The ectcortical strongylasters often have an inflated centrum (spherostrongylaster) and are then difficult to separate from the smallest spherasters; in other specimens they also sometimes have long actines with inflated tips as in tylasters (MNHN-DT1090, NEREIDA DR07-043b). The spherasters are most often fairly spherical but, sometimes, they are less inflated; their actine tips are also variable with sometimes blunt truncated tips, and sometimes sharp conical tips. As for the choanosomal oxyasters they sometimes have thin long actines, and sometimes wider conical actines. For instance, in the specimen from the Azores (Station 198) studied by Topsent $(1892,1904)$ and in the Balgim specimens, we found both morphologies of oxyasters.

Stephens (1915) states that the spherasters are placed just below the cortex but our sections of the MAR-Eco specimen and MOM 04-0118 clearly show that spherasters are present in the ectocortex as well (i.e. above the sterraster layer). Actually, in the MAR-Eco specimen, they are only present in the ectocortex. Topsent (1904) notices that spherasters can become rare. We also observed this, and even found specimens where the characteristic spherasters were missing (e.g. BANGAL PC581, PC579, ZMBN 25660). In these specimens without spherasters, we did find many oxyspherasters but it is unclear if they are deflated spherasters or inflated oxyasters (since spherasters and oxyasters essentially have similar sizes).

The size of the oxyasters is also very variable, they can vary from 20-24 $\mu \mathrm{m}$ (Stephens, 1915) to 30-40 $\mu \mathrm{m}$ (MNHN-DT844) as in the MAR-Eco specimen and even up to $72 \mu \mathrm{m}$ (BANGAL PC579, ZMBN 25660). The continuum of sizes makes it impossible to delimitate two size categories. The important variation in size of the choanosomal oxyasters has already been observed in all Atlantic boreo-arctic Geodia and may be related to the depth and/or the silica concentration (Cárdenas \& Rapp, 2013; Cárdenas et al., 2013). We should stress here that specimens without spherasters and/or large oxyasters were confirmed to be $G$. nodastrella with external morphology, other spicules, as well as with molecular data ( $P$. Cárdenas, unpublished results). We also noticed that the MAR-Eco specimen has spherical sterrasters, whereas they can be ellipsoid in the comparative material (e.g. BANGAL PC 581 , MNHN-DT846). The size of the sterrasters varied between 68 and $115 \mu \mathrm{m}$ which is in the same range as most boreo-arctic Geodia, except for the very large sterrasters of G. macandrewii (Cárdenas et al., 2013). Finally, another variation concerned the microxeas found in the ectocortex: the MAR-Eco specimen has fairly longer microxeas $(260-500 \mu \mathrm{m})$ than in previous measurements $(167-350 \mu \mathrm{m})$ (Table 2$)$.

With all these variations in mind, we re-examined the holotype of Geodia barretti divaricans from Madeira (MOM-INV-0022282, wet specimen and MNHN DT-1299, spicule preparation). The wet specimen is a small hispid fragment attached to coral, it is the only specimen known of this species. We made thick sections from the type and measured euasters (Table 2). It occurred to us that the spicule repertoire was very close to that of $G$. nodastrella. The oxyasters can be found in various sizes, the smaller ones $(15-22.5 \mu \mathrm{m})$ can be found just below the cortex and the larger ones $(27-70 \mu \mathrm{m})$ are very numerous throughout the choanosome. Topsent (1928) surprisingly overlooked the small oxyaster sizes, even though we found some on Topsent's slide (MNHN-DT1299). The small oxyasters with an inflated centrum and spiny actines look similar to the ones we observed in specimens of G. nodastrella from Galicia (BANGAL). The length of the microxeas in G. divaricans $(210-525 \mu \mathrm{m})$ are actually closer to the ones from our MAR-Eco specimen (260$500 \mu \mathrm{m})$. Geodia divaricans was also characterized by inflated rhabdomes of the dichotriaenes and rare flattened anatriaenes (Topsent, 1928). However, slight rhabdome swellings were also observed in the dichotriaenes of $G$. nodastrella from Galicia and more or less flattened anatriaenes (although not as flattened as in G. divaricans) were also observed in the Irish specimens (Stephens, 1915). Finally, the absence of spherasters as discussed previously is possible in G. nodastrella. So, in our opinion, no specific cortical or spicule characters really remain to keep the valid status of $G$. divaricans. Therefore, we formally propose that G. divaricans Topsent, 1928 is a junior synonym of G. nodastrella Carter, 1876. The G. nodastrella recorded by Burton (1934) in Greenland has been re-identified as $G$. hentscheli (Cárdenas et al., 2013). We also re-examined the two specimens (ZMBN 25660) identified as 'Sidonops sp.?' by Arnesen (1920); these were collected quite near the Balgim CP63 station where G. nodastrella was reported. Their external morphology (large spherical sponges with cribriporal pores/ oscules) clearly matches that of G. nodastrella and their spicules match those of $G$. divaricans (no spherasters, very large oxyasters). The other sponge identified as 'Sidonops sp.?' (ZMBN 25652 ) is in fact G. megastrella (see above).

\section{Geodia phlegraei (Sollas, 1880)} (Figures $2 \mathrm{~F} \& 12$ )

\section{MATERIAL}

Five specimens from Station 72-386, $2534 \mathrm{~m}$ : ZMBN 105675-78, 105681.

\section{OUTER MORPHOLOGY AND SKELETON}

ORGANIZATION (FIGURE 12A-E)

Specimens are spherical to subspherical sponges between 1.5 and $6 \mathrm{~cm}$ in diameter, with remains of hispidity on the sides, which are purple (possibly coloured by the encrusting sponge Hexadella dedritifera Topsent, 1913). 105678 has an Hexactinellida growing on it (Figure 12B). Oscules and pores are uniporal. Thick sections of 105675 were made. Cortex is 

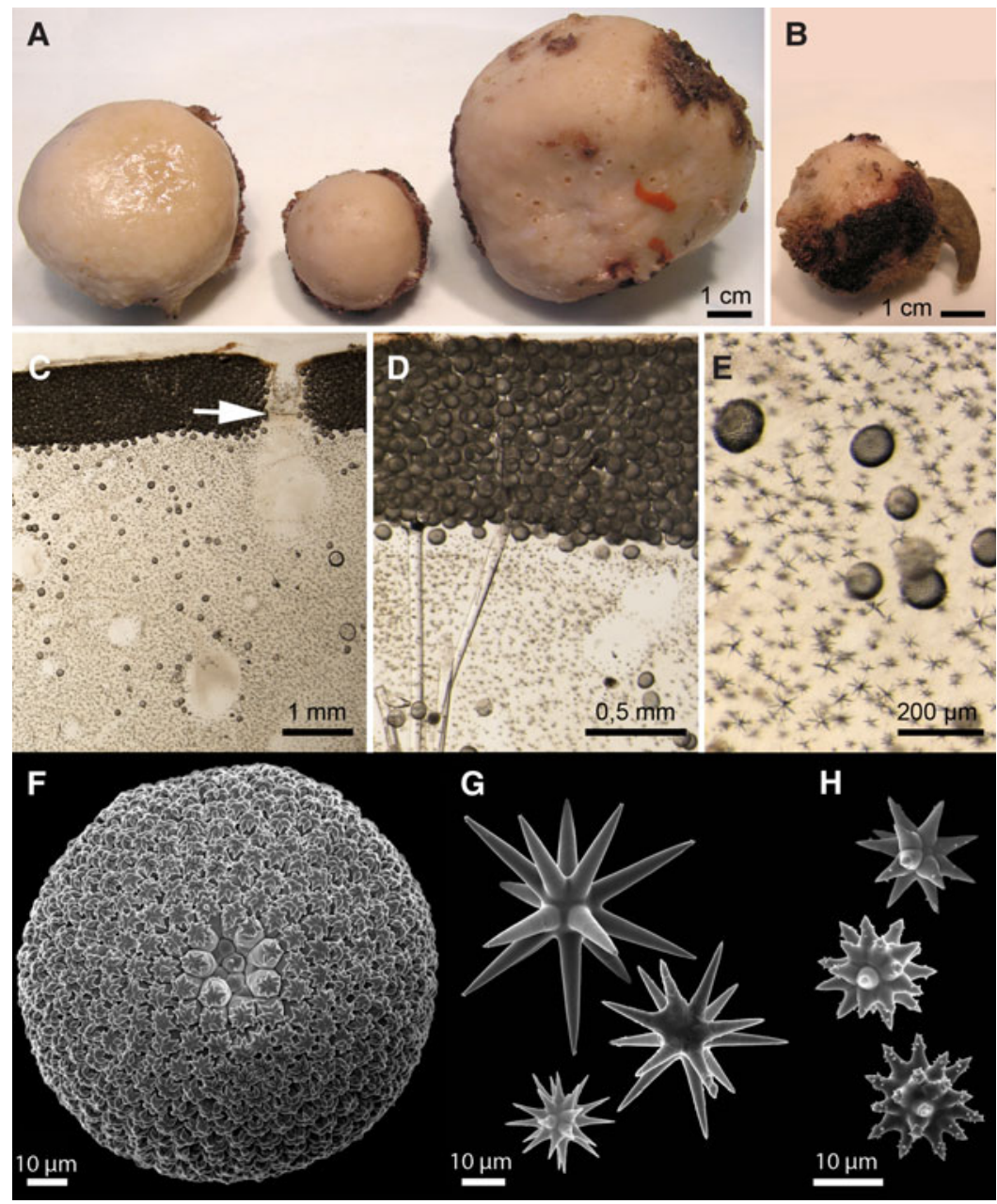

G

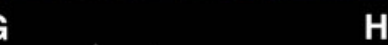

Fig. 12. Geodia phlegraei (Sollas, 1880): (A) From left to right, ZMBN 105675-77. Conspicuous uniporal oscules are on the top surface, especially visible in 105677 (B) ZMBN 105678 with Hexactinellida growing on it; (C, D) Thick section (ZMBN 105675) showing the thick cortex, a uniporal oscule with a single sphincter (arrow) and an abundance of oxyasters in the choanosome; (E) Thick section showing the sterrasters and oxyasters in the choanosome; (F) Sterraster; (G) Oxyasters; (H) Spherasters.

moderately thick: $1.1-1.2 \mathrm{~mm}$. Skeleton organization is in accordance with previous descriptions (Cárdenas et al., 2013). Oxyasters are very abundant in the choanosome. Sub-circular crystalline structures were observed in the choanosome, about $45-112 \mu \mathrm{m}$ in diameter with radial clear fibrous organization.

\section{SPICULES, ZMBN 105675 (FIGURE 12F-H)}

Megascleres: (a) oxeas, length: $3375-4154.5-4750 \mu \mathrm{m}$, width: $60-71.5-85 \mu \mathrm{m}$. (b) orthotriaenes, rhabdome length: up to $3750 \mu \mathrm{m}$; width: $70-82.2-90 \mu \mathrm{m}$; orthotriaene clad length: 430-771.4-1032 $\mu \mathrm{m}$. Microscleres: (c) sterrasters, subspherical, smooth rosettes, length: 90-101.9-116 $\mu \mathrm{m}$. (d) spherasters, spiny, $13-17.7-27 \mu \mathrm{m}$ in diameter. (e) oxyasters, smooth, $20-42.6-70 \mu \mathrm{m}$ in diameter.

\section{BATHYMETRIC RANGE}

40-3000 m (Cárdenas et al., 2013).

\section{DISCUSSION}

We identified these specimens as G. phlegraei and not $G$. parva - its sister species from the Arctic (Cárdenas et al., 2013) - based on the external morphology (thick cortex, regular smooth surface) and fairly large sterrasters. But we note however that these sterrasters are spherical as in some
NWA specimens, and not elongated as in NEA specimens (Cárdenas et al., 2013). We re-examined sections of G. phlegraei ZMBN 77929 (Korsfjord, Norway) for crystalline structures, and we found many: small $(27-37 \mu \mathrm{m})$ dirty sub-circular ones were very abundant below the cortex, larger ones (similar to the ones observed in the MAR-Eco specimen) were observed deeper in the choanosome.

Stelletta tuberosa (Topsent, 1892)

(Figures 13A \& 14)

NOTE

We place this Stelletta in the Geodiidae based on molecular phylogeny results from Cárdenas et al. (2011). It seems that, like Stelletta tuberosa, many species of Stelletta are actually Geodia species that have lost their sterrasters, they group in a Geostelletta ${ }^{p}$ clade (named according to the rules of the PhyloCode). Before reallocating these Stelletta species in a new Geodiinae genus, we are waiting for more sequences of Stelletta species to have a better morphological understanding of this Geostelletta ${ }^{p}$ clade. 

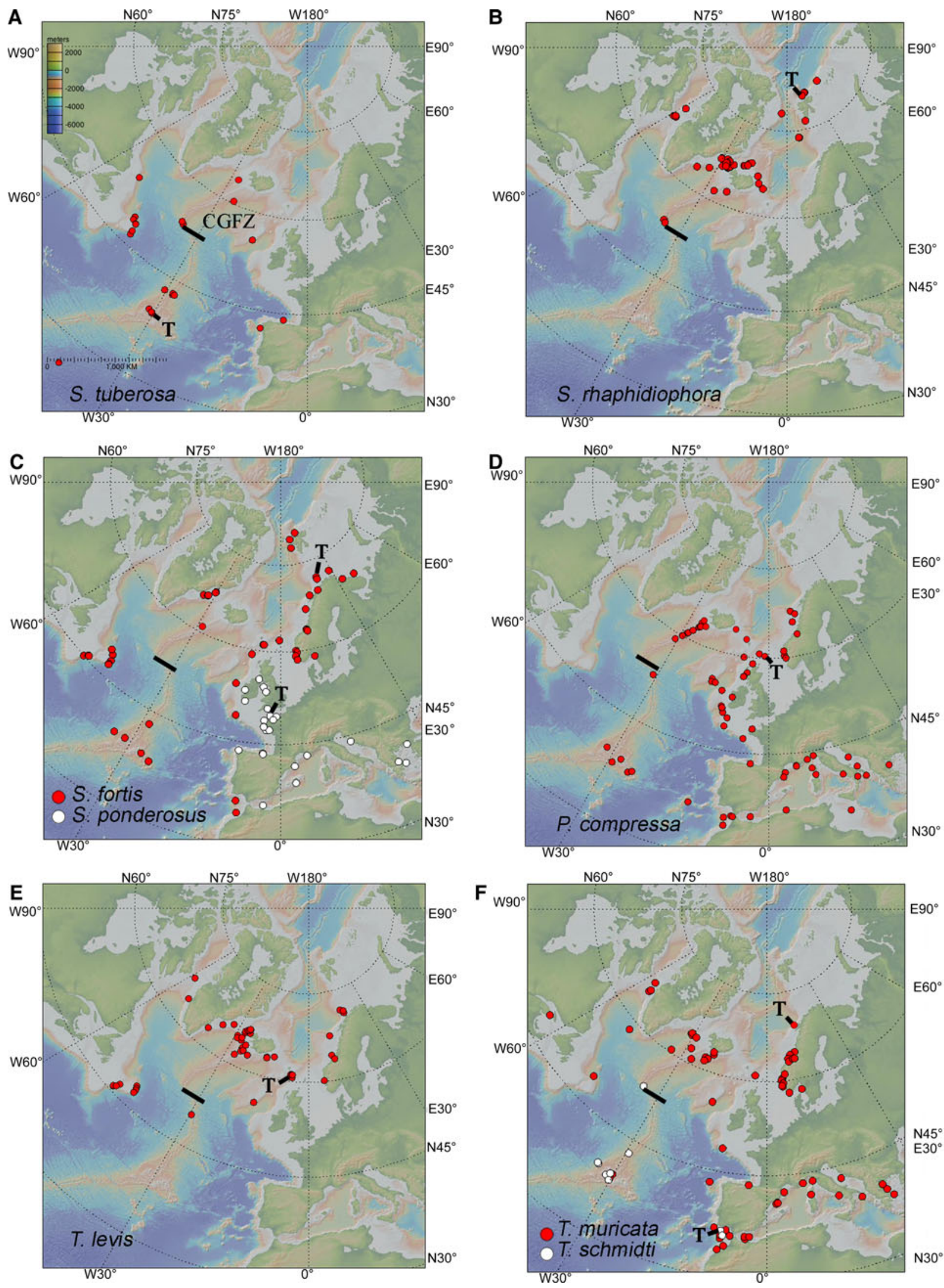

Fig. 13. Distribution maps. T, type locality; CGFZ, Charlie-Gibbs Fracture Zone. Maps generated with GeoMapApp 3.3 (http://geomapapp.org). 

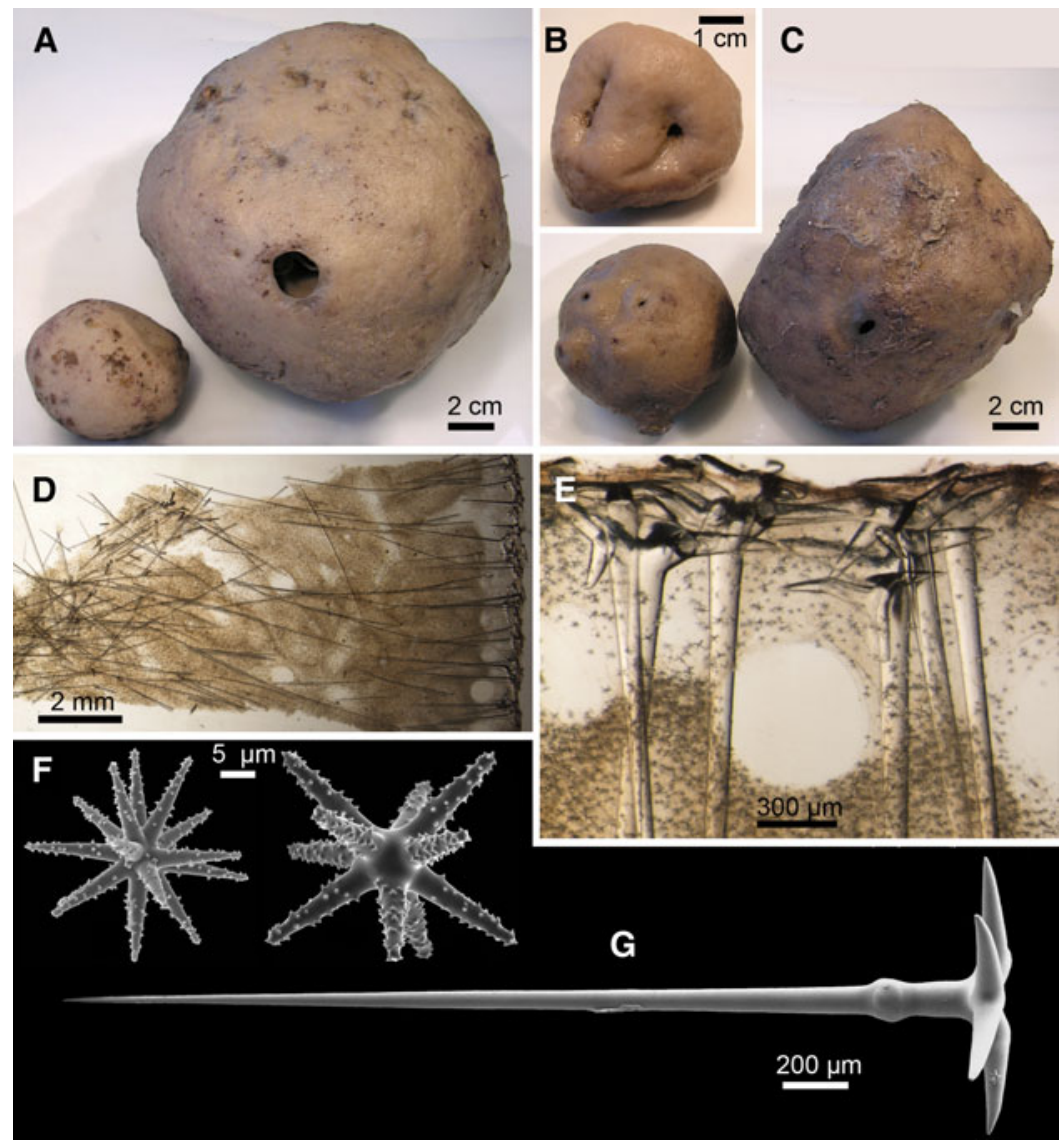

Fig. 14. Stelletta tuberosa (Topsent, 1892): (A) ZMBN 105649 (large) and ZMBN 105650 (small); (B) ZMBN 105679; (C) ZMBN 105610 (small with four oscules) and ZMBN 105611 (large); (D) Thick section (ZMBN 105650); (E) Close-up on thick section showing the cortex with dichotriaenes and large sub-cortical canals. Oxyasters are abundant in the choanosome; (F) Oxyasters; (G) Dichotriaene with typical swelling below the cladome.

\section{MATERIAL}

Two specimens from 40-367, $2961 \mathrm{~m}$ : ZMBN 105610-11. One specimen from 50-373, $2600 \mathrm{~m}$ : ZMBN 105648. Two specimens from 52-374, $2977 \mathrm{~m}$ : ZMBN 105649-50. One specimen $70-385,1650 \mathrm{~m}$ : ZMBN 105670. One specimen from 72-386, $2548 \mathrm{~m}: \mathrm{ZMBN} 105679$.

\section{COMPARATIVE MATERIAL EXAMINED}

MNHN-DT835 (slide), '1888-122', det. by Topsent. MNHNDT1896 (slide), Station 183-1896, det. by Topsent. MNHNDT3012 (slide), off Galicia, Spain, Station 3012, 42.44167, -9.48333 , $1680 \mathrm{~m}$, recorded in Topsent (1928). MNHN-DCL4066, Bay of Biscay, 4400 m, BIOGAS V expedition (Centob), det. by P. Cárdenas. ZMAPOR 21665, South Azores Seamounts, $26^{\circ} 16.098^{\prime} \mathrm{N} \quad 38^{\circ} 09.931^{\prime} \mathrm{W}, \quad 2110 \mathrm{~m}$, EMEPC/G3/o8.10, det. by P. Cárdenas. RMNH Por1454, CANCAP-V Expedition. SNMH \#474, Swedish Arctic Exp. 1871, Station 37, 53.56667, -52.01667, $1792 \mathrm{~m}$, det. by P. Cárdenas. UPSZMC 78301, Flemish Cap, NEREIDA 2009, field\#DRo6-38, 48.291, -44.06, $1348 \mathrm{~m}$, det. by P. Cárdenas. UPSZMC 78302, Flemish Cap, NEREIDA 2009, field\#DRo7-33, 48.256, - 44.03, $1339 \mathrm{~m}$, det. by P. Cárdenas. UPSZMC 78269, Flemish Cap, NEREIDA 0609, Station BC89, 48.974, $-45.272,1574 \mathrm{~m}$, det. by P. Cárdenas; ZMUC, Ingolf Expedition, Station 78, Reykjanes Ridge, 60.61667, -27.86667, 1505 m, Station 90, Denmark Strait, 64.75, - 29.1, 1070 m, det. by P. Cárdenas.

\section{OUTER MORPHOLOGY AND SKELETON}

ORGANIZATION (FIGURE 14A-E)

Massive subspherical usually with a single large oscule but specimen 105610 has four. Large conspicuous sphincters can be found around the oscules. Colour in ethanol is brownish. Thick sections were made for 105649 and 105650. The cladomes of the triaenes and oxyasters (large and small sizes) are embedded in an ectosome about $200-250 \mu \mathrm{m}$ thick. Below the ectosome there is a lighter area $\sim 500 \mu \mathrm{m}$ thick with large subcortical canals and where oxyasters are more scarce. Finally, the choanosome is rich in oxyasters. Large oxeas tend to join the rhabdomes of the triaenes thus making thick radial bundles in the choanosome. Small crystalline structures $(27-37 \mu \mathrm{m}$ long), radial star shaped to elongated shape were commonly found in the sections of 105649, only in the sub-ectosomal area and especially in its canals. Many Globigerina (planktonic Foraminifera) can be found in the choanosome.

SPICULES, ZMBN 105649 (FIGURE 14F, G)

Megascleres: (a) large oxeas, length: 4000-4600-5100 $\mu \mathrm{m}$ $(\mathrm{N}=5$ ), width: 40-53-65 $\mu \mathrm{m}$; (b) dichotriaenes (plagiotriaenes are rare), massive, rhabdome was usually straight but sometimes bent, it often had a distinct swelling below the cladome, rhabdome length: 1525-2552.2-3800 $\mu \mathrm{m}$ $(\mathrm{N}=8)$, width: $70-115.5-145 \mu \mathrm{m}$, protoclad: $80-137.9-$ 


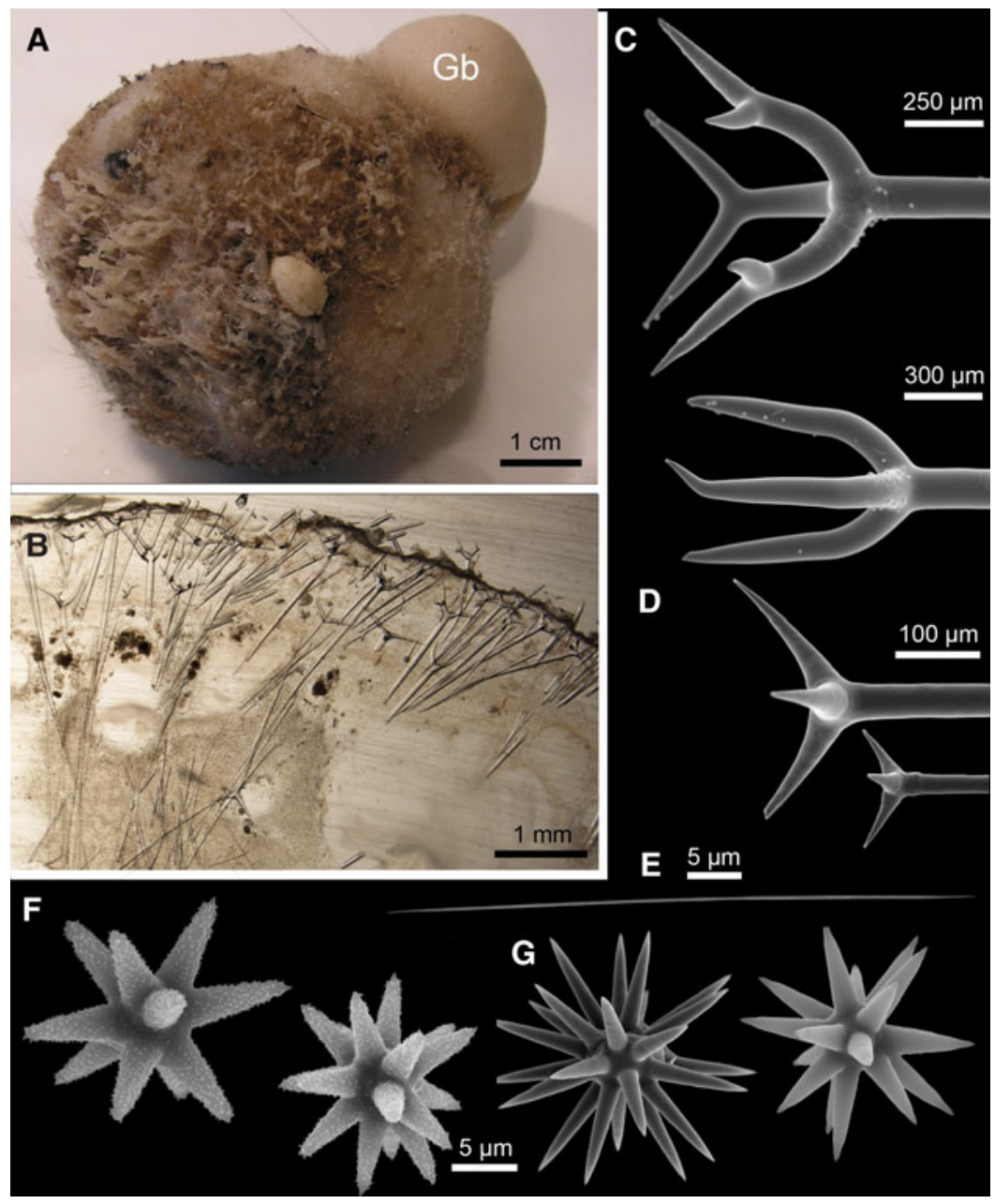

Fig. 15. Stelletta rhaphidiophora Hentschel, 1929: (A) ZMBN 105664 overgrown by Geodia barretti (ZMBN 105665); (B) Thick section (ZMBN 105682); (C) Forward-oriented dichotriaene and plagiotriaene; (D) Small plagiotriaenes; (E) Single raphid from a trichodragma; (F) Strongylasters; (G) Oxyasters.

$250 \mu \mathrm{m}$, deuteroclad: 100-289.5-390 $\mu \mathrm{m}$. Microscleres: (c) oxyasters, spiny, diameter: $16-34.1-57 \mu \mathrm{m}$.

\section{BATHYMETRIC RANGE}

454-4400 m (Topsent, 1892; this study).

\section{DISCUSSION}

This is the Stelletta sp. recorded by Murillo et al. (2012) off Newfoundland (F. J. Murillo, personal communication). We have also identified this species in the NEREIDA 2009 material collected in the same area (DRo6, DRo7, BC89). Larger oxyasters were measured in the other specimens, 105611 had oxyasters sizes up to $66 \mu \mathrm{m}$ while 105679 had oxyasters sizes up to $68 \mu \mathrm{m}$. In the specimens described by Topsent $(1892,1904,1928)$ from the Azores, and some we examined from Newfoundland, the actines of oxyasters usually have a tiny inflated tip. The MAR-Eco specimens, the Ingolf Expedition specimens, some Newfoundland specimens (UPSZMC 78269) and the specimen from Bay of Biscay do not have such a clear inflated tip. The former may be because the actines are thicker; on the other hand, in the Bay of Biscay specimen, it may be because the actines are so thin.

The dichotriaenes of 105670 and 105679, MNHN-DCL4066 and some specimens described by Topsent (1904) from the Azores and Spain do not have a swelling on the rhabdome.
The rhabdomes of Newfoundland specimens are swollen (UPSZMC 78302) (although not as much as in the southern MAR-Eco specimens) or not (\#474, UPSZMC 78301, 78269). So at this point, it is important to emphasize that the inflated tip of actines and the swelling of rhabdomes are not diagnostic characters of this species, they may be absent. Anatriaenes (in 105670) and pro/mesotriaenes (in 105679) were observed. The Bay of Biscay specimen (MNHN-DCL4066) and the one of the South Azores Seamounts (ZMAPOR 21665) had larger oxyasters (up to $96 \mu \mathrm{m}$ ) with thinner and pointier actines.

Family ANCORINIDAE Schmidt, 1870 Genus Stelletta Schmidt, 1862

Stelletta rhaphidiophora Hentschel, 1929

(Figures 13B \& 15)

\section{MATERIAL}

Two specimens from Station 70-385, $1650 \mathrm{~m}$ : ZMBN 105664, 105668. One specimen from Station 72-386, $2548 \mathrm{~m}$ : ZMBN 105682.

COMPARATIVE MATERIAL EXAMINED

Stelletta rhaphidiophora, ZMBN 85222, Iceland, 67.71972, -19.9, BIOICE 3661, $604 \mathrm{~m}$; ZMBN 85223, H2Deep 2008 
expedition, Schultz Massive Seamount, 73.78333, 7.81667, ROV Dive 6, 1600-1760 m; UPSZMC 78297, PA2010-009, set. 155, West Greenland, 66.85177, $-5845597,847 \mathrm{~m}$; UPSZMC 78998, PA2010-009, set. 156, West Greenland, $66.8143,-5806363,853 \mathrm{~m}$. Stelletta normani, ZMBN 77930, Langenuen, Norway, 59.88, 5.51, 45-355 m.

\section{OUTER MORPHOLOGY AND SKELETON}

ARRANGEMENT (FIGURE 15A, B)

Massive subspherical, very hispid. Diameter of the specimens range between $6 \mathrm{~cm}$ (105664), $2 \mathrm{~cm} \mathrm{(105668)} \mathrm{and} 4 \mathrm{~cm}$ (105682). A small Geodia barretti (105665) is growing on 105664 (Figure 15A). Surface colour in ethanol is whitish (sometimes dirty brown due to the sediments trapped in the hispid layer), choanosome colour is light brown. Oscules and pores not visible. Thick sections of 105682 were made. Cortex is $2-2.5 \mathrm{~mm}$ thick. Vitreous cortex, light greyish with two distinct layers of equal thickness: (i) the upper layer is covered with a very thin layer ( $50 \mu \mathrm{m}$ or less) composed of a dense accumulation of strongylasters; below, there are small canals surrounded by trichodragmas and asters, (ii) the lower layer is fibrous with less trichodragmas and some asters. Radial bundles of dichotriaenes spread out like a fan in the cortex, their clads are essentially present in the upper layer of the cortex. Between those bundles, we find large sub-cortical canals. Below these bundles of dichotriaenes, large oxeas are present in no particular orientation. In the choanosome, oxyasters are very numerous, strongylasters and trichodragmas are also common but in smaller numbers.

\section{SPICULES, ZMBN 105682 (FIGURE 15C-G)}

Megascleres: (a) large oxeas, most were broken, up to $6500 \mu \mathrm{m}$ in length, $80 \mu \mathrm{m}$ in width; (b) massive triaenes with more or less forward oriented clads, large triaenes look like protriaenes, clads are usually divided in two but not always, rhabdome was straight or usually bent, rhabdome length: 1750-4010$6000 \mu \mathrm{m} \quad(\mathrm{N}=15)$, width: $45-83.9-125 \mu \mathrm{m}$, protoclad: $60-149.2-250 \mu \mathrm{m}$, deuteroclad: $100-305.2-480 \mu \mathrm{m}$, clad (not divided): $780-1500 \mu \mathrm{m}$. (c) small plagiotriaenes, usually found in the lower portion of bundles, they may be young triaenes or a separate category, rhabdome length: $800-900-1100 \mu \mathrm{m}(\mathrm{N}=4)$, width: $20-26.2-30 \mu \mathrm{m}(\mathrm{N}=$ 4), clad: $140-182.5-270 \mu \mathrm{m} \quad(\mathrm{N}=4)$. Microscleres: (d) smooth oxyasters, with sharp numerous actines, diameter: 12.5-20.1-27.5 $\mu \mathrm{m}$; (e) spiny strongylasters, sometimes with slightly inflated actine tips, diameter: 10-16.1-25 $\mu \mathrm{m}$; (f) trichodragmas, length: $27.5-38.6-55 \mu \mathrm{m}$, width: 6-8.9$12.5 \mu \mathrm{m}$.

\section{BATHYMETRIC RANGE}

241-2548 m (Klitgaard \& Tendal, 2004; this study).

\section{DISCUSSION}

In the original description of S. rhaphidiophora, there are two categories of anatriaenes, characteristic flattened ones and more usual ones (Hentschel, 1929). Although we did not find the flattened anatriaenes in any of our specimens, we are sure of our identification since the rest of the spicule morphologies and measurements perfectly match the original description and our comparative material. We did not find the common anatriaenes in 105682 but we found two in 105664: rhabdome length $>4100 \mu \mathrm{m}$, width: $30 \mu \mathrm{m}$, clad: $130-160 \mu \mathrm{m}$. This is the first time SEM observations are made for this species. It shows that the strongylasters have spined actines (Figure $15 \mathrm{~F}$ ), which are not visible with the optical microscope, and thus not reported in the original description. As observed in the boreo-arctic Geodia species (Cárdenas et al., 2013), there is some variation in the maximum size choanosomal oxyasters can reach. Type material has oxyasters that reach $40 \mu \mathrm{m}$ (Hentschel, 1929), but in the MAR-Eco specimens the oxyasters only reach $27.5 \mu \mathrm{m}$. In ZMBN 85222 from Iceland $(604 \mathrm{~m})$ and UPSZMC 78297-78298 from Davis Strait $(\sim 850 \mathrm{~m})$, oxyasters respectively reach 65 and $56 \mu \mathrm{m}$ and have an inflated centre. On the other hand, specimens from the Greenland Sea, near the Schultz Massive seamount and the Arctic Mid-Atlantic ridge (ZMBN 85223, 1600$1760 \mathrm{~m}$ ) have smaller oxyasters (up to $25 \mu \mathrm{m}$ ) like in the MAR-Eco specimens; but they are in very low numbers, unlike the MAR-Eco specimens. ZMBN 85223 also has very few trichodragmas, rare and small triaenes. It is interesting to note that Geodia hentscheli (ZMBN 77925) collected from the same locality at similar depth has a similar phenotype: low number of oxyasters, rare and smaller triaenes (Cárdenas et al., 2013, Figure 12D, Table 3) so in our opinion environmental parameters around the Schultz Massive seamount clearly influence these spicule morphologies, abundances and sizes.

The MAR-Eco specimens considerably extend the range of this Arctic species southwards. Furthermore, our comparative material from the Davis Strait extends its range to the West. Stelletta rhaphidiophora is an amphi-Atlantic Arctic species while its sister-species, Stelletta normani Sollas, 1880 is typically boreal (P. Cárdenas, unpublished data). In the field, these species can usually be distinguished by looking at their colour and a cross-section in their cortex with the naked eye. Stelletta normani is usually hairy brown while $S$. rhaphidiophora is hairy white. Stelletta normani has a clear double-layered cortex with (i) a bright white layer (packed with trichodragmas) and (ii) a vitreous grey layer (fibrous layer). Stelletta rhaphidiophora has more of a vitreous grey single-layered cortex since the upper white layer is less obvious and bright (because it never has as much trichodragmas).

Genus Stryphnus Sollas, 1886
Stryphnus fortis (Vosmaer, 1885)

(Figures $13 \mathrm{C} \& 16$ )

\section{MATERIAL}

One specimen from Station 50-373, 2600 m: ZMBN 105640.

\section{COMPARATIVE MATERIAL EXAMINED}

Stryphnus fortis, ZMAPOR 02189, holotype, wet specimen, Willem Barents Sea Expedition 1880-1881, Barents Sea, $71.91667,20.51667,327 \mathrm{~m}$ (schizoholotype, RMNH 59, not seen); ZMUC, Ingolf Expedition, Station 78, Reykjanes Ridge, $60.61667,-27.86667,1505 \mathrm{~m}$; ZMBN 82977, Korsfjord, Norway, 60.161667, 5.174722, 200-400 m; ZMBN 85224, Langenuen, Norway, 59.88333, 5.51667; ZMBN 89724 and 89727, Spitsbergen, 80.534167, 15.351667, $215 \mathrm{~m}$; UPSZMC 78303, NEREIDA 2009, field\#DRo3-12, Flemish Cap, 48.38738833, -44.200891, $1324 \mathrm{~m}$; UPSZMC 78304, NEREIDA 2009, field\#DR15-31, Flemish Cap, 47.628715, 
-43.53382667, $1358 \mathrm{~m}$; UPSZMC 153297, Ramsö, Kosterfjorden, Sweden, $\sim 200 \mathrm{~m}$, original det. by H. Alander in 1935 as S. ponderosus var. rudis; field\#BDV1132, Celtic Explorer 13008, off Western Ireland, Porcupine Bank, ROV 15, 54.056, - 12.5548, 1401 m; PC794, field\#BDV1514, Celtic Explorer 13008, off Western Ireland, Globan Spur, ROV 45, 49.0101, $-10.9449,654 \mathrm{~m}$. Stryphnus ponderosus, Mc3395, Rathlin Island, 55.30797, $-6.26878,29 \mathrm{~m}$.

\section{OUTER MORPHOLOGY AND SKELETON}

ORGANIZATION (FIGURE 16A, B)

The single irregular specimen about $7 \mathrm{~cm}$ wide 'glues' together three G. atlantica $(105639,105641,105642)$ and one Stelletta tuberosa (105648) (Figures 3A \& 16A). Colour is dark brown in ethanol. Surface is rough. Radial organization of the skeleton at the surface, more confused in the choanosome. The cladomes of short-shafted dichotriaenes and plagiotriaenes reach a thin fibrous ectosome and sometimes slightly cross it. We could not find sanidasters in the ectosome. Below this ectosome and between the bundles of triaene rhabdomes there are many subectosomal canals. The ectosome and the subectosomal canals make a light layer $1 \mathrm{~mm}$ thick. A few anatriaenes and mesoanatriaenes were also occasionally found in this layer but usually crossed the ectosome (on sections \# 1 and \#2). In the choanosome, there is a dense accumulation of oxyasters and oxeas in a confused arrangement. Large granular cells are present in the ectosome but are not obvious (they are not coloured).

SPICULES, ZMBN 105640 (FIGURE 16C-G)

Megascleres: (a) oxeas, slightly bent, length: 1575-2118$2750 \mu \mathrm{m}$, width: $22-37.5-55 \mu \mathrm{m}$. (b) dichotriaenes, rhabdome is straight and relatively short, clads are sometimes slightly forward oriented, clads can be irregular with trifurcations, rhabdome length: 390-897-1250 $\mu \mathrm{m}$, width: $25-$ 59.1-70 $\mu \mathrm{m}$, protoclad: $90-148.8-270 \mu \mathrm{m}$, deuteroclad: $110-227.8-300 \mu \mathrm{m}$. (c) plagiotriaenes, their rhabdomes are similar to those of the dichotriaenes, clad: $300-425-580 \mu \mathrm{m}$ $(\mathrm{N}=10)$. (d) anatriaenes, rare, with widely open clads, rhabdome width: $30-39.1-45 \mu \mathrm{m}(\mathrm{N}=6)$, clads: $200-246.7-$ $300 \mu \mathrm{m}(\mathrm{N}=8)$. (e) mesoanatriaenes, rare, with widely open clads and an additional clad on top of the cladome, rhabdome width: $15-21.3-27 \mu \mathrm{m}(\mathrm{N}=3)$, clads: $115-183.3-$ $235 \mu \mathrm{m}(\mathrm{N}=3)$, central clad length: $105-160 \mu \mathrm{m}(\mathrm{N}=2)$. Microscleres: (e) spiny oxyasters, with sharp actines, none are reduced to two actines, smaller sizes have more actines and a large centrum, diameter: $17-41-67 \mu \mathrm{m}$; (f) spiny sanidasters to amphisanidasters, length: $10-11.8-15 \mu \mathrm{m}$.
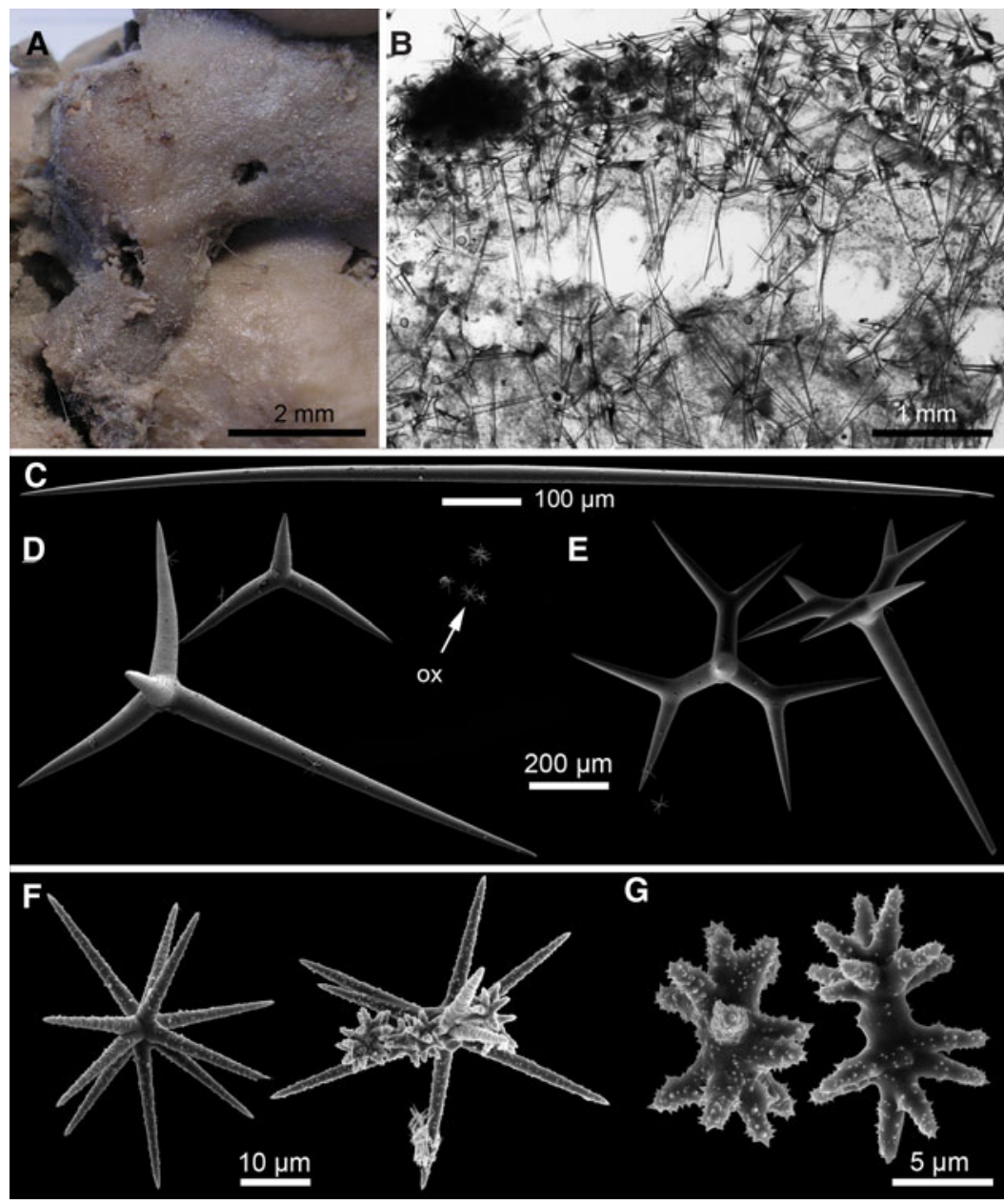

Fig. 16. Stryphnus fortis (Vosmaer, 1885), ZMBN 105640: (A) Specimen overgrowing Geodia atlantica, close up of Figure 3 A; (B) Thick section; (C) Oxea; (D) Plagiotriaenes and oxyasters (ox); (E) Dichotriaene; (F) Oxyasters and amphisanidasters; (G) Amphisanidasters. 


\section{BATHYMETRIC RANGE}

157-2600 m (Klitgaard \& Tendal, 2004; this study).

\section{DISCUSSION}

Historically, the microscleres in Stryphnus fortis were called 'amphiasters' (Sollas, 1888) because they are somewhat symmetrical but we prefer to use 'sanidaster' and 'amphisanidaster' (the latter term was coined by Kelly \& Smith (2012)) to emphasize that they are homologous to the ones found in Asteropus and Ancorina.

The morphology of the MAR-Eco specimen broadly agrees with the description of $S$. fortis but a few differences with the comparative material (including the type) were noted. The sanidasters in the type are slightly longer $(12-12.8-15, \mathrm{~N}=10)$ and the proportion of amphisanidasters ( $v s$ sanidasters) is higher; indeed, the sanidasters in the MAR-Eco specimen often have additional actines on the shaft. We confirm that the type has only plagiotriaenes, as noted by Vosmaer (1885). Although most of the $S$. fortis comparative material we examined (from Norway, Sweden and Flemish Cap) had both plagiotriaenes and dichotriaenes, it was always with a majority of plagiotriaenes. Our specimen has on the contrary a higher proportion of dichotriaenes, which seems to be a characteristic of the southern population of $S$. fortis (Topsent, 1904; Boury-Esnault et al., 1994). Vosmaer (1885) states in his original description that oxyasters come in two sizes. However, this appears to be incorrect as we found only one size when we examined the holotype (ZMAPOR 02189). The oxyasters in the type are fairly large (42-60.9$75 \mu \mathrm{m}, \mathrm{N}=10$ ) compared with the ones observed in the MAR-Eco specimen $(\sim 17-30 \mu \mathrm{m})$, with many actines and a large centrum. More unexpected is the presence of anatriaenes, a spicule never observed before in this species, and usually never found in the genus Stryphnus; anatriaenes have only been found in one atypical New Zealand species rightly called Stryphnus atypicus Kelly \& Smith (2012). Finally, the cortical arrangement in the type and the Norwegian specimen ZMBN 82977 is much more confused than in the MAR-Eco specimen. In the type and ZMBN 82977 some triaenes are somewhat radially disposed but they usually cross the ectosome; many other triaenes can be found in all other directions, including in the choanosome. To conclude, the MAR-Eco specimen is slightly different from typical boreal $S$. fortis but the examination of more southern specimens is required to see if these differences are consistent with a separate population or even species.

According to our observations and comparison with specimen Mc3395 of S. ponderosus, we confirm that $S$. fortis is a valid species, and not a synonym of $S$. ponderosus as suggested by some (Burton, 1926; Koltun, 1966). Stryphnus ponderosus has smaller oxyasters (usually never larger than $25 \mu \mathrm{m}$ in diameter), it is a shallower species $(0-200 \mathrm{~m})$ that lives in temperate waters of the North-East Atlantic (British Isles, Ireland, France, Spain) and Mediterranean Sea, it is often covered by the sponge Desmacella annexa Schmidt, 1870 (Topsent, 1928, Lévi, 1950), which is the case of Mc3395. On the other hand, $S$. fortis is a deep-sea amphi-Atlantic species $(200-2598 \mathrm{~m})$ found from the boreo-arctic region to the Azores, it is often covered by the deep-sea yellow sponge Hexadella detritifera Topsent, 1913. Since S. ponderosus and $S$. fortis mainly differ by the size of the oxyasters and megascleres, we wonder whether they could be conspecific, their spicule differences being a direct consequence of depth and silica concentration in the environment, as shown in other Astrophorina (Cárdenas \& Rapp, 2013). However, molecular data shows that the two species are genetically different (Cárdenas et al., 2011), there is a $2 \mathrm{bp}$. difference in the Folmer COI fragment, and $1 \mathrm{bp}$. in the $28 \mathrm{~S}\left(\mathrm{C}_{1}-\mathrm{D}_{2}\right)$ fragment. So, in our opinion, $S$. fortis and S. ponderosus are sisterspecies that diverged recently from a common ancestor that colonized shallow waters from the deep-sea (or the reverse). This new environment may have influenced the size of the oxyasters. Today the shallow and deep-sea populations may not be genetically connected anymore (this should be tested with a wider sampling) and have retained their respective morphologies.

After examining material collected during the deep-sea NEREIDA 2009 campaign off Newfoundland, we concluded that the $S$. ponderosus recorded off Newfoundland is in fact $S$. fortis (Murillo et al., 2012; Kenchington et al., 2013; Kutti et al., 2013). For example, UPSZMC 78303 from the Flemish Cap has oxyasters which are $30-44.5-75 \mu \mathrm{m}(\mathrm{N}=10)$ in diameter. Likewise, $S$. ponderosus recorded from the Atlantic boreo-arctic region, as a major component of boreal sponge grounds, is in fact S. fortis (Hougaard et al., 1991; Klitgaard, 1995; Klitgaard \& Tendal, 2004).

Vosmaer (1885) gave no measurements for the spicules of S. fortis, so it was originally difficult to identify. Stryphnus rudis Sollas, 1888 was described as a new species based on the fact that it had dichotriaenes and plagiotriaenes ( $v s$ only plagiotriaenes in the type of $S$. fortis). It was collected in the Korsfjord in Norway, where we have collected extensively. The Stryphnus specimens that we found there were similar to the paratype of $S$. fortis so we confirm, as suggested by Topsent (1904), that $S$. rudis is a junior synonym of $S$. fortis. Likewise, it was initially thought that $S$. ponderosus only had dichotriaenes so when specimens were collected with dichotriaenes and plagiotriaenes, they were referred to as S. ponderosus var. rudis Sollas, 1888 (Topsent, 1894, Lévi, 1950; Uriz, 1981). We now know that the proportion of dicho/plagiotriaenes can vary in $S$. ponderosus, so $S$. ponderosus var. rudis becomes a synonym of $S$. ponderosus (except for the records of Alander (1942) in Sweden which belong to $S$. fortis).

\section{Family VULCANELLIDAE Cárdenas et al., 2011 \\ Genus Poecillastra Sollas, 1888 \\ Poecillastra compressa (Bowerbank, 1866)}

(Figures 13D \& 17)

\section{MATERIAL}

One specimen from Station 65-382, 753 m: ZMBN 105660.

\section{OUTER MORPHOLOGY AND SKELETON}

\section{ORGANIZATION (FIGURE 17A)}

Irregular lamellar shape, $5 \mathrm{~cm}$ long, about $1 \mathrm{~cm}$ thick. White specimen in ethanol. Skeleton organization is in complete accordance with the description of Norwegian specimens in Cárdenas \& Rapp (2012).

\section{SPICULES, ZMBN 105660 (FIGURE 17B-F)}

Megascleres: (a) oxeas I, stout, smooth, usually slightly curved, but rarely double-curved, a few modified to styles, or even to strongyles, length: 390-1234.7-2600 $\mu \mathrm{m}$; width: 3- 


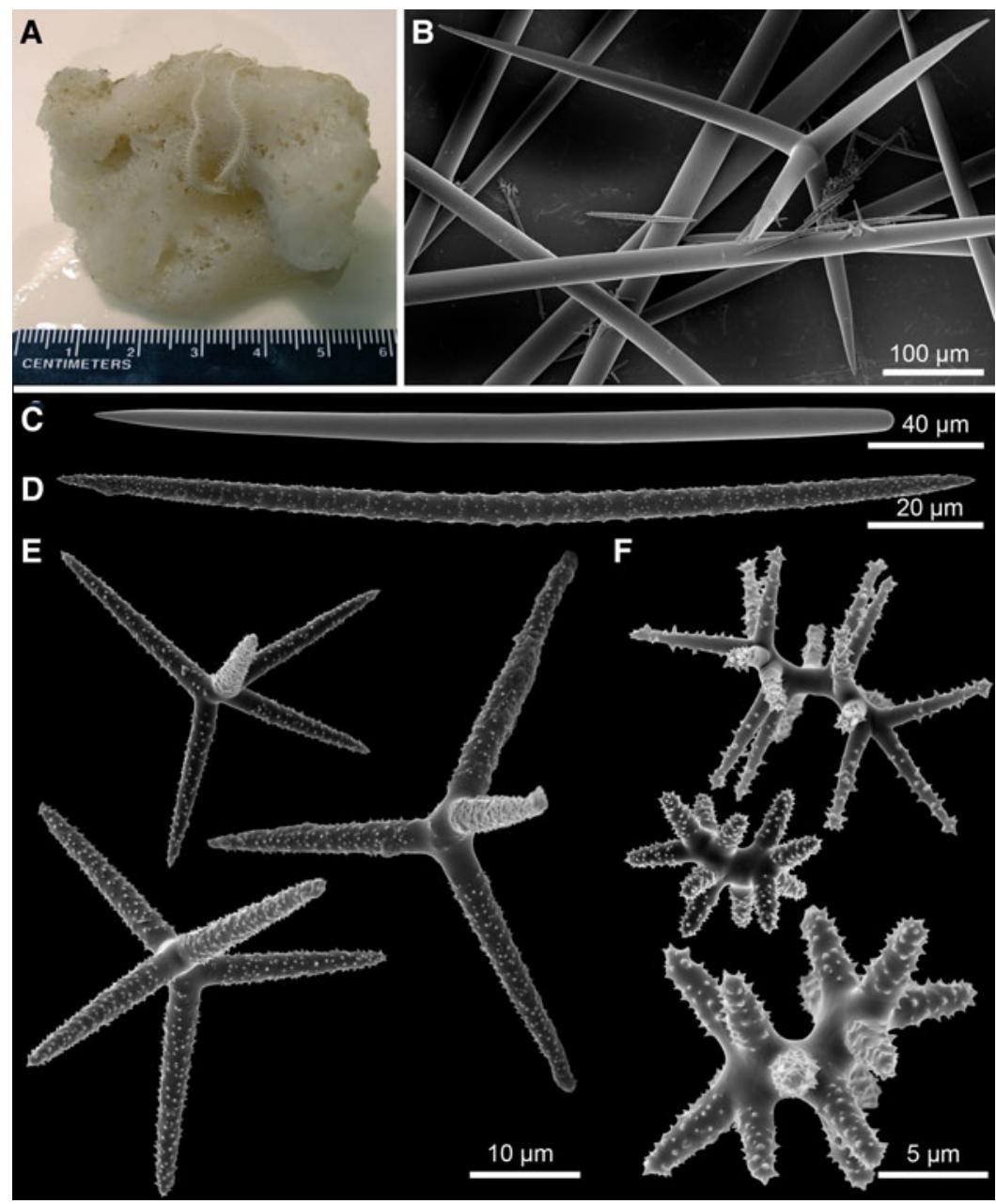

Fig. 17. Poecillastra compressa (Bowerbank, 1866), ZMBN 105660: (A) Specimen; (B) Short-shafted orthotriaenes and oxeas; (C) Style; (D) Microxea; (E) Plesiaster; (F) Spiraster (top) to metaster (bottom).

18.1-27 $\mu \mathrm{m}$. (b) oxeas II, thin and pointy, length: 19502033-2150 $\mu \mathrm{m}(\mathrm{N}=3)$; width: $6.5-7-7 \mu \mathrm{m}(\mathrm{N}=4)$. (c) short-shafted orthotriaenes, sometimes pseudocalthrops (rhabdome $=$ clads), often irregular clads, rhabdome $/$ clad length: 91-199.7-357 $\mu \mathrm{m}$; rhabdome/clad width: $18 \mu \mathrm{m}$ $(\mathrm{N}=1)$. Microscleres: $(\mathrm{d})$ microxeas, in high numbers, microspiny, straight or bent, centrotylote or not, length: 95-165.8$201 \mu \mathrm{m}$; width: $5-5.7-7.5 \mu \mathrm{m}$. (e) spiraster to metaster (frequent), microspiny and fairly fat actines, length: 13-18.2$25 \mu \mathrm{m}$; width: $10-14.8-21 \mu \mathrm{m}$. (f) plesiaster, 3-6 actines, spiny actines, diameter: $24-37.3-57.5 \mu \mathrm{m}$.

\section{BATHYMETRIC RANGE}

o-1740 m (Topsent, 1928, Sarà, 1964).

\section{DISCUSSION}

The presence of strongyles in our specimen is intriguing; they have never been recorded before in this species (Cárdenas \& Rapp, 2012), the rest of the spicules agree well with those of $P$. compressa. More specimens and molecular data are needed to eventually test the status of these Mid-Atlantic ridge populations. Despite numerous records, this species has never been recorded to this day beyond the MAR, in the NWA.
Family THENEIDAE Carter, 1883
Genus Thenea Gray, 1867

Thenea levis von Lendenfeld, 1907

(Figures $13 \mathrm{E} \& 18$ )

MATERIAL

Six specimens from Station 53-375, Faraday seamount, $990 \mathrm{~m}:$ ZMBN 105653-57, 105659.

\section{COMPARATIVE MATERIAL EXAMINED}

Thenea levis, UPSZMC 155199, Flemish Cap, NEREIDA 2009, field\#DRo6-046B， 48.291, - 44.06, 1348 m, det. by P. Cárdenas. UPSZMC 155198, Flemish Cap, NEREIDA 2009, field\#DR12-062, 47.77, - 43.57, $1462 \mathrm{~m}$, det. by P. Cárdenas. UPSZMC 155197, Flemish Cap, NEREIDA 2009, field\#DR18-039, 47.26, $-43.53,1079 \mathrm{~m}$, det. by P. Cárdenas. UPSZMC 78289, PA2010-009, set. 155, West Greenland, $66.85,-58.45,847 \mathrm{~m}$. Additional specimens from the Norwegian coast (Cárdenas \& Rapp, 2012).

OUTER MORPHOLOGY (FIGURE 18A)

$105653-105654$ are the only large specimens with the typical elongated shape, they are respectively 5 and $3 \mathrm{~cm}$ long. The 


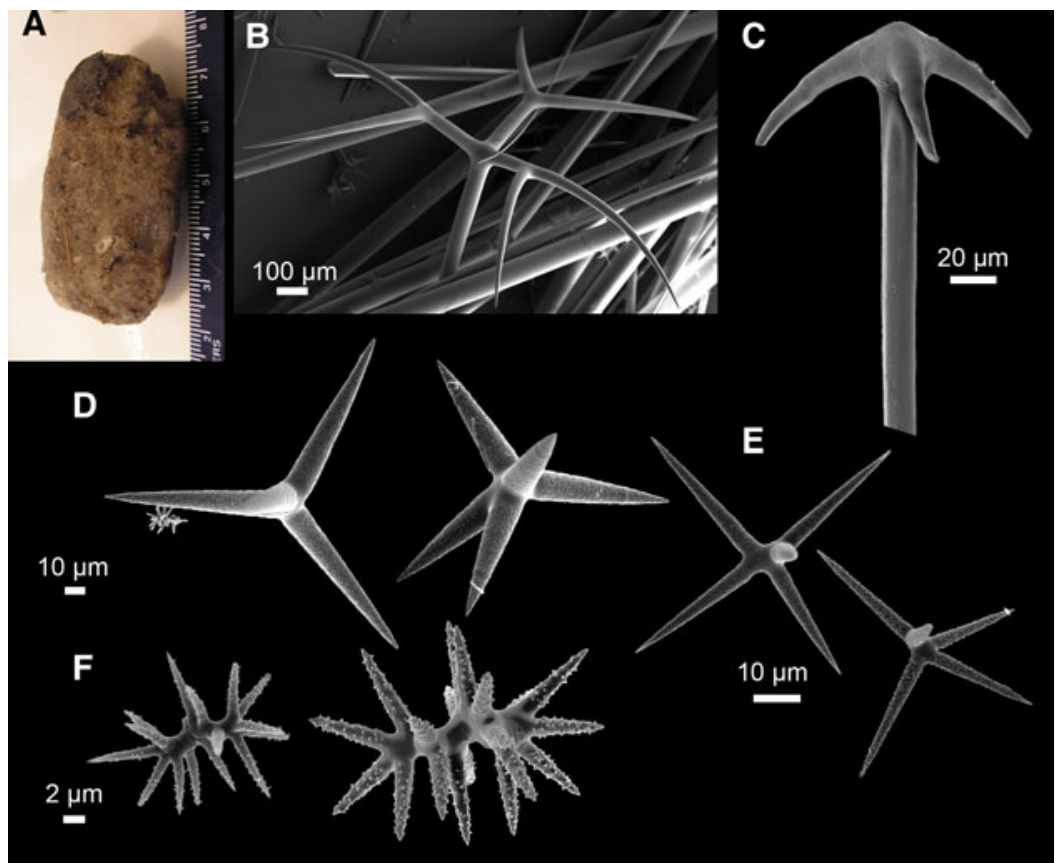

Fig. 18. Thenea levis von Lendenfeld, 1907, ZMBN 105653: (A) Specimen; (B) Dichotriaene; (C) Anatriaene; (D) Large plesiasters; (E) Smaller plesiasters; (F) Spirasters.

other specimens are small, subspherical and possible fragments.

\section{SPICULES, ZMBN 105653 (FIGURE 18B-F)}

Megascleres: (a) oxeas. (b) dichotriaenes, deuteroclads are sometimes bent towards each other. (c) common anatriaenes. Microscleres: (d) plesiasters, 2-6 minutely spined actines, common, length of actine: $24-63.2-116 \mu \mathrm{m}$; actine thickness: $8-20 \mu \mathrm{m}$. (e) spined spirasters to metasters, common, length: $16-20.5-24 \mu \mathrm{m}$.

\section{BATHYMETRIC RANGE}

190-1480 m (Steenstrup \& Tendal, 1982; Cárdenas \& Rapp, 2012).

\section{DISCUSSION}

No protriaenes were observed. In 105654 plesiasters are sometimes reduced to two actines, a feature not observed in Norwegian specimens but fairly common in our NWA specimens (UPSZMC 78289, 155197, 155199). Plesiasters of the MAR-Eco specimens are smaller than the ones measured in a shallower Norwegian specimen (actine length: 30-83.2$145 \mu \mathrm{m}, \mathrm{ZMBN}$ 85230, off Korsfjord, $300 \mathrm{~m}$ ). We are currently missing spicule characters to properly discriminate $T$. levis from the other common North Atlantic Thenea. The SEM observations of the MAR-Eco specimens confirmed that large plesiasters were more minutely spined in $T$. levis (Cárdenas \& Rapp, 2012) but this character is impossible to see without a SEM. We made two new observations: (1) the plesiaster actines in T. levis are 'fat' or bullet-shaped (in the MAR-Eco and comparative material), which is not the case of the plesiasters in T. muricata/schmidti/valdiviae; (2) anatriaenes in $T$. levis are on average more 'open' and with shorter clads than in T. muricata/schmidti/valdiviae. If confirmed these two spicule characters may be used to discriminate T. levis from the other North Atlantic Thenea. We extend the western distribution of $T$. levis by reporting its first presence off Newfoundland (Flemish Cap) at depths of $1079 \mathrm{~m}$ to $1462 \mathrm{~m}$.

\section{Thenea cf. schmidti Sollas, 1886}

(Figures 13F \& 19)

\section{MATERIAL}

Two specimens from 42-368, $2078 \mathrm{~m}$ : ZMBN 105618-19. Six specimens from Station 44-369, $1742 \mathrm{~m}$ : ZMBN 105620-25. One specimen from Station 70-385, $1650 \mathrm{~m}$ : ZMBN 105671.

\section{OUTER MORPHOLOGY AND SKELETON \\ ORGANIZATION (FIGURE 19A-C)}

Subspherical, fairly hispid sponges, $1.5-3 \mathrm{~cm}$ in diameter. Cribriporal oscules in the equatorial area and single naked oscule on the top surface. Thick sections of 105621 and 105671 were made: the skeleton organization is highly similar in both specimens. Large plesiasters are very abundant and uniformly distributed.

SPICULES, ZMBN 105621 AND 105671 (FIGURE 19D-K) Megascleres: (a) oxeas. (b) dichotriaenes with pointy bent rhabdome. (c) few anatriaenes. (d) many protriaenes found in 105624. Microscleres: (e) plesiasters, minutely to fairly spined, very common, 2-7 actines (105621), 4-7 actines (105671), length of actine: $28-89-188 \mu \mathrm{m}$ (105621), 28$89.8-170 \mu \mathrm{m}(105671)$ and up to $204 \mu \mathrm{m}$ (105622); actine thickness: $4-16 \mu \mathrm{m}$. (f) metasters to spirasters, spined, common, length: 24-29.9-36 $\mu \mathrm{m}$ (105621), 24-32.2$41 \mu \mathrm{m}$ (105671).

\section{BATHYMETRIC RANGE}

349-4020 m (Topsent, 1904). 

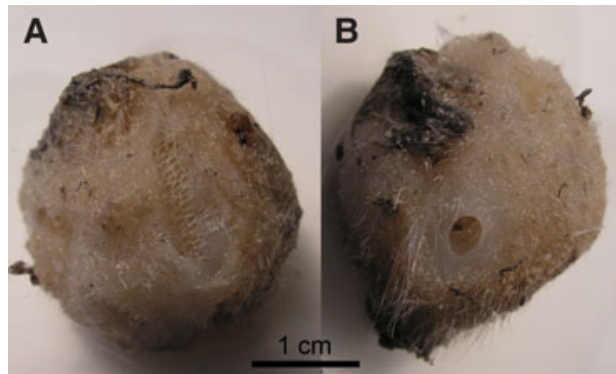

C
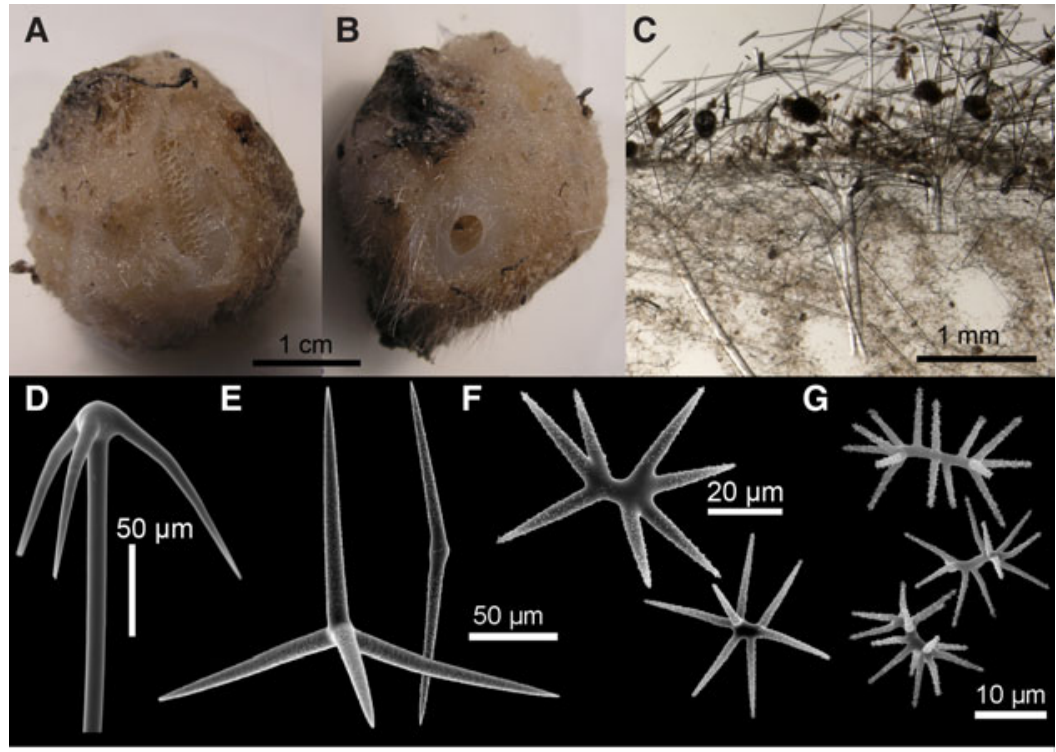

$1+c^{2}$

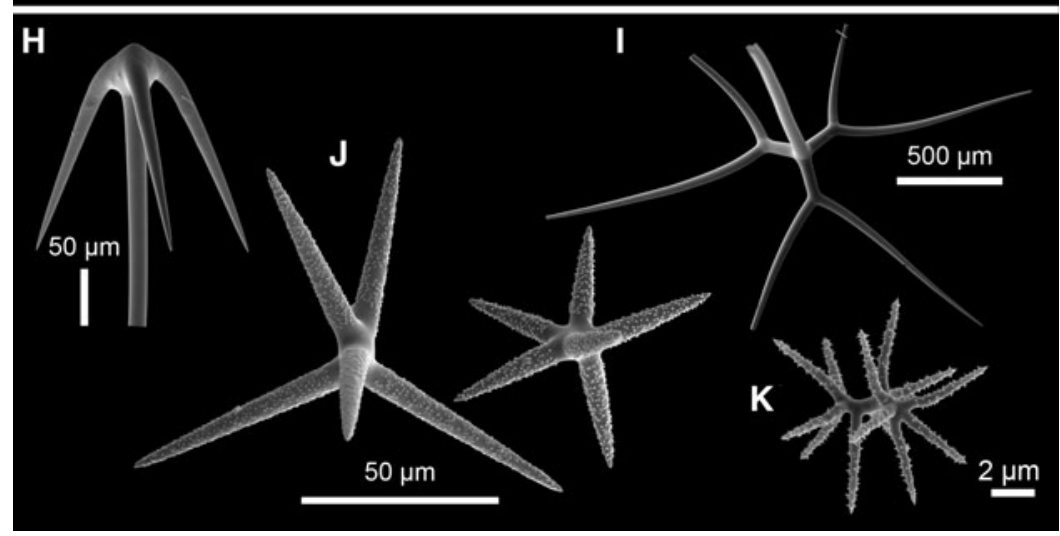

Fig. 19. Thenea cf. schmidti Sollas, 1886, (A-G) ZMBN 105621; (H-K) ZMBN 105671: (A) Side view showing the cribriporal pores in the equatorial area; (B) Top view showing the single naked oscule on the top surface; (C) Thick sections, large plesiasters are very abundant and uniformly distributed; (D) Anatriaene; (E) Plesiasters, one reduced to two actines; (F) Metasters; (G) Spirasters; (H) Anatriaene; (I) Dichotriaene; (J) Plesiasters; (K) Spiraster.

\section{DISCUSSION}

$42-368 / 44-369$ specimens and $70-385$ (105671) come from distant stations and the morphology of the spicules are slightly different and we decided to present both in Figure $19 \mathrm{D}-\mathrm{K}$. Plesiasters reduced to two actines were not recorded in this species before (Sollas, 1888; Cárdenas \& Rapp, 2012) but they are common in the $42-368 / 44-369$ specimens, except for 105671 . This is a tentative identification since without genetic data, it is still difficult to decide whether to call this species T. muricata or T. schmidti (its southern sister-species). Cárdenas \& Rapp (2012) have shown that there are genetic differences between the two species (using the $\mathrm{C}_{1}-\mathrm{D}_{2}$ fragment of 28S), a result which still needs to be confirmed with additional specimens and independent molecular markers. They have also shown that clear morphological characters are still missing to distinguish both species. We decided to call our specimens $T$. cf. schmidti because the morphology of the MAR-Eco specimens agrees more with the original description of this species (Sollas, 1888). All specimens had abundant large plesiasters. Plesiasters have a much wider range than in $T$. valdiviae. It is difficult to separate the largest metasters/spiraters and the smallest plesiasters, there is a continuum (whereas in T. levis, the spiraster category is quite distinct).
Thenea cf. valdiviae von Lendenfeld, 1907

(Figures 20A \& 21)

\section{MATERIAL}

Seven specimens from Station 40-367, $2961 \mathrm{~m}$ : ZMBN 105613-14. 7 specimens from Station 46-372, $3046 \mathrm{~m}$ : ZMBN 105627-31. 1 specimen from Station 52-374, 2977 m: ZMBN 105652.

\section{COMPARATIVE MATERIAL EXAMINED}

Thenea valdiviae, $\mathrm{PC}_{764}$, field\#DR 32-14, Flemish Cap, 48.427, -46.291, NEREIDA 2009, $1264 \mathrm{~m}$. More comparative material from the NEA (Cárdenas \& Rapp, 2012).

\section{OUTER MORPHOLOGY AND SKELETON}

ORGANIZATION (FIGURE 2OA-D)

Sub-globular, slightly flattened, sometimes with a triangular shape. Fairly hispid surface. One to several oscules with large meshed sieves (Figure $20 \mathrm{~B}$ ). Equatorial poral area (also sieved). Specimens all have a dirty colour in ethanol. Thick sections of 105631 were made. Large dichotriaenes are found at the surface, with their cladomes supporting the ectosome in a very regular fashion (Figure 2oD). Bundles of oxeas 
A
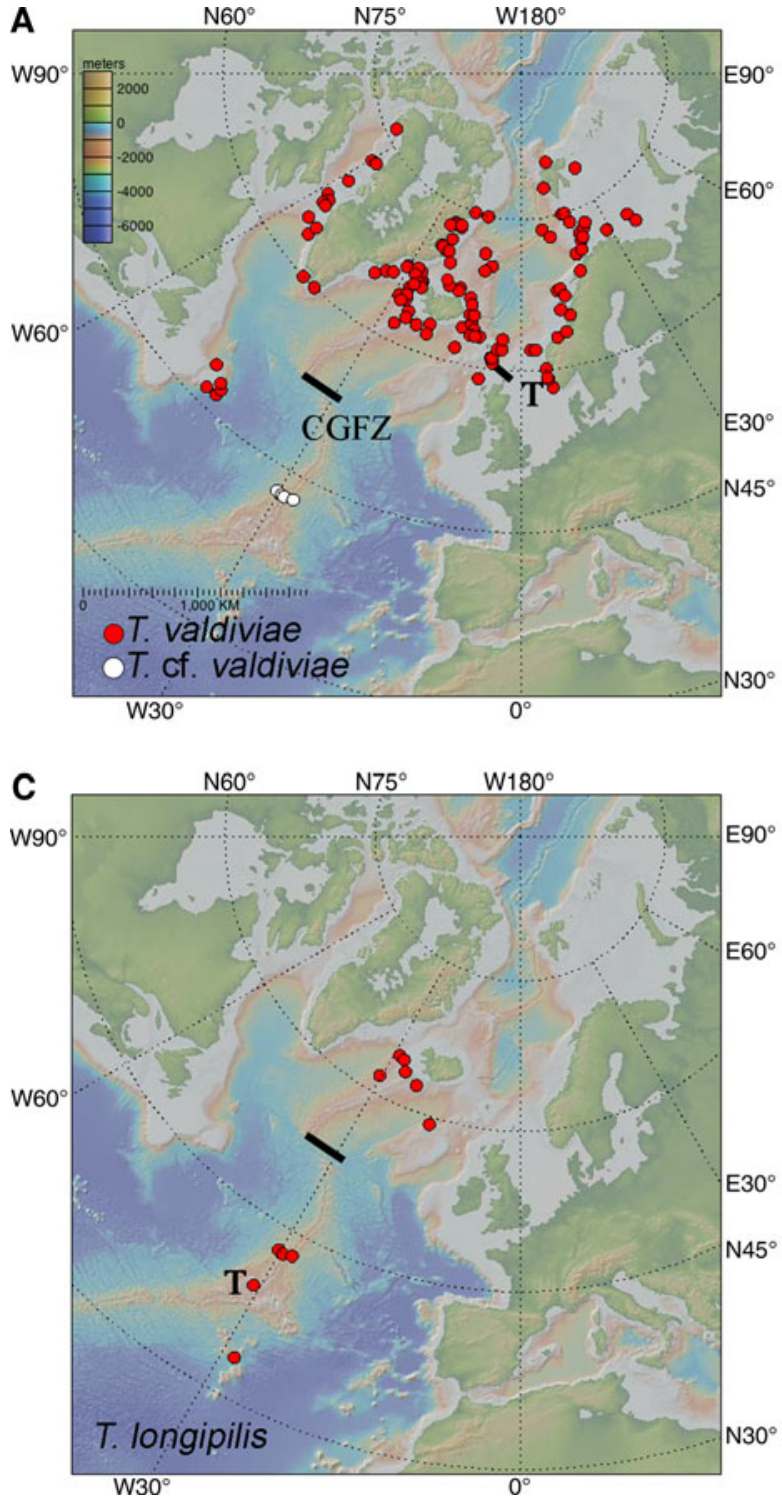
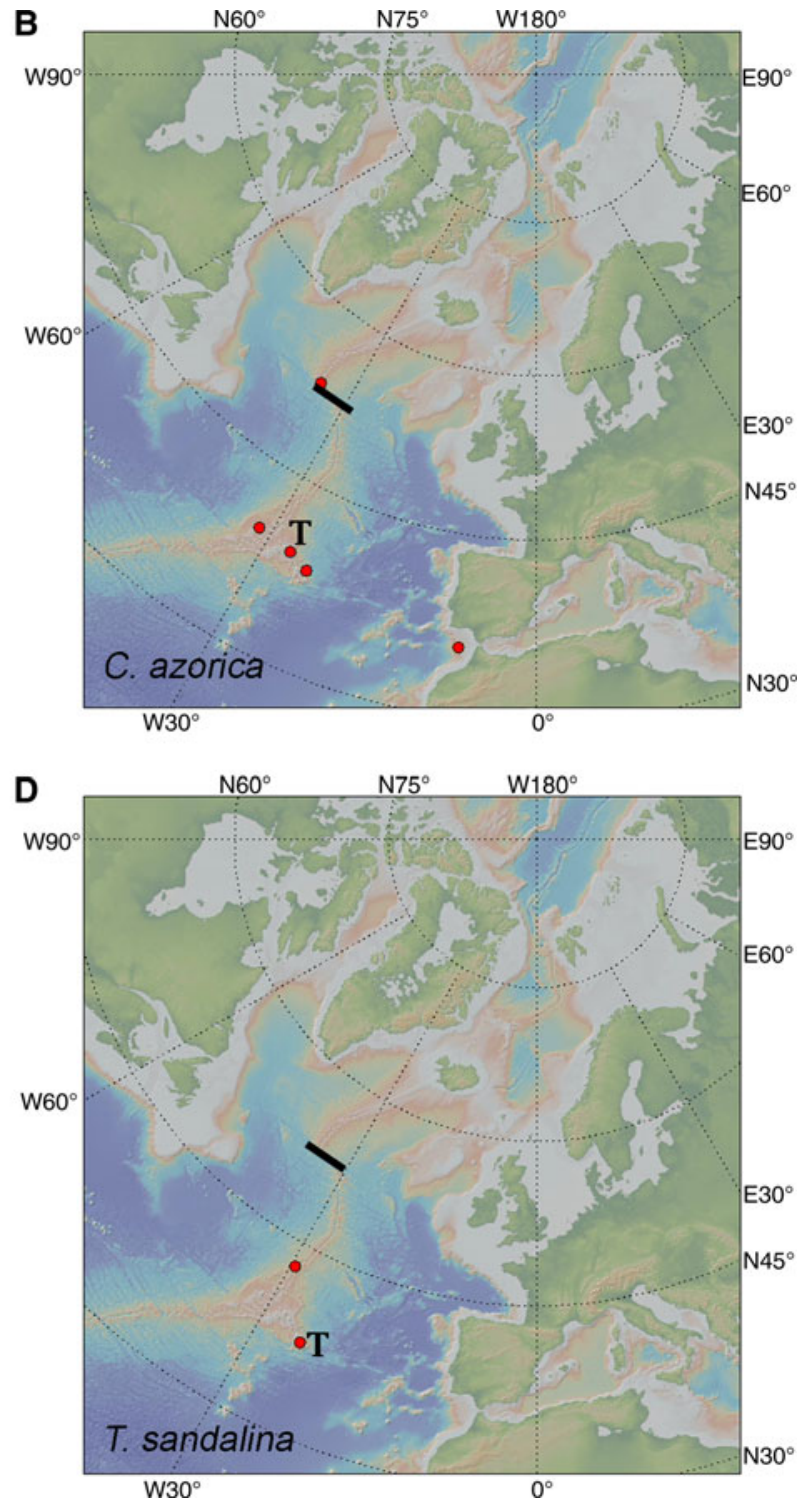

Fig. 2o. Distribution maps. T, type locality; CGFZ, Charlie-Gibbs Fracture Zone. Maps generated with GeoMapApp 3.3 (http://geomapapp.org).

surround the triaenes and cross the ectosome. Spirasters and plesiasters are very abundant throughout the choanosome. Foraminifera (Globigerina especially) are abundant in the choanosome. Sediments are also abundant.

\section{SPICULES, ZMBN 105631, UNLESS OTHERWISE \\ STATED (FIGURE 2OE-G)}

Megascleres: (a) oxeas. (b) dichotriaenes with pointy bent rhabdome. (c) protriaenes, rare (only found in 105614 105627 and 105628). Microscleres: (d) plesiasters, common, usually with 5-7 actines, minutely spined, length of actine: $44-55.3-64 \mu \mathrm{m}$ or $52-63.3-77$ (in 105613); actine thickness: $3-5 \mu \mathrm{m}$. (e) amphiasters (rare spirasters observed, no metasters observed), common, spiny, length: $20-26.6-32 \mu \mathrm{m}$ but they can be up to $47 \mu \mathrm{m}$ long (105613).

\section{BATHYMETRIC RANGE}

100-3046 m (Cárdenas \& Rapp, 2012; this study).

\section{DISCUSSION}

Steenstrup \& Tendal (1982) consider the species to be dimorphic with a spherical arctic form and a more flattened hemispherical boreal form. Cárdenas \& Rapp (2012) later showed that there are two COI (Folmer fragment) haplotypes for this species: the Arctic COI haplotype is identical to the COI of T. muricata while the boreal haplotype has $1 \mathrm{bp}$. difference with the COI of T. muricata. With respect to their external morphologies, the MAR-Eco specimens are similar to the boreal form of T. valdiviae, also collected in western Norway (Cárdenas \& Rapp, 2012, Figure 24C). Spicule measurements are also in the range of more northern specimens (Cárdenas \& Rapp, 2012). Protriaenes were rarely observed and anatriaenes were not found; however, both of these megascleres do seem to be rare in this species (Cárdenas \& Rapp, 2012). We further noted significant spicule differences with boreo-arctic comparative material. Plesiasters are much more common than in boreo-arctic specimens (from the Barents Sea, the Greenland Sea and the NWA) (Cárdenas \& Rapp, 2012). These plesiasters have on average more actines (which are 


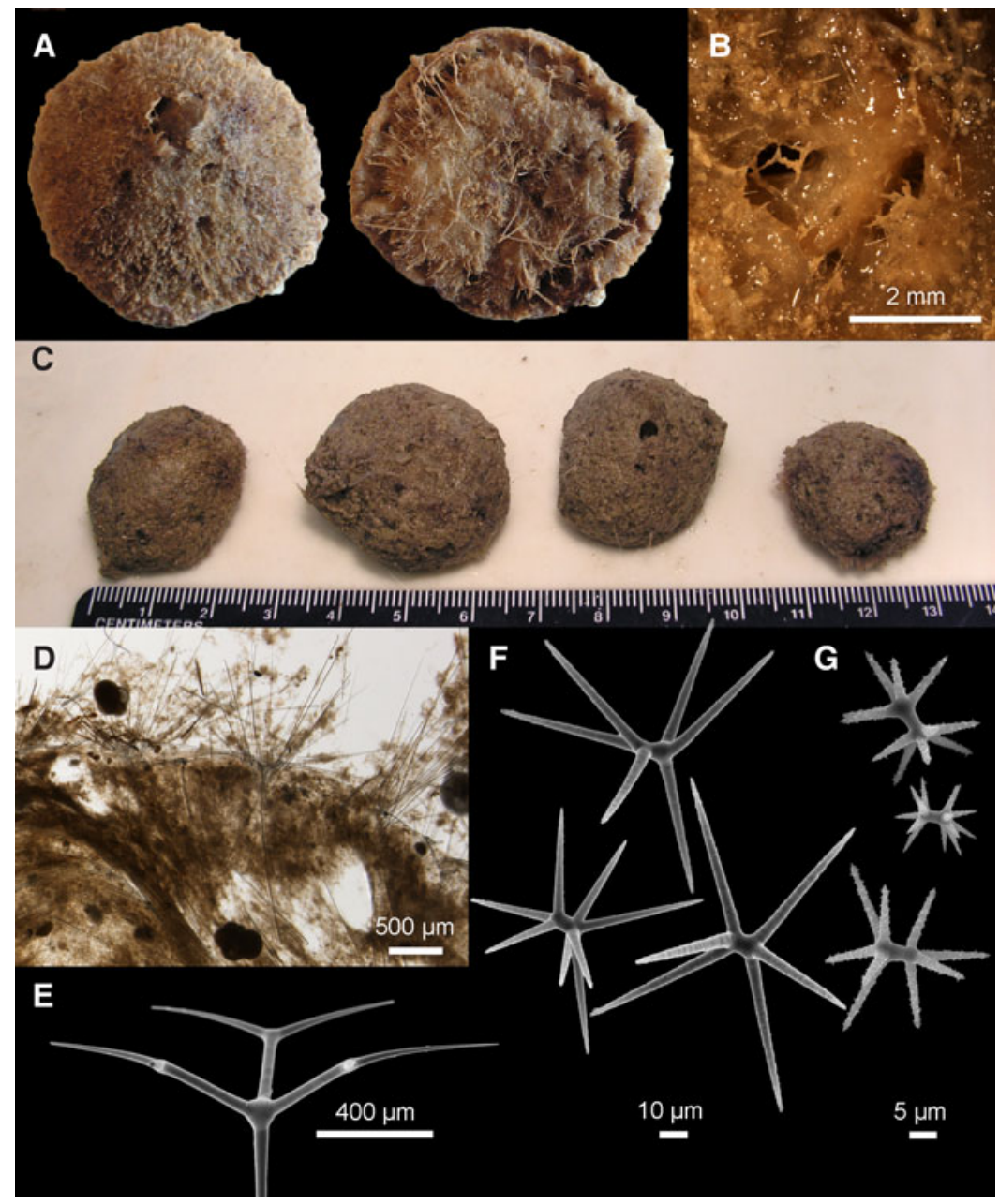

Fig. 21. Thenea cf. valdiviae Lendenfeld, 1907: (A) ZMBN 105627, above and under view (notice the circular poral area), specimen is about $4 \mathrm{~cm}$ in diameter; (B) Large sized mesh over oscules on top surface of ZMBN 105613. (C) ZMBN 105613; (D) Thick section of ZMBN 105631; (E) Dichotriaene (ZMBN 105631); (F) Plesiaster (ZMBN 105631); (G) Amphiasters (ZMBN 105631).

thinner) than boreo-arctic specimens. Above all, the most noticeable difference is the presence of amphiasters (instead of spirasters), which have never been observed in this species before (including in the type from the Faroe Islands). Metasters were absent in the MAR-Eco specimens, although they are present, albeit in small numbers, in boreo-arctic specimens. For these reasons (plesiaster abundance and morphology, amphiasters, metaster absence), we decided to cautiously identify these specimens under the name $T$. cf. valdiviae.

The MAR-Eco specimens would be the deepest T. valdiviae ever collected $(3046 \mathrm{~m})$. These would also be the southernmost record for this species, usually considered to be boreo-arctic. While reviewing the distribution of this species we examined pictures of specimens from Stations 960 (394 $\mathrm{m}$ ) and 1052 (440 m) collected in the Norwegian Sea and Barents Sea and identified by Topsent (1913) as T. muricata (pictures courtesy of M. Bruni, MOM). All these specimens are clearly T. valdiviae with sieved oscules. Specimens from Station 922 could not be retrieved (M. Bruni, personal communication) but since Topsent treated them also as T. muricata we assume they were also T. valdiviae. We also report here the first records of this species off Newfoundland (in the Flemish Cap). Actually, the specimen from the Flemish Cap identified as T. muricata by Murillo et al. (2012, Figure 6J) is also T. valdiviae: the oscule clearly has a sieve.

Suborder SPIROPHORINA Bergquist \& Hogg, 1969 Family TETILLIDAE Sollas, 1886

Genus Craniella Schmidt, 1870

Craniella azorica (Topsent, 1913)

(Figures 20B \& 22)

MATERIAL

Two specimens from Station $70-385,1650 \mathrm{~m}$ : ZMBN 105673-74.

\section{COMPARATIVE MATERIAL EXAMINED}

Craniella azorica, MOM-INV-22534 (04 0889), lectotype here designated, large specimen represented by Topsent (1913, pl. III), paralectotype (smaller specimen), both wet specimens, Azores, near Terceira Island, Station 866, 38.88056, -27.21806, $599 \mathrm{~m}$; MNHN-DT2877, two type slides (one from each type). 

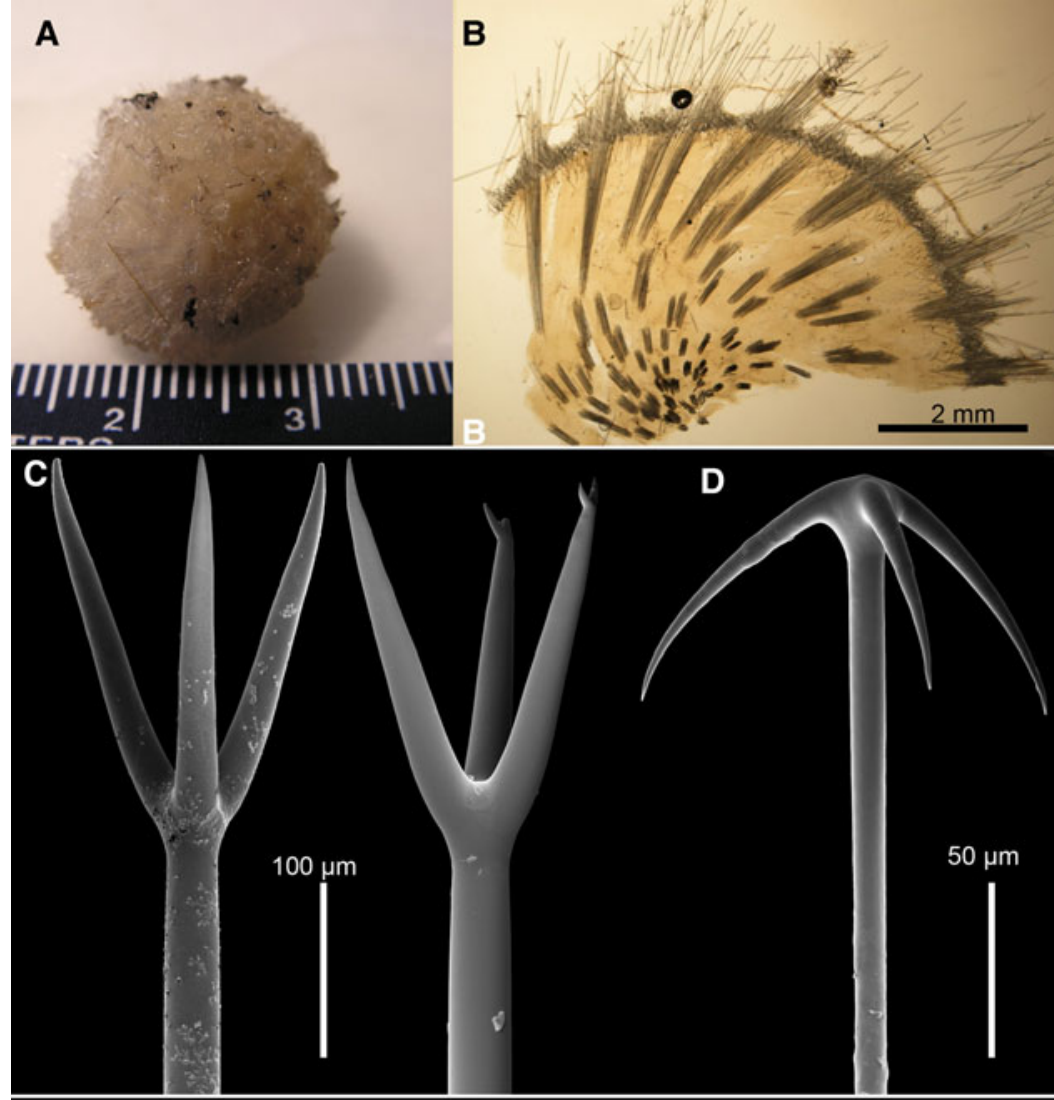

A D

\section{D}

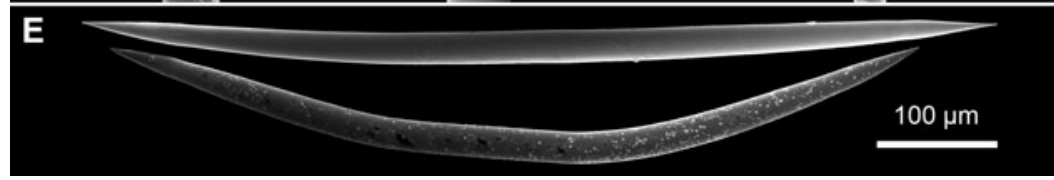

Fig. 22. Craniella azorica (Topsent, 1913), ZMBN 105674: (A) Specimen; (B) Thick section; (C) Protriaenes with equal clads; (D) Anatriaene; (E) Oxeas II.

\section{OUTER MORPHOLOGY AND SKELETON}

\section{ARRANGEMENT (FIGURE 22A, B)}

Both specimens are small spherical hispid sponges, $1 \mathrm{~cm}$ and $1.5 \mathrm{~cm}$ in diameter. Surface colour is light greyish in ethanol. Cortex colour is light grey, choanosome colour is brown. Cortex is $0.7-1 \mathrm{~mm}$ thick. 105673 has a triangular fringe of spicules on its surface which could be a closed oscule (such as the ones we observed in a boreal species: Craniella zetlandica (Carter, 1872)). Thick sections of 105674 were made. Oxeas I (and few pro/anatriaenes) form large radial tight bundles that cross the ectosome. Many protriaenes, and fewer anatriaenes appear in the extension of these bundles, at the surface of the sponge, thus forming the hispidity. We also observe a double-layered cortex: (i) an upper-layer with a thin ectosome $(\sim 50 \mu \mathrm{m})$ made of large cells, and many sub-ectosomal canals, no spicules, (ii) a fibrous layer filled with a crisscross pattern of paratangential oxeas II. These oxeas II are absent in the choanosome. No embryos were observed in the thick sections.

\section{SPICULES, ZMBN 105674, UNLESS OTHERWISE}

STATED (FIGURE 22C-E)

Megascleres: (a) oxeas I, large, a bit thicker on one end (=anisoactinate), length: $2325-3587.8-4320 \mu \mathrm{m}(\mathrm{N}=16)$, width: $28-38.9-60 \mu \mathrm{m}(\mathrm{N}=16)$; (b) oxeas II, slightly bent or sometimes double bent, slightly anisoactinate, few are very slightly centrotylote, length: $470-690.8-840 \mu \mathrm{m}$, width: $20-28.5-36 \mu \mathrm{m}$; length: $550-713.2-850 \mu \mathrm{m}$, width: 25-29.3-32 $\mu \mathrm{m}$ (105673); (c) protriaenes (sometimes modified to prodiaenes), equal clads, clads are sometimes subdivided at their tips, whip-like end of rhabdome, rhabdome length: $4720-5805-6800 \mu \mathrm{m} \quad(\mathrm{N}=8)$, width: 28-32.1$40 \mu \mathrm{m}$, clads: $140-209.3-260 \mu \mathrm{m}$; (d) anatriaenes, rhabdome length more than $9800 \mu \mathrm{m}$, width: $8-10.4-12 \mu \mathrm{m}$, clads: 70$85.7-100 \mu \mathrm{m}$.

\section{BATHYMETRIC RANGE}

599-1650 m (Topsent, 1913; this study).

\section{DISCUSSION}

Our specimens agree well with the type material. The cortical oxeas II of the MAR-Eco specimens are slightly shorter and wider than in the lectotype (520-809.6-1010 × 18-23.8$32 \mu \mathrm{m})$. The only noticeable difference is that oxeas II in our specimens are slightly bent (or double bent in 105674) whereas they are very straight in both types. Topsent (1913) had noted that protriaenes could have irregular clads, we observed that these clads can even subdivide, as in the Balgim specimens (Boury-Esnault et al., 1994). As for the anatriaenes, their cladomes have an umbrella shape, similar to the ones found in the paralectotype (and not as open as in the 
lectotype). We observed spermatic cysts in the choanosome (sections of 105674, collected on 26 July 2004), but we did not observe embryos (in either specimen).

The MAR-Eco specimens greatly extend the northern distribution range for this species, until now only recorded from the Azores (Topsent, 1913, 1928) and the Ibero-Moroccan gulf (Balgim campaign) (Boury-Esnault et al., 1994). The MAR-Eco specimens were found in the same depth range as the Balgim specimens (1510 m).

Genus Tetilla Schmidt, 1868

Tetilla longipilis Topsent, 1904

(Figures $20 \mathrm{C} \& 23$ )

\section{MATERIAL}

One specimen from Station 40-367, $2961 \mathrm{~m}$ : ZMBN 105612. Two specimens from Station 42-368, $2078 \mathrm{~m}$ : 105616-17. Seven specimens from Station 50-373, 2600: ZMBN 105643.

\section{COMPARATIVE MATERIAL EXAMINED}

Tetilla longipilis, MOM-INV-22536 (04 0515), lectotype here designated, specimen represented by Topsent (1904, plate II), MOM-INV-22537 (04 0515), 12 paralectotypes, Azores, SE of Flores, Station 698, 39.18333, $-30.74444,1846 \mathrm{~m}$;
MNHN-DT880, slide of type material (not clear to which syntype it belongs); PC484, EMEPC2007, field\#D37A-Ma10, Plato Seamount, 33.1509, $-28.7905,1716 \mathrm{~m}$. Tetilla polyura, PC522, Ecosystem Barents Sea 2007 campaign, Station 2663, Barents Sea.

\section{OUTER MORPHOLOGY AND SKELETON}

ARRANGEMENT (FIGURE 23A-E)

Massive subspherical, up to $12 \mathrm{~cm}$ in diameter, highly hispid. Specimens (105643) have a long greyish and brownish 'fur' (Figure 23A, B). 105616 (Figure $23 \mathrm{C}$ ) is less hairy and has a large base made of spicules; it also has a small apical oscule. Pores not visible. Choanosome is light brownish in ethanol. Thick sections of 105616 (Figure 23D, E) and 105617 were done, revealing identical skeleton organizations. Oxeas I (and few pro/anatriaenes) form large radial tight bundles that cross the ectosome to form the typical 'fur'. Protriaenes and anatriaenes are very abundant in the 'fur', which is full of sediments. Just below the surface where sigmaspires tend to accumulate, there is a fibrous layer $120-200 \mu \mathrm{m}$ thick, where some anatriaenes can also be observed. Below, the choanosome is full of oxeas II sometimes paratangential to the surface (they do not form bundles), and sometimes without a particular orientation. Sigmaspires are also very common there.

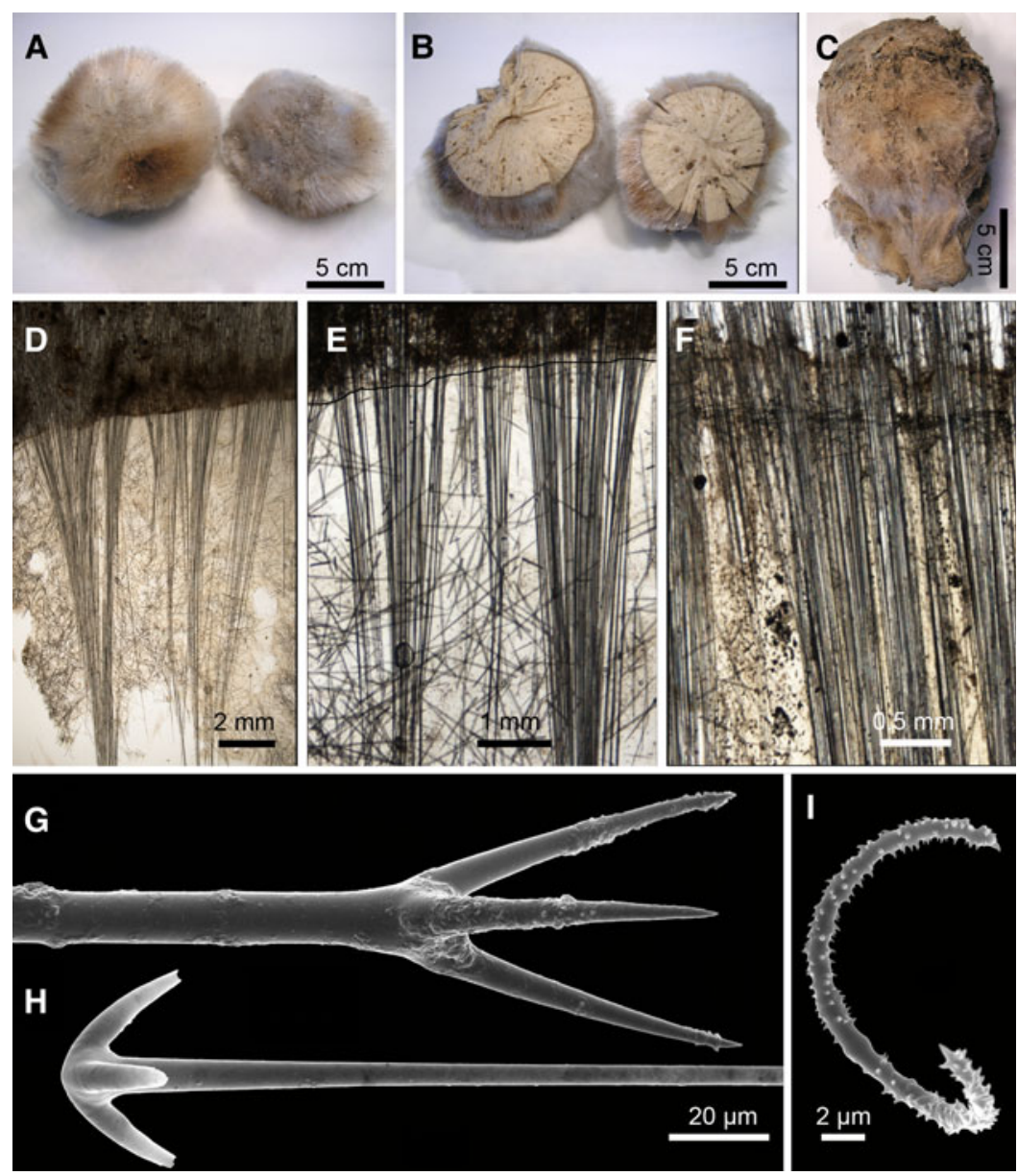

Fig. 23. Tetilla longipilis Topsent, 1904: $(A-B) Z M B N ~ 105643$ cut in half; (C) ZMBN 105617, notice the large base made of spicules only; the small single oscule is on the top (not visible on this picture); (D) Thick section from ZMBN 105617 showing the confused disposition of the oxeas II in the choanosome; (E) Close up of the ectosome in D. The fibrous layer lower boundary is shown with a drawn black line; (F) Thick section of lectotype MOM-INV-22536 showing the unusual criss-cross layer of oxeas II below the ectosome; (G) Protriaene (ZMBN 105617); (H) Anatriaene (ZMBN 105617); (I) Sigmaspire (ZMBN 105612). 
SPICULES, ZMBN 105616 (FIGURE 23G-I)

Megascleres: (a) oxeas I, large, a bit thicker on one end (= anisoactinate), length: $7650-10807.1-13250 \mu \mathrm{m}(\mathrm{N}=14)$, width: $60-84.6-100 \mu \mathrm{m} \quad(\mathrm{N}=14)$; (b) oxeas II, usually straight and rarely bent, both ends are equal (=isoactinate), some modified to styles, length: $410-831.5-1475 \mu \mathrm{m}$, width: 8.5-16.9-30 $\mu \mathrm{m}$; (c) protriaenes, rhabdome length: 660$3820-8650 \mu \mathrm{m} \quad(\mathrm{N}=18)$, width: $5-132.6-240 \mu \mathrm{m}$, clads 50-132.6-240 $\mu \mathrm{m}$; (d) anatriaenes, rhabdome length: $11000-11750-13250 \mu \mathrm{m} \quad(\mathrm{N}=3)$, width: 5-12.7-30 $\mu \mathrm{m}$, clads: $18-71.5-140 \mu \mathrm{m}$. Microscleres: (e) spiny sigmaspires, ' $s$ ' or ' $c$ ' shape, sometimes with a slight central swelling, length: $14-16.5-22.5 \mu \mathrm{m}$.

\section{BATHYMETRIC RANGE} 999-2960 m (this study).

\section{DISCUSSION}

This is only the second record of this species, if we exclude a record of Tetilla aff. longipilis (van Soest et al., 2007) which has been re-identified as Craniella sp. (P. Cárdenas, unpublished results). Along with this second record we bring additional boreal records from specimens we identified from the Danish-Ingolf Expedition 1895-1896 and BIOICE (both are ZMUC collections). Furthermore, we identified this species on pictures of specimens trawled in Hatton Bank (NW of Rockall Bank), and referred to as Craniella sp. (Durán Muñoz et al., 2009). Koltun (1966) was wrong in synonymizing T. longipilis with T. polyura Schmidt, 1870; they have clearly different external morphologies and spicule differences, so they are both valid species. Furthermore, T. longipilis is Lusitanian and boreal, T. polyura is an arctic species. We considerably extend the northern range of $T$. longipilis since we report it for the first time in boreal waters, thanks to specimens we identified in the Ingolf Expedition and BIOICE.

The external morphology and spicule measurements of the MAR-Eco specimens agree well with the type series described from the Azores. Our thick sections of 105616 and 105617 (Figure $23 \mathrm{D}, \mathrm{E}$ ) were compared with the ones we made from the lectotype (Figure $23 \mathrm{~F}$ ), collected in the Azores at $1846 \mathrm{~m}$ depth. The skeleton arrangements are similar but below the fibrous layer ( $300-400 \mu \mathrm{m}$ thick), the oxeas II in the lectotype are more regularly arranged and concentrated in a paratangential manner making a loose layer about $300 \mu \mathrm{m}$ thick. This layer is made of shorter oxeas II (around $600 \mu \mathrm{m}$ long) than the other oxeas II in the choanosome (around $1000 \mu \mathrm{m}$ long). Further observations of cross-sections in many specimens suggest that this layer of oxeas II, which makes a thin whitish layer visible to the naked eye, is more or less present depending on where the section is made. This layer is not characteristic of a Tetilla and reminds the microxea layer of Craniella species (Figure 23F). Another character that reminds of Craniella is the presence of embryos in the type series; however, they are bigger and less abundant than in Craniella species (Topsent, 1904). We did not find them in the MAR-Eco specimens, nor in the Ingolf and BIOICE material that we examined. Based on the presence of cortical oxeas, Lehnert \& Stone (2011) suggest the transfer of this species to Craniella but the thick sections made on the lectotype and the MAR-Eco specimens clearly show that even though T. longipilis has a denser arrangement of oxeas II below its fibrous layer, it has no true double-layered cortex, as in other Craniella species sensu Sollas (1888) (cf. description of Craniella azorica). So in our opinion, although this species might represent an evolutionary intermediate step between Tetilla and Craniella, we propose to keep it in Tetilla until additional data are obtained, and a revision of Tetilla and Craniella is made.

\section{Tetilla sandalina Sollas, 1886}

(Figures 20D \& 24)

\section{MATERIAL}

One specimen from 44-369, $1742 \mathrm{~m}$ : ZMBN 105626.

\section{COMPARATIVE MATERIAL EXAMINED}

Tetilla polyura, PC522, Ecosystem Barents Sea 2007 campaign, Station 2663, Barents Sea; ZMUC, Godthaab Expedition 1928, off Labrador, 55, $-56.56667,314 \mathrm{~m}$, original det. by Brøndsted (1933) as Tetilla sandalina.

OUTER MORPHOLOGY (FIGURE 24A)

This is a small fragment of a larger sponge. No cortex is visible. A large spicule tuft is present on the surface which could represent an oscule.
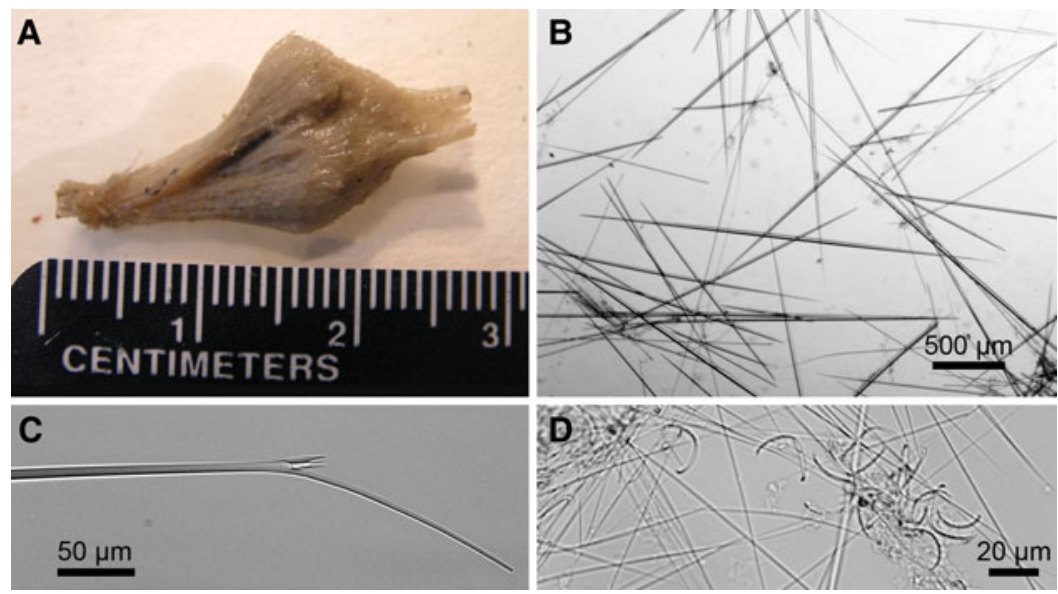

Fig. 24. Tetilla sandalina Sollas, 1886, ZMBN 105626: (A) Specimen; (B) Oxeas I; (C) Protriaene; (D) Sigmaspires and raphid-like oxeas III. 
SPICULES, ZMBN 105626 (FIGURE 24B, D) Megascleres: (a) oxeas I, large, a bit thicker on one end (=anisoactinate), length: $1210-2124.3-2900 \mu \mathrm{m}$, width: 14.5-22.2-30 $\mathrm{m}$; (b) oxeas II, straight or slightly bent, both ends are equal (=isoactinate), length: 580-658.6$785 \mu \mathrm{m}$, width: $15-17.1-20 \mu \mathrm{m}$; (c) oxeas III, raphide-like, flexuous, $242-250 \mu \mathrm{m}$, width: $2-3 \mu \mathrm{m}$; (d) protriaenes, rhabdome with a whip-like end, rhabdome length: 1300-1967.6$3200 \mu \mathrm{m}(\mathrm{N}=17)$, width: $2.5-5.2-7.5 \mu \mathrm{m}$, unequal cladome with two small clads and a much longer one, small clads: 524.3-40 $\mu \mathrm{m}$, longer clad: 52-160.4-225 $\mu \mathrm{m}$. Microscleres: (e) sigmaspires, 's' or ' $c$ ' shape, length: 15-19.7-25 $\mu \mathrm{m}$, width: $1 \mu \mathrm{m}$.

\section{BATHYMETRIC RANGE}

1742-1818 m (Sollas, 1888; this study).

\section{DISCUSSION}

We do not have a complete specimen but it is still enough to confirm the validity of this species. Indeed, both Topsent (1923) and Koltun (1966) suggest that T. sandalina is a synonym of $T$. polyura but after examining both species, we conclude that, although they are obviously morphologically close, they are clearly distinct. They both share the typical ' 2 short clads +1 long clad' protriaene cladome and the raphide-like oxeas (called 'trichodal oxeas' by Sollas (1888)) but in $T$. sandalina, the sigmaspires are not centrotylote as in T. polyura. Furthermore, as in the original description, we could not find any anatriaenes (whereas they are very commonly found in T. polyura). One difference with the original description is that Sollas (1888) reports that one or both of the shortest clad can disappear; we have not observed this in our specimen. This is only the second record of this species, originally collected at a similar depth $(1818 \mathrm{~m})$ in the Azores during the Challenger expedition. We examined the ZMUC specimen of $T$. sandalina collected off Labrador (314 $\mathrm{m}$ depth) from Brøndsted (1933) and re-identified it as T. polyura (it has centrotylote sigmaspires, smaller than in T. sandalina: $12-15 \mu \mathrm{m}$ ); this is not surprising since T. polyura has been recorded in the Flemish Cap at similar depths (F. J. Murillo, personal communication).

Order POLYMASTIIDA Morrow \& Cárdenas, 2015 Family POLYMASTIIDAE Gray, 1867

Genus Polymastia Bowerbank, 1864

Polymastia corticata Ridley \& Dendy, 1886

(Figures 25 \& 26)

\section{MATERIAL}

One specimen from 70-385, $1650 \mathrm{~m}$ : ZMBN 105663.

\section{COMPARATIVE MATERIAL EXAMINED}

ZMBN 98097, Flemish Cap, 47.072323, -43.449141, NEREIDA 0509, Station DR20-67, 1113-1122 m, det. A. Plotkin; ZMBN 98104, Orphan Knoll (north of Flemish Cap), HUD2010-029, ROV dive R1341-16, 50.077259, $-45.618838,2390-2873 \mathrm{~m}$, det. A. Plotkin; ZMBN 98105, Closs Seamount, south of Azores, 29.35343, - 29.14605, EMPC/LUSO 2009, Station EMEPC/G3/09.34, 1086 m, det. A. Plotkin.

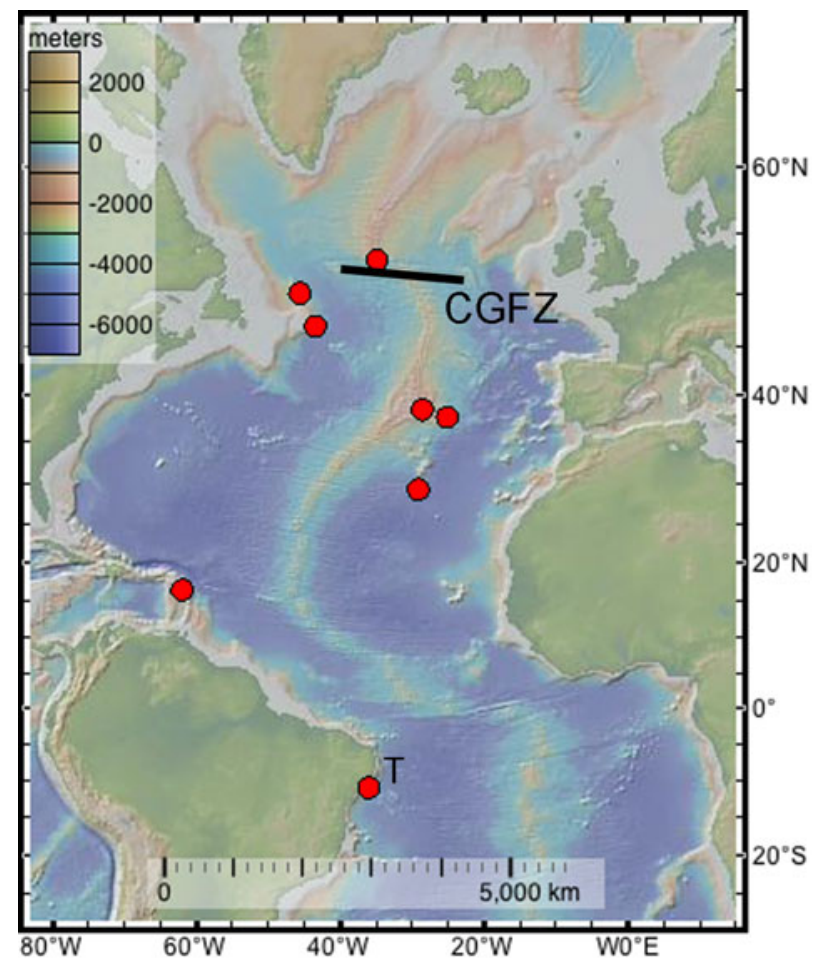

Fig. 25. Distribution map of Polymastia corticata Ridley \& Dendy, 1886. T, type locality; CGFZ, Charlie-Gibbs Fracture Zone. Map generated with GeoMapApp 3.3 (http://geomapapp.org).

\section{OUTER MORPHOLOGY AND SKELETON}

ORGANIZATION (FIGURE 26A, B)

Massive cushion-shaped specimen. Surface is nearly smooth, with exhalant and inhalant papillae of different sizes, irregularly distributed. Colour of the surface, papillae and choanosome is pale pink in alcohol. Cortex dense, leathery, easy detachable. Choanosome friable. Exhalant papillae conical, slightly flattened, $2.8 \mathrm{~mm}$ in basal diameter and $0.4 \mathrm{~mm}$ in apical diameter. Inhalant papillae are nearly cylindrical. Main choanosomal skeleton is a reticulation of bundles of principal styles. Additional choanosomal skeleton made by free-scattered intermediary styles. The cortex is $2 \mathrm{~mm}$ thick, made of two overlapping layers: the external palisade of small styles and the internal confused and dense mass of intermediary styles mixed with small styles.

SPICULES, ZMBN 105663 (FIGURE 26C-E)

Megascleres: (a) principal styles, length: 1128-1470-1704 $\mu \mathrm{m}$ ( $\mathrm{N}=13$ ), width: $18.2-21.1-25.1 \mu \mathrm{m}(\mathrm{N}=13)$; (b) intermediary styles, length: $549-850-1032 \mu \mathrm{m}$, width: $13.7-19.1-$ $22.8 \mu \mathrm{m}$; (c) small cortical tylostyles, length: 119-187$419 \mu \mathrm{m}$, width: $2.3-5.4-14.8 \mu \mathrm{m}$.

\section{BATHYMETRIC RANGE}

1113-2390 m (this study).

\section{DISCUSSION}

The type locality of P. corticata is in the South-West Atlantic, between Pernambuco and Bahia (Figure 25), at $2194 \mathrm{~m}$ depth, and yet our specimen very closely matches this species. Similar connections between the northern MAR and the South-West Atlantic have been reported for deep-sea Hexactinellida 

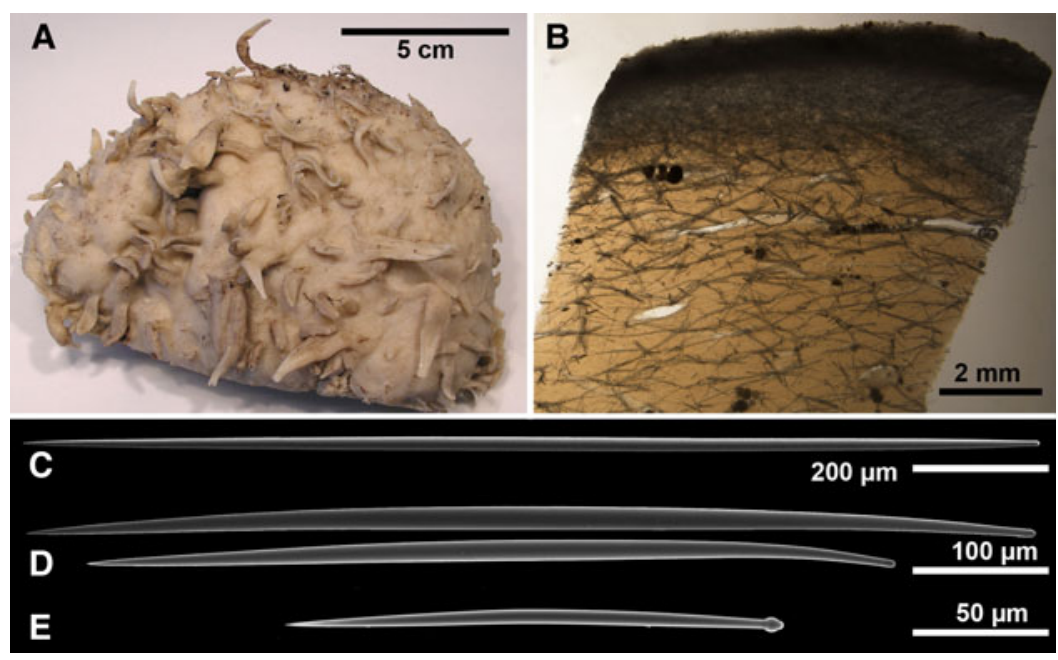

Fig. 26. Polymastia corticata Ridley \& Dendy, 1886, ZMBN 105663: (A) Specimen; (B) Thick section; (C) Principal styles; (D) Intermediary styles; (E) small cortical tylostyles.

(Lopes \& Tabachnick, 2013). The specimens described by Topsent $(1892,1904)$ in the Azores are similar although he reports only one type of papillae. The specimen SMF 9633 (Lesser Antilles, Kahouanne Basin, $1127 \mathrm{~m}$ ) was identified by D. Janussen (Meyer \& Kuever, 2008); we did not examine this specimen but its $28 \mathrm{~S}\left(\mathrm{D}_{1}-\mathrm{D}_{2}\right)$ sequence (GenBank\#EU005552) groups with the sequences of other identified P. corticata (A. Plotkin, personal communication).

Order SUBERITIDA Chombard \& Boury-Esnault, 1999 Family STYLOCORDYLIDAE Topsent, 1892

Genus Stylocordyla Thomson, 1873

Stylocordyla borealis (Lovén, 1868)

(Figures 27 \& 28)

\section{MATERIAL}

One specimen from 50-373, $2600 \mathrm{~m}$ : ZMBN 105647.

\section{COMPARATIVE MATERIAL EXAMINED}

GNM-Spongiaria 188, Vanvik, Trondheimsfjord, coll. L. A. Jägerskiöld; GNM-Spongiaria 207, Skagerrak, Station 133, $58^{\circ} 30.671^{\prime} \mathrm{N} \quad 10^{\circ} 04.452^{\prime} \mathrm{E}, 556 \mathrm{~m}$, coll. L. A. Jägerskiöld; GNM-Spongiaria 808, Skagerrak, 2006, SK25, $58^{\circ} 29.002^{\prime} \mathrm{N}-$ $58^{\circ} 28.351^{\prime} \mathrm{N} 10^{\circ} 08.391^{\prime} \mathrm{E}-10^{\circ} 07.642^{\prime} \mathrm{E}, 500-509 \mathrm{~m}$.

\section{OUTER MORPHOLOGY (FIGURE 28A)}

Typical pedunculate shape with long stalk. One osculum ( $3 \mathrm{~mm}$ in diameter), surrounded by a spicule fringe, is present on the upper side of a conical body. The head is somewhat flattened on top (length of head: $2 \mathrm{~cm}$ ). Length of stalk: $9 \mathrm{~cm}$. Brown in ethanol.

SPICULES, ZMBN 105647 (FIGURE 28B-E)

Megascleres: (a) oxeas I, straight, usually slightly centrotylote, length: $776-1011-1367 \mu \mathrm{m}(\mathrm{N}=23)$, width: 10.4-14.8$20.8 \mu \mathrm{m}(\mathrm{N}=23)$. (b) oxeas II, more or less centrotylote, straight to slightly bent, some are asymmetrical with a sharp bent, length: 316-503-684 $\mu \mathrm{m}$, width: 3.9-5.7-10.4 $\mu \mathrm{m}$. (c) microxeas, some are faintly centrotylote, usually straight, length: $80-93-116 \mu \mathrm{m}$, width: $2.3-3.2-4.6 \mu \mathrm{m}$. Spicules were sampled from the body and stalk.

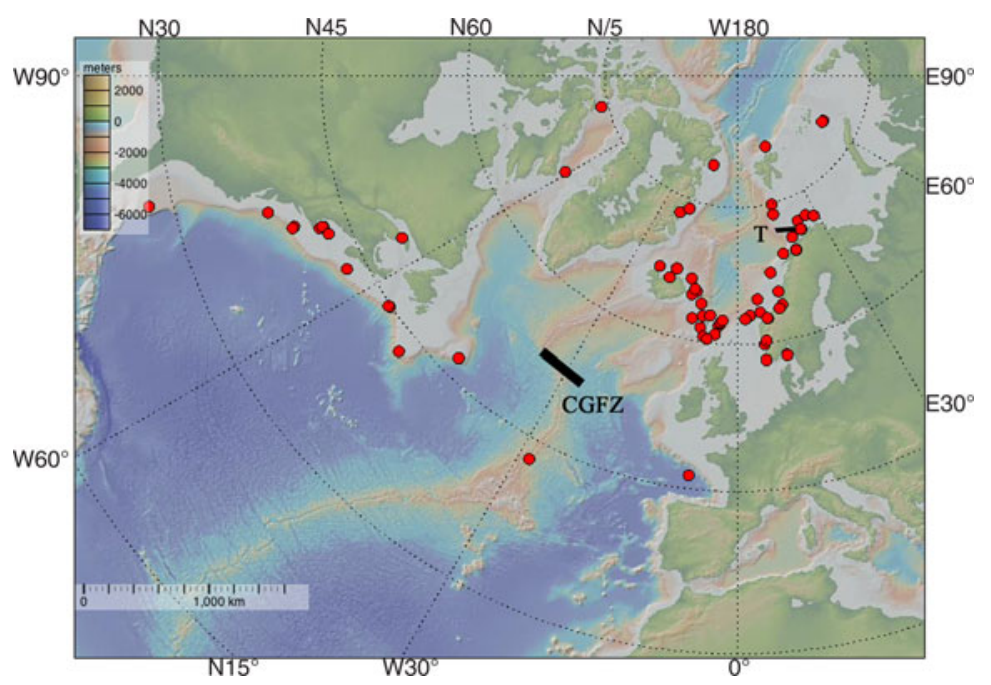

Fig. 27. Distribution map of Stylocordyla borealis (Lovén, 1868). T, type locality; CGFZ, Charlie-Gibbs Fracture Zone. Map generated with GeoMapApp 3.3 (http://geomapapp.org). 


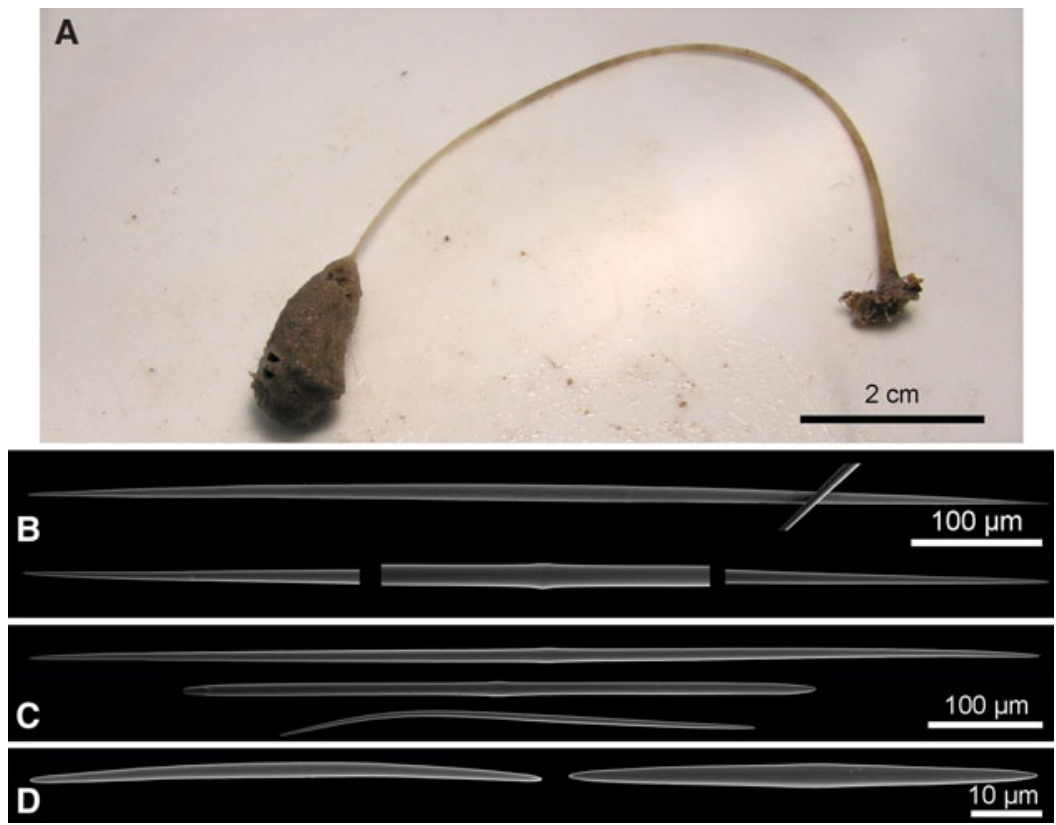

Fig. 28. Stylocordyla borealis (Lovén, 1868), ZMBN 105647. (A) Specimen; (B) Oxeas I; (C) Oxeas II; (D) Microxeas.

BATHYMETRIC RANGE

$22-2600 \mathrm{~m}$ (this study).

\section{DISCUSSION}

This specimen's morphology agrees well with the redescription of the species and the type material (Uriz et al., 2011). The only difference we note is that the osculum is not present on the top surface but it is slightly off to the side, as in Stylocordyla longissima Sars, 1872, a species later synonymized with S. borealis (Hansen, 1885; Vosmaer, 1885;
Arndt, 1913). This species is widespread across the deep North Atlantic boreo-arctic region, on either side of the Atlantic. However, this is its first record in the Azores region. Many GBIF (www.gbif.org) records (from the Yale Peabody Museum, material not seen) suggest that this species is very common on the eastern US coast shelf down to the Bahamas (Figure 27). Schmidt (1880) also recorded this species from Grenada $(290 \mathrm{~m})$. We found a specimen from Ólafsfjörður (Iceland, BIOICE campaign, Station 2193) collected at only $18-22 \mathrm{~m}$ depth, which is the shallowest record for this species. The dubious identity of the small $S$.

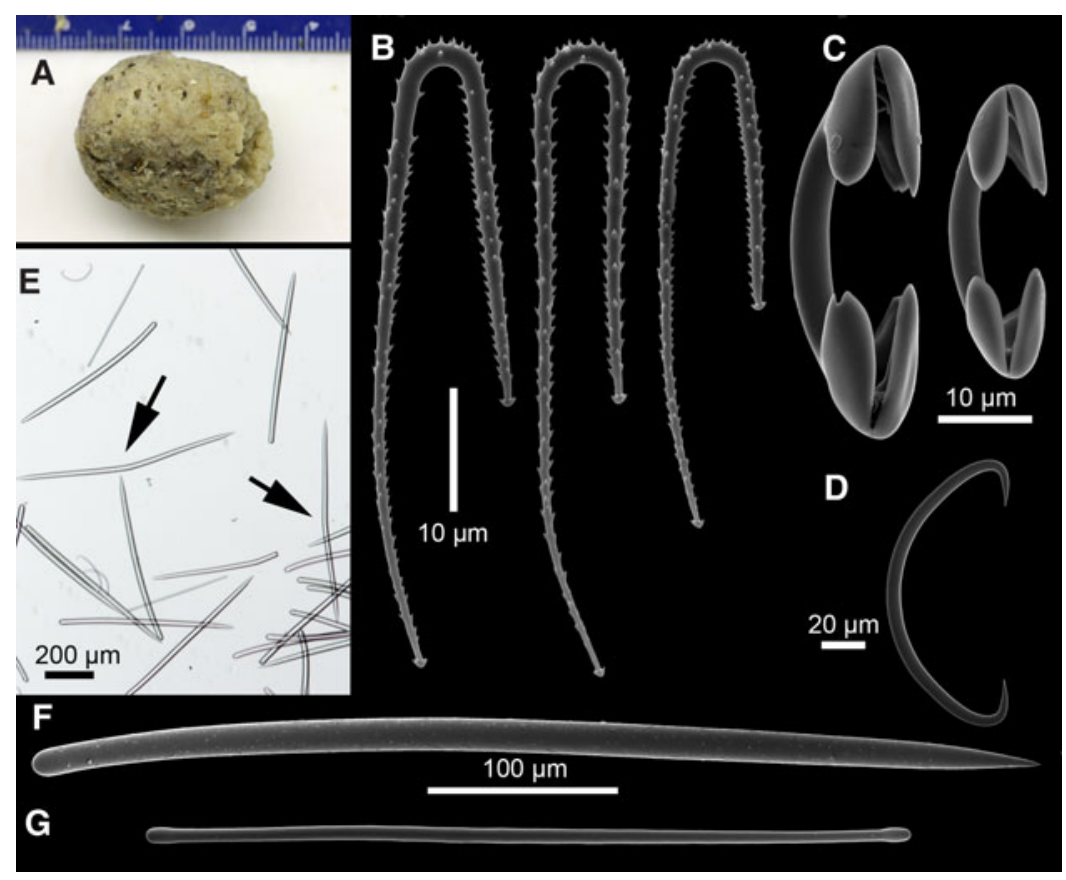

Fig. 29. Forcepia (Forcepia) toxafera sp. nov., holotype, ZMBN 105651: (A) Holotype; (B) Forceps; (C) Chelae; (D) Sigma; (E) Styles, sigmas and oxeote toxas (arrows); (F) Style; (G) Tylote. 
borealis specimen (BMNH.1882.7.28.73) collected off Bahia (Brazil) at only $12-36 \mathrm{~m}$ depth by the Challenger (Ridley \& Dendy, 1887) would need to be revised.

Order POECILOSCLERIDA Topsent, 1928 Family COELOSPHAERIDAE Dendy, 1922 Genus Forcepia Carter, 1874

Forcepia (Forcepia) toxafera sp. nov. (Figure 29, Table 3)

TYPE MATERIAL

Holotype: ZMBN 105651, Station 52-374 (42.922, $-28.13917), 2977 \mathrm{~m}$

\section{COMPARATIVE MATERIAL EXAMINED}

Forcepia (Forcepia) toxafera sp. nov., MOM INV-22577 (04 0497), Station 673, 37.85, -26.9, Azores, $2252 \mathrm{~m}$, original det. as Trachyforcepia groenlandica by Topsent (1904). Forcepia (Forcepia) groenlandica (Fristedt, 1887), SNHM-Type-8629 (wet specimen), SNHM-113069 (slide), holotype, east coast of Greenland, number 579, Sofia Expedition to Greenland 1883, $228 \mathrm{~m}$. Forcepia (Forcepia) thielei (Lundbeck, 1905), ZMUC-DEM-171 (slide), syntype, Ingolf Expedition Station 73, South of Iceland, 62.96667, $-23.46667,915 \mathrm{~m}$.

\section{OUTER MORPHOLOGY (FIGURE 29A)}

Massive subspherical, $3 \mathrm{~cm}$ in diameter, fairly compressible, slightly velvety surface, mixed with sand and bivalve debris, whitish in ethanol.

\section{SPICULES (FIGURE 29B-G)}

Megascleres: (a) styles, slightly bent, very often with a stronger bent below the blunt end, completely smooth or with very few spines (1-3), length: 622-684-735 $\mu \mathrm{m}$, width: 10-25$29 \mu \mathrm{m}$. (b) oxeote toxas, less common than styles, smooth, rarely modified to oxeas, length: 770-857.6-920 $(\mathrm{N}=17)$, width: $20-22-25 \mu \mathrm{m}(\mathrm{N}=17)$. (c) tylotes, length: 413486-520 $\mu \mathrm{m}$, width: $7.8-9.9-10.4 \mu \mathrm{m}$, tyle: 9.1-10.3$13.0 \mu \mathrm{m}$. Microscleres: (d) arcuate isochelae, length: 22-37.9-55 $\mu \mathrm{m}$, shaft (side view): $2.5-4.5 \mu \mathrm{m}$. (e) sigmas, very common, plane, 'C' shaped, more rarely 'S' shaped, hookshaped ends, rarely one of the ends is divided in two (seen 3 ), length: $105-125.2-175 \mu \mathrm{m}$, width: $5-7 \mu \mathrm{m}$. (f) forceps, not common, length of long branch: $43-52.8-65 \mu \mathrm{m}(\mathrm{N}=11)$, length of short branch: $25 \cdot 7-30.4-35 \mu \mathrm{m}(\mathrm{N}=20)$.

\section{ETYMOLOGY}

This species is named after the large oxeote toxas: 'toxafera' means 'that carries toxas'.

\section{BATHYMETRIC RANGE}

2252-2977 m (Topsent, 1904; this study).

\section{DISCUSSION}

The spicule assemblage of the MAR-Eco specimen is quite similar to the one found in Forcepia (Forcepia) groenlandica and Forcepia (Forcepia) thielei, respectively described from the east coast and from the west coast of Greenland. Both type materials were re-examined for this study and we also made new spicule preparations from the type of $F$. (F.) groenlandica. Actually, our specimen is even closer to the specimen

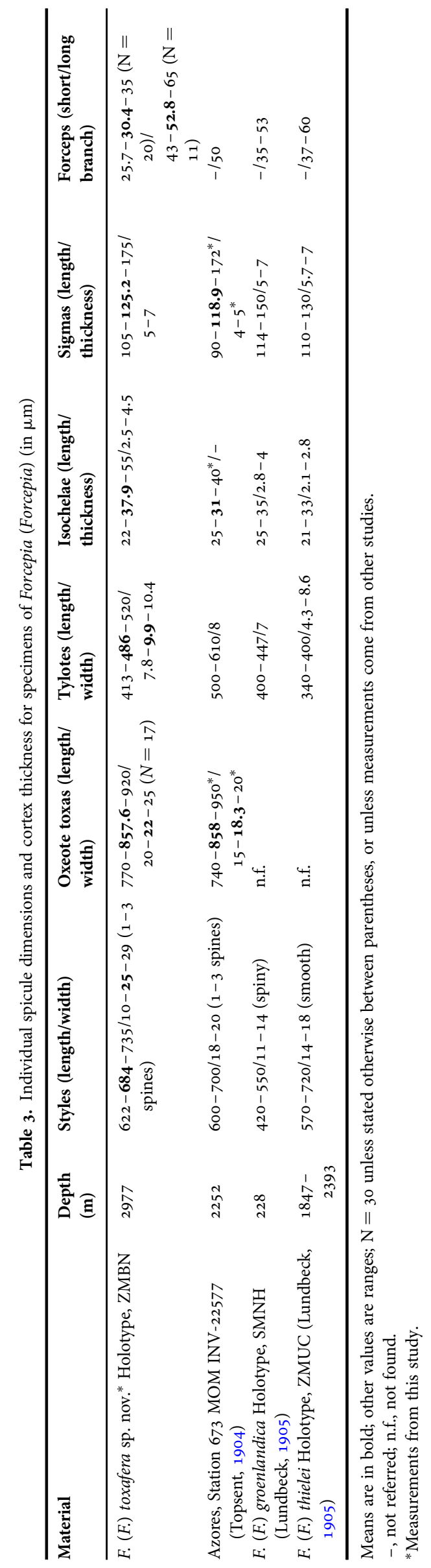




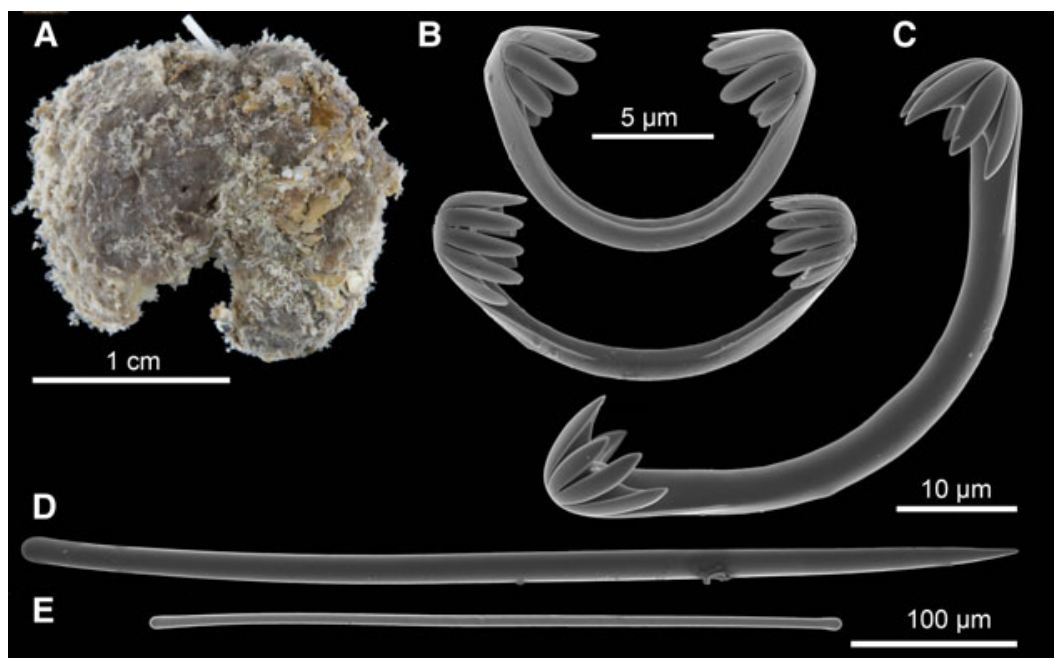

Fig. 3o. Iotroata paravaridens sp. nov., holotype, ZMBN 105615: (A) Holotype; (B) Chelae II; (C) Chelae I; (D) Styles; (E) Tylote.

described by Topsent (1904) under the name F. (F.) groenlandica, and collected at great depths $(2252 \mathrm{~m})$ in the Azores. Topsent's specimen and ours are clearly conspecific (Table 2) and differ from F. (F.) groenlandica: (i) the styles are larger, (ii) the sigmas of our specimens are plane ( $v s$ more or less contorted), (iii) the styles are smooth with occasional spines ( $v s$ fairly spiny) and (iv) there are large oxeote toxas, absent in F. (F.) groenlandica. The nearly smooth styles also make $F$. (F.) toxafera sp. nov. close to the Arctic species $F$. (F.) thielei but there are differences: (i) the styles can have a few spines ( $v s$ no spines at all in $F$. (F.) thielei), (ii) the forceps of our specimen are less densely spined, (iii) the short branches of the forceps are straight ( $v s$ bent in F. (F.) thielei), and again (iii) there are oxeote toxas. All these differences support the creation of a new species, named after the large oxeote toxas. These toxas were overlooked by Topsent (1904) but we found them to be common (albeit in lower numbers than the styles) when we re-examined his specimen (MOM INV-22577).

After $F$. (F.) groenlandica and $F$. (F.) thielei, $F$. (F.) toxafera sp. nov. is the third species of Forcepia with a single category of forceps, which are asymmetrical. There are three other North Atlantic Forcepia species with asymmetrical forceps but they also have another category of larger symmetrical forceps: Forcepia (Leptolabis) brunnea (Topsent, 1904), F. (L.) assimilis (Lundbeck, 1910) and F. (L.) forcipula (Topsent, 1904). Forcepia (L.) brunnea and F. (L.) assimilis may actually be the same species according to Topsent (1928).

\section{Family IOTROCHOTIDAE Dendy, 1922 \\ Genus Iotroata de Laubenfels, 1936 \\ Iotroata paravaridens sp. nov. \\ (Figure 30)}

TYPE MATERIAL

Holotype: ZMBN 105615, Station 40-367 (42.91667, -30.33333 ), $2961 \mathrm{~m}$.

OUTER MORPHOLOGY (FIGURE 3OA)

Small subspherical, and presumably complete specimen (1.5 cm in length); brownish, full of debris and sand.
SPICULES (FIGURE 3OB-E)

Megascleres: (a) styles, smooth, straight to very slightly curved, length: $546-612-673 \mu \mathrm{m}$, width: $6.5-16.6-23.4 \mu \mathrm{m}$. (b) tylotes (the swellings of the ends can be very faint but are always present), straight, length: $367-401-454 \mu \mathrm{m}$, width: 5.2-7.0-9.1 $\mu \mathrm{m}$, tyle: 6.5-7.9-9.1 $\mu \mathrm{m}$. Microscleres: (c) unguiferous chelae I with 5-6 pointy teeth, length: $49-58-68 \mu \mathrm{m}$, alae span: 7.8-10.1-13.0 $\mu \mathrm{m}$, shaft: 3.9-4.5-5.2 $\mu \mathrm{m}$. (d) polydentate chelae II, with shaft more or less strongly bent, 7-9 teeth with sub-rounded ends, length: $14-20-25 \mu \mathrm{m}$, shaft (side view): $1.3 \mu \mathrm{m}$, alae span: $5.2-8.0-10.4 \mu \mathrm{m}$.

\section{ETYMOLOGY}

This species is named 'paravaridens' to underline its presumed phylogenetic affinities with the Arctic species Iotroata varidens.

\section{DISCUSSION}

According to their definition, Iotrochotidae species should have birotula microscleres (van Soest, 2002). However, our new species does not have birotulas but two sizes of anchorate chela. We nonetheless decide to allocate this species to the genus Iotroata for the following reasons: (1) the spicule repertoire of this species closely matches that of other Iotroata species (smooth styles, tylotes and unguiferous chelae) and (2) birotulas are probably derived from anchorate chelae (van Soest, 2002). So we consider here that the smaller size of anchorate chelae in our new species is homologous to the small category of birotulas in other Iotroata species. Furthermore, this new species is very similar with respect to spicule morphology and sizes to Iotroata varidens (Lundbeck, 1910), a deep-sea species described from the Denmark Strait at $567 \mathrm{~m}$ depth. The main difference between the two species is the presence of birotulas in I. varidens (size of birotulas: 15-21 $\mu \mathrm{m}$ ) vs polydentate anchorate chela in $I$. paravaridens (size of chela: $14-25 \mu \mathrm{m}$ ).

Subclass KERATOSA Grant, 1861 Order DENDROCERATIDA Minchin, 1900 Family DICTYODENDRILLIDAE Bergquist, 1980

Genus Spongionella Bowerbank, 1862

Spongionella aff. pulchella (Sowerby, 1806) (Figure 31) 

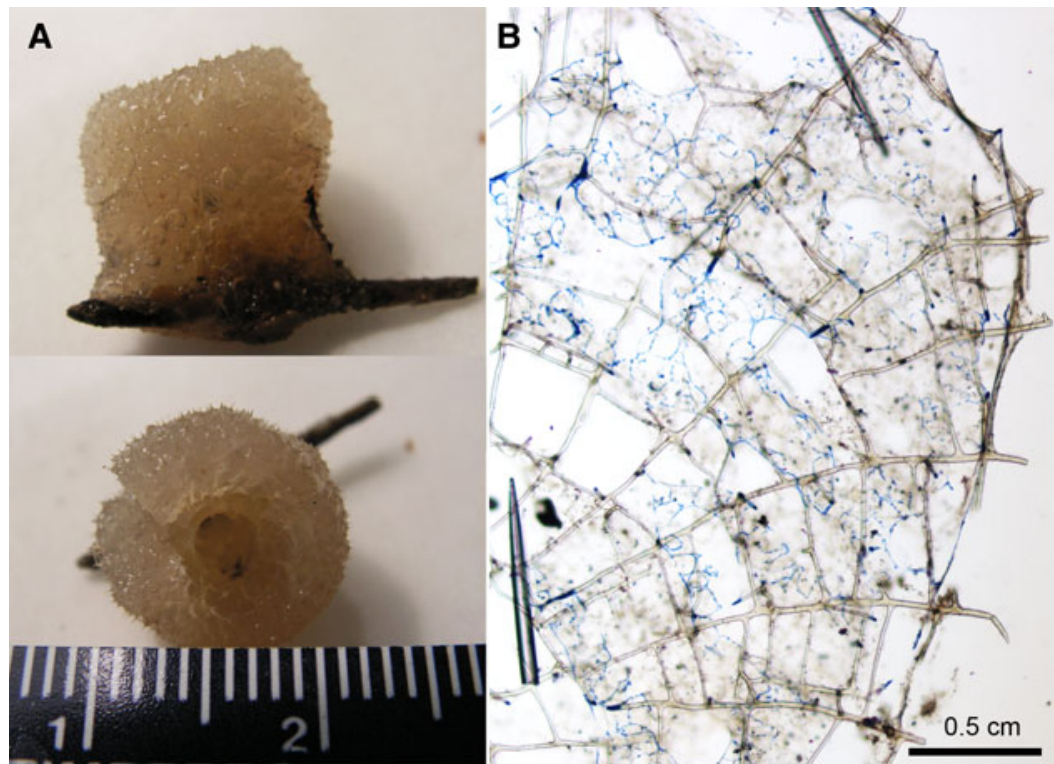

Fig. 31. Spongionella aff. pulchella (Sowerby, 1806), ZMBN 105658: (A) Specimen; (B) Thick section lightly stained with toluidine blue showing the network of fibres.

MATERIAL

One specimen from 53-375, Faraday Seamount, $990 \mathrm{~m}$ : ZMBN 105658.

\section{COMPARATIVE MATERIAL EXAMINED}

Spongionella pulchella, GNM-Spongiaria-801, 803, 804, Svenska Artprojecket, Swedish West coast; Spongionella sp., Ifremer Caracole 2001, specimen K14h, Rockall Bank, $867 \mathrm{~m}$; Spongionella sp., GNM-Spongiaria-802, Svenska Artprojecket, Swedish West coast; Spongionella gracilis (Vosmaer, 1883), 209S, personal collection of J. Vacelet (Endoume Marine Station, Marseille), Cap Kavensur, Tunisia, $37 \mathrm{~m}$.

OUTER MORPHOLOGY AND SKELETON (FIGURE 31A) Small whitish cup-shaped specimen with a conulose surface. Specimen is $2 \mathrm{~cm}$ in diameter with a single oscule $\left(\sim_{3} \mathrm{~mm}\right.$ in diameter). Very regular network of primary and thinner perpendicular secondary fibres, pale yellow in colour. Distance between primary fibres is $550-1150 \mu \mathrm{m}$ long. A few tertiary fibres interconnect secondary fibres. Fibres are stratified (no distinct pith observed). Eurypylous chambers are large, usually more than $100 \mu \mathrm{m}$ in length and up to $190 \mu \mathrm{m}$. Twelve embryos ( $200 \mu \mathrm{m}$ in diameter each) were observed in the choanosome of the sections.

\section{FIBRES (FIGURE 31B)}

(a) Primary fibres, stratified, 27-45 $\mu \mathrm{m}$ wide, length of extension beyond surface: $250-400 \mu \mathrm{m}$, (b) secondary fibres, stratified, 12-20 $\mu \mathrm{m}$ wide, (c) tertiary fibres, more rare, around $10 \mu \mathrm{m}$.

\section{DISCUSSION}

Four species of Spongionella are recorded from the North-East Atlantic/Mediterranean area: S. pulchella (Sowerby, 1806), S. gracilis (Vosmaer, 1883), S. ramodigitata (Topsent, 1901) and $S$. depressa Topsent, 1929. Based on our measurements of the primary and secondary fibres and on the external morphology, our specimen is closer to S. pulchella. But the distance between the primary fibres $(550-1150 \mu \mathrm{m})$ is much bigger than usual $(200-350 \mu \mathrm{m})$, which is a character found in $S$. depressa. Moreover, $S$. pulchella is usually found between 40 and $380 \mathrm{~m}$, the deepest record being off Monaco (Vacelet, 1969). So we tentatively identify this specimen as S. aff. pulchella, while waiting for additional specimens from this area and a revision of this group in the North Atlantic/ Mediterranean Sea which should test if North Atlantic and Mediterranean populations are conspecific and if deep-sea and shallow $S$. pulchella are conspecific. While investigating Spongionella species, we came across the description of Spongionella brandtii (Miklucho-Maclay, 1870) from the Sea of Okhotsk (Arctic Pacific), currently a synonym of $S$. pulchella according to previous authors (von Lendenfeld, 1888; Koltun, 1959). But $S$. brandtii has a characteristic smooth foliaceous shape (termed 'discoidal' by Koltun) with concentric trenches (Koltun, 1959, plate 41), whereas S. pulchella is often a rather thick lamella with a minute conulose surface (not smooth). We suggest that $S$. brandtii type material should be re-examined carefully because we suspect this species to be valid.

\section{DISCUSSIDN}

We have identified in the MAR-Eco collection 22 species of Demospongiae, two of which are new for science (Table 1): Forcepia (Forcepia) toxafera sp. nov. and Iotroata paravaridens sp. nov. Seventeen out of the 22 belong to the Tetractinellida order, a group thought to have originated in the deep sea (Cárdenas et al., 2011). In comparison, 16 species of Hexactinellida sponges were identified in the MAR-Eco material with 13 species new for science (Menshenina et al., 2007; Tabachnick \& Menshenina, 2007; Tabachnick \& Collins, 2008). Only one specimen of Calcarea sponge was found in the MAR-Eco collection: a new calcaronean species (to be described). Station 50 (north of the Azores) was the richest in terms of demosponge 
species and biomass: eight species (including four Geodia species) and 24 specimens indicating a sponge ground in this area. Station 70 (north-west of the CGFZ) was also fairly diverse with seven species and 13 specimens. Station 70 actually had the highest diversity of Hexactinellida with nine species identified (Gebruk et al., 2010). Overall, Station 70 (at the southern tip of Reykjanes Ridge) had not only the highest sponge diversity, but also the highest benthic species richness (Gebruk et al., 2010).

\section{The MAR is not a longitudinal barrier for deep-sea demosponges}

According to our distribution maps (Figures 2, 13, 20, 25 \& 27 ), $68 \%$ of the MAR-Eco species (15 species out of the 22) are amphi-Atlantic. We further note that both boreo-arctic species (with distributions north of the CGFZ) and Lusitanian species (with distributions south of the CGFZ) can be amphi-Atlantic. Although Tetilla longipilis has been essentially collected on the MAR, apart from a record in Hatton Bank (NEA), we have identified specimens collected in the Denmark Strait and on the western side of the MAR so it is likely present further west, and we suspect it to be a true amphi-Atlantic species. Since this is a poorly known species it could have easily been overlooked in the NWA. On other hand, Poecillastra compressa seems genuinely restricted to the NEA and the MAR, since it has numerous records and is a relatively easy species to identify. The rest of the NEA-restricted species are either new species (I. paravaridens sp. nov., $F$. (F.) toxafera sp. nov.) or poorly known deep-sea species (i.e. with very few records) with distribution ranges south of the CGFZ (C. azorica, T. sandalina, $S$. aff. pulchella). Therefore these species might very well be amphi-Atlantic but for now they are considered restricted to the NEA and/or the MAR. $68 \%$ of amphi-Atlantic sponge species is well in agreement with a faunistic review showing that $61 \%$ of the 80 species collected in the Reykjanes Ridge (Madreporaria, Cirripedia, Echinoidea, Asteroidea and Brachiopoda), north of the CGFZ, were amphi-Atlantic (Mironov \& Gebruk, 2006). The conspecificity of boreo-arctic amphi-atlantic Geodia species has been further confirmed with genetic data (Cárdenas et al., 2013). Seemingly, the status of the amphi-Atlantic MAR-Eco species found south of the CGFZ would need to be tested with genetic data. To conclude, the high proportion of amphi-Atlantic species suggest that the MAR is not a barrier to the dispersal of deep-sea Demospongiae. On the contrary, deep-sea demosponges may use the MAR and neighbouring continental margins to disperse at bathyal depths, to avoid the much deeper abyssal depths (i.e. large abyssal basins) where they are absent (Figures 2, 13, 20, 25 \& 27).

\section{The CGFZ, a potential latitudinal border for deep-sea demosponges}

Some MAR-Eco species are restricted to the boreal and/or Arctic waters and thus stay north of the CGFZ: Stelletta rhaphidiophora, Geodia macandrewii, Geodia phlegraei, Thenea levis. Other MAR-Eco species are restricted to Lusitanian waters and thus stay south of the CGFZ or at the most on the northern part of the CGFZ: Geodia nodastrella, Thenea schmidti, Craniella azorica, Tetilla sandalina. Finally, eight species can be found north and south of the CGFZ: Geodia atlantica, Geodia hentscheli, Stelletta tuberosa, Stryphnus fortis, Poecillastra compressa, Thenea valdiviae, Tetilla longipilis and Stylocordyla borealis. This is not surprising since most (65\%) of the species identified during a study in the Reykjanes Ridge had distribution ranges further south than $52^{\circ} \mathrm{N}$ (Mironov \& Gebruk, 2006). However, in the case of five out of these eight species, our study showed that the MAR southern populations (i.e. south of the CGFZ) were somehow morphologically different from the northern populations. Southern populations of G. atlantica, G. hentscheli, T. valdiviae, $S$. fortis and $P$. compressa had clear external morphology and/or spicule differences. More specimens from this area as well as genetic data are now required to confirm these observations and test if these southern populations represent sister-species. Actually, T. schmidti is probably another example of this since it may represent a southern sister-species of T. muricata, hence our difficulty to discriminate them morphologically. Genetically, the mitochondrial cytochrome oxidase I (COI) Folmer fragment is not enough to differentiate these two populations but the $28 \mathrm{~S}\left(\mathrm{C}_{1}-\mathrm{D}_{2}\right)$ marker is more promising (Cárdenas \& Rapp, 2012). Likewise, $F$. (F.) toxafera sp. nov. and $I$. paravaridens sp. nov. are probably sister species of more northern Greenland species, respectively $F$. (F.) groenlandica and I. varidens. Overall, these observations suggest that the CGFZ area represents a major biogeographic barrier for deep-sea demosponges, which limits gene flow between northern and southern populations. This barrier is not limited to the two deep fractures per se (about $4500 \mathrm{~m}$ deep) since some of the southern species (C. azorica, S. tuberosa) were actually sampled slightly north of the CGFZ (Station 70 and 72) but it is more likely in combination with environmental changes in the CGFZ area. It is also interesting to notice that two (G. hentscheli, S. rhaphidiophora) out of the five species are strict Arctic species, which manage to extend their southern distribution range to the CGFZ, probably by following the southward flow of cold deep waters (Iceland-Scotland Overflow Water: ISOW) along the Reykjanes Ridge.

The CGFZ area has already been considered a major biogeographic transition zone for many planktonic, pelagic or benthic organisms, (Mironov \& Gebruk, 2006; Gebruk et al., 2010; Vecchione et al., 2010; Alt et al., 2013). However, one should keep in mind that the CGFZ may not be a boundary for all marine organisms: Kongsrud et al. (2013) do not find a difference in the species composition of benthic polychaetes north and south of the CGFZ and wish for more samples to settle the matter. Watling et al. (2013) delineated global lower bathyal biogeographic provinces $(801-3500 \mathrm{~m})$ but were unsure of the boundaries for many of them. In our opinion, the CGFZ could be considered as the MAR biogeographic boundary between the two lower bathyal provinces $\mathrm{BY}_{2}$ (North Atlantic Boreal) and $\mathrm{BY}_{4}$ (North Atlantic) (Watling et al., 2013).

\section{The distribution of deep-sea sponges in the North Atlantic}

Numerous studies from shallow water demosponges suggest that sponge larvae are generally short-lived, thus suggesting that short-distance dispersal may be the rule in shallow waters (Uriz \& Turon, 2012). There are currently no behavioural or ecological studies on deep-sea demosponge larvae. 
One study on the Hexactinellida Oopsacas minuta (considered to be a Mediterranean deep-sea species) showed that most larvae settle and metamorphose into the juvenile sponge within 12-24 h after release from the parent (Leys et al. 2007). So deep-sea sponge larvae may have similar behaviour and short-life expectancies as shallow species and thus have short-dispersal potential. Keeping this in mind, knowing that the CGFZ represents a border between two deep-sea sponge faunas partially hints at the environmental parameters that might influence and limit the distribution of deep-sea sponges. Temperature, salinity and oxygen are very similar at the north and the south of the CGFZ (Table 1) but other environmental parameters related to depth may influence the distributions of deep-sea sponges.

Even though we acknowledge that the distribution maps presented in this study closely mirror overall sampling efforts, one should remember that the North Atlantic is probably the best studied and explored deep-sea area in the world. So we can consider most of these distribution maps (for all the Astrophorina: Thenea spp., Geodia spp., S. tuberosa, P. compressa, S. fortis) as good approximations of the current distribution of these species. Although these maps suggest wide distributions for these deep-sea sponges, depth clearly seems to be a limiting factor. Geodia barretti is the most widely distributed species of our collection, probably because it is the most common large Geodia of the North Atlantic, with one of the widest bathymetric ranges (30-2000 m) (Cárdenas et al., 2013). Geodia phlegraei was commonly observed and collected at $3000 \mathrm{~m}$ on Orphan Knoll (north of Flemish Cap) (Cárdenas et al., 2013) and we examined a specimen of Geodia megastrella collected at $4152 \mathrm{~m}$ depth on the Atlantic continental margin off France (MNHN-DCL2857): both of these species were present in the MAR-Eco material. Thenea valdiviae also has a large track record since it is easily collected in soft sediments, with an even wider bathymetric range $(100-3046 \mathrm{~m})$. So most deep-sea demosponge species have bathymetric records that rarely go beyond $3000 \mathrm{~m}$ depth, which thus probably reflects a true lower limit. Of course, there are a few typical deep-sea North Atlantic demosponges that live in the deeper abyssal plains (Barthel \& Tendal, 1993), but these species were not found in the MAR so our discussion will focus on bathyal demosponges. The $3000 \mathrm{~m}$ depth limit of bathyal demosponges was confirmed by direct observations when exploring the $4500 \mathrm{~m}$ deep CGFZ with manned-submersibles, Geodia (called 'round sponges' in Felley et al. (2008)) were not found deeper than $3000 \mathrm{~m}$ and most were found shallower than $2500 \mathrm{~m}$ depth (Felley et al., 2008; Gebruk \& Krylova, 2013). Hexactinellida are also fairly common and diverse around $2500 \mathrm{~m}$ depth but they can also occur deeper than $3000 \mathrm{~m}$ (Felley et al., 2008; Gebruk \& Krylova, 2013). Interestingly, most corals in the CGFZ (Felley et al., 2008) also share this lower limit of $3000 \mathrm{~m}$. So depth is certainly a limiting factor for the dispersal and distribution for most Demospongiae and Hexactinellida. If these species are restricted to the lower bathyal depth layer $(800-3500 \mathrm{~m})$ it means they can disperse without much depth restrictions in the boreo-arctic region, especially in the ShetlandFaroe-Iceland-south Greenland arc where depth does not exceed $3500 \mathrm{~m}$ (Figure 1). This would explain why we have so many amphi-Atlantic boreo-arctic sponge species. On the other hand, between $50^{\circ} \mathrm{N}$ and $30^{\circ} \mathrm{N}$ in the North Atlantic, deep basins with plains at abyssal depths $(3500-6500 \mathrm{~m})$
(Figure 1) would greatly limit or even prevent the dispersal of these animals, which usually have short-lived larvae. For instance, at $48^{\circ} \mathrm{N}$, the MAR is about $1000 \mathrm{~km}$ from the closest continental margins (Flemish Cap to the west, Porcupine Bank to the east) (Figure 1). And yet, our results showed that some Lusitanian species were amphi-Atlantic so they manage to disperse across the Atlantic. These deep-sea demosponges would then maybe use the numerous North Atlantic seamounts (Figure 1) and the MAR as 'stepping stones' above the wider ocean basins, although this scenario has never been extensively tested in the North Atlantic and the few genetic studies made tend to give mixed results (Cho \& Shank, 2010; Rowden et al., 2010). It is however a fact that Geodia species are commonly found on the slopes and tops of seamounts (e.g. seamounts south of the Azores or off Portugal), or oceanic islands (Bermudas, Azores).

The CGFZ is characterized by two main deep rift valleys $35 \mathrm{~km}$ apart; they can be up to $4500 \mathrm{~m}$ deep, but are only $10 \mathrm{~km}$ wide (Figure 1) (Priede et al., 2013). CGFZ sponges significantly show clumped distributions, which could only be partially accounted for by their preference for hard substrates (Felley et al., 2008). So it is possible that either larvae are attracted to other conspecific individuals or that larvae settle close to the parents, a common feature in shallow sponge larvae (Uriz \& Turon, 2012). Furthermore, the fact that MAR sponges are mainly restricted to depths $<3000 \mathrm{~m}$ and that dispersal may be over short distances, the $10 \mathrm{~km}$ wide/ $4500 \mathrm{~m}$ deep rifts may represent a true barrier for larvae dispersal. But since Lusitanian species do make it to the northern edge of the CGFZ, larvae must find a way to cross in $1-2$ days the rifts, if we consider them short-lived. Other parameters may be limiting their dispersal further north.

In addition to depth, the distribution of Demospongiae may also be limited by suitable habitats, which may be rocky outcrops (e.g. for Geodia species, $P$. compressa) or soft bottoms (for Thenea or Stylocordyla). Soft bottoms are the most widely distributed habitats in the MAR so they cannot be a limiting factor. As for rocky outcrops, although they only represent $5 \%$ of the MAR, essentially in steep slopes $\left(>30^{\circ}\right)$ flanking the MAR (Niedzielski et al., 2013), they are present throughout the MAR and may therefore not significantly limit the dispersal of sponges which prefer these habitats.

Deep-sea currents may also influence deep-sea sponge dispersal and distribution. In the North Atlantic, the Gulf Stream gives the eastward North Atlantic Current (NAC) which crosses the MAR around the CGFZ (Søiland et al., 2008). The northern edge of the NAC (temperate waters) runs alongside the subpolar front (colder waters) which shifts between $48^{\circ} \mathrm{N}$ and $53^{\circ} \mathrm{N}$ (Søiland et al., 2008). This subpolar front is correlated with a clear faunal discontinuity (Vecchione et al., 2010). Meanwhile, there is an opposite deep current of overflowing high salinity bottom cold water coming from the Arctic: the Iceland-Scotland Overflow Water (ISOW). The ISOW runs southward along the flank of the Reykjanes Ridge and explains why deep-sea Arctic sponges (S. rhaphidiophora and G. hentscheli) reach the CGFZ. In the CGFZ area, the ISOW current flows mainly from east to west (in the opposite direction of the NAC) (Priede et al., 2013) and may therefore limit the dispersal to the north of species sensitive to cold waters. Furthermore, it has been argued that the ISOW does not act as a dispersal route across the ridge since substantial differences in megafaunal invertebrate 
community composition (sponges not included) within the northern part of the CGFZ were observed (Alt et al., 2013), but this needs to be confirmed with a much wider sampling. To conclude, even though the ISOW is the main current along the northern MAR up to the CGFZ, its influence on deep-sea sponge dispersal and distribution is poorly understood. One of the main reasons may be that the ISOW itself is still not fully understood (Kanzow \& Zenk, 2014).

\section{ACKNDWLEDGEMENTS}

We greatly acknowledge in particular Alexander Plotkin and Elena Gerasimova (University of Bergen) for their great efforts in making preparations, measurements and plates, as well as commenting on the manuscript. We wish to acknowledge Jon A. Kongsrud (Museum of Zoology, University of Bergen) for making the material available to us. Egil Severin Erichsen and Irene Heggstad are warmly thanked for helping with the SEM (University of Bergen). Thank you to Ellen Kenchington, Megan Best and Francisco J. Murillo (all at the Bedford Institute of Oceanography, Canada) for sharing samples and records from the NEREIDA project. We take this opportunity to acknowledge the staff involved in the NEREIDA Project carried out on board the Spanish RV 'Miguel Oliver': NEREIDA is a multidisciplinary research project involving scientists from IEO, Fisheries and Ocean Canada (DFO), Natural Resources Canada (NRCAN), Centre for the Environment, Fisheries and Aquaculture Science (Cefas), Instituto de Investigaciones Marinas (CSIC), Secretaría General del Mar (SGM), Polar Research Institute of Marine Fisheries and Oceanography (PINRO) and P. P. Shirshov Insitute of Oceanology (RAS). One comparative specimen of $T$. longipilis came from the cruise EMEPC/G3/Azores 2007 (Task Group for the Extension of the Continental Shelf). Thank you to Anders Larsson (Uppsala University, Sweden) for help using QGIS and Tomasz Niedzielski (University of Wrockaw, Poland) for sharing shapefiles used in Figure 1. We thank Nicole Boury-Esnault (Station Marine d'Endoume, Marseille), Jean Vacelet (Station Marine d'Endoume, Marseille), Michèle Bruni (MOM, Monaco), Erica Mejlon (UPSZMC, Uppsala, Sweden), Kennet Lundin (Göteborg Natural History Museum, Sweden), Mikael Thollesson (Uppsala University, Sweden), Lena Gustavsson and Sven Boström (Swedish Museum of Natural History, Stockholm), Ole S. Tendal (Zoological Museum in Copenhagen, Denmark), Gudmundur Gudmundsson (Icelandic Museum of Natural History, the BIOICE collections), Isabelle Domart-Coulon (Muséum National d'Histoire Naturelle, Paris, France) and Rob van Soest (Naturalis, Leiden, the Netherlands) for sampling, finding records, help in the collections and sharing comparative material.

\section{FINANCIAL SUPPDRT}

P. Cárdenas was supported by the University of Bergen (PhD stipend) and the Swedish Taxonomy Initiative (Svenska artprojektet), project 'dha 154/2011'. H. T. Rapp was supported by the Norwegian Biodiversity Information Centre (Det norske Artsprosjektet 70184219 to HTR), the Norwegian Academy for Science and Letters (the taxonomy fund) and the Norwegian Research Council (through contract number 179560).

\section{SUPPLEMENTARY MATERIAL}

To view supplementary material for this article, please visit http://dx.doi.org/10.1017/So025315415000983

\section{REFERENCES}

Alander H. (1942) Sponges from the Swedish West-Coast and adjacent waters. PhD thesis. Lund University, Göteborg: Henrik Struves.

Alt C.H.S., Rogacheva A., Boorman B., Alan Hughes J., Billett D.S.M., Gooday A.J. and Jones D.O.B. (2013) Trawled megafaunal invertebrate assemblages from bathyal depth of the Mid-Atlantic Ridge $\left(48^{\circ}-54^{\circ} \mathrm{N}\right)$. Deep Sea Research Part II: Topical Studies in Oceanography 98(Part B), 326-340.

Arndt W. (1913) Zoologische Ergebnisse der ersten Lehr-Expedition der P. Scottländerschen Jubiläums-Stifting. Jahresberichte der Schlesischen Gesellschaft für Vaterländische Cultur 90, 110-119.

Arnesen E. (1920) Spongia. Report on the Scientific Results of the "Michael Sars" North Atlantic Deep-Sea Expedition, 1910. Volume 3. Bergen: Bergen Museum, pp. 1-29, pls I-V.

Barthel D. and Tendal O.S. (1993) The sponge association of the abyssal Norwegian-Greenland sea: species composition, substrate relationships and distribution. Sarsia 78, 83-96.

Bergquist P.R. (1980) A revision of the supraspecific classification of the orders Dictyoceratida, Dendroceratida and Verongida (class Demospongiae). New Zealand Journal of Zoology 7, 443-503.

Bergquist P.R. and Hogg J.J. (1969) Free amino acid patterns in Demospongiae: a biochemical approach to sponge classification. Cahiers de Biologie Marine 10, 205-220.

Bergstad O.A. and Gebruk A.V. (2008) Approach and methods for sampling of benthic fauna on the 2004 MAR-ECO expedition to the Mid-Atlantic Ridge. Marine Biology Research 4, 160-163.

Boury-Esnault N., Pansini M. and Uriz M.J. (1994) Spongiaires bathyaux de la mer d'Alboran et du golfe ibéro-marocain. Mémoires $d u$ Muséum National d'Histoire Naturelle 160, 1-174.

Bowerbank J.S. (1858) On the anatomy and physiology of the Spongiadae. Part I. On the Spicula. Philosophical Transactions of the Royal Society of London 148, 279-332, pls XXII-XXVI.

Bowerbank J.S. (1862) On the anatomy and physiology of the Spongiadae. Part III. On the generic characters, the specific characters, and on the method of examination. Philosophical Transactions of the Royal Society of London 152, 1087-1135.

Bowerbank J.S. (1864) A monograph of the British spongiado. Volume 1. London: Ray Society.

Bowerbank J.S. (1866) A monograph of the British spongiado. Volume 2. London: Ray Society.

Brøndsted H.V. (1933) The Godthaab expedition 1928. Porifera. Meddelelser om Grønland 79, 1-25.

Burton M. (1926) Description of South African sponges collected in the South African Marine Survey. Part I. Myxospongia and Astrotetraxonida. Fisheries Bulletin. Fisheries and Marine Biological Survey Division, Union of South Africa Rept. 4 (Special Rept. 9), pp. 1-29, pls I-VI.

Cárdenas P., Menegola C., Rapp H.T. and Díaz M.C. (2009) Morphological description and DNA barcodes of shallow-water 
Tetractinellida (Porifera: Demospongiae) from Bocas del Toro, Panama, with description of a new species. Zootaxa 2276, 1-39.

Cárdenas P., Pérez T. and Boury-Esnault N. (2012) Sponge systematics facing new challenges. Advances in Marine Biology 61, 79-209.

Cárdenas P. and Rapp H.T. (2012) A review of Norwegian streptaster-bearing Astrophorida (Porifera: Demospongiae: Tetractinellida), new records and a new species. Zootaxa 3253, 1-53.

Cárdenas P. and Rapp H.T. (2013) Disrupted spiculogenesis in deepwater Geodiidae (Porifera, Demospongiae) growing in shallow waters. Invertebrate Biology 132, 173-194.

Cárdenas P., Rapp H.T., Klitgaard A.B., Best M., Thollesson M. and Tendal O.S. (2013) Taxonomy, biogeography and DNA barcodes of Geodia species (Porifera, Demospongiae, Tetractinellida) in the Atlantic boreo-arctic region. Zoological Journal of the Linnean Society 169, 251-311.

Cárdenas P., Rapp H.T., Schander C. and Tendal O.S. (2010) Molecular taxonomy and phylogeny of the Geodiidae (Porifera, Demospongiae, Astrophorida) - combining phylogenetic and Linnaean classification. Zoologica Scripta 39, 89-106.

Cárdenas P., Xavier J.R., Reveillaud J., Schander C. and Rapp H.T. (2011) Molecular phylogeny of the Astrophorida (Porifera Demospongiae) reveals an unexpected high level of spicule homoplasy. PLoS ONE 6, e18318.

Carter H.J. (1872) On two new sponges from the Antarctic Sea, and on a new species of Tethya from Shetland; together with observations on the reproduction of sponges commencing from zygosis of the sponge animal. Annals and Magazine of Natural History, Ser. 49 , 409-435, pls XX-XXII.

Carter H.J. (1874) Descriptions and figures of deep-sea sponges and their spicules from the Atlantic Ocean, dredged up on board H.M.S 'Porcupine', chiefly in 1869; with figures and descriptions of some remarkable spicules from the Agulhas Shoal and Colon, Panama. Annals and Magazine of Natural History, Ser. 4 14, 207-221, 245-257, pls. XIII-XV.

Carter H.J. (1876) Descriptions and figures of deep-sea sponges and their spicules, from the Atlantic Ocean, dredged up on board H.M.S 'Porcupine', chiefly in 1869 (concluded). Annals and Magazine of Natural History 4, 226-240; (106): 307-324; (107): 388-410; (108) $458-479$, pls XII-XVI.

Carter H.J. (1883) Contributions to our knowledge of the Spongida. - Pachytragida. Annals and Magazine of Natural History 5, 344-369, pls XIV-XV.

Cho W. and Shank T.M. (2010) Incongruent patterns of genetic connectivity among four ophiuroid species with differing coral host specificity on North Atlantic seamounts. Marine Ecology 31, 121-143.

Chombard C. and Boury-Esnault N. (1999) Good congruence between morphology and molecular phylogeny of Hadromerida, or how to bother sponge taxonomists [abstract]. Memoirs of the Queensland Museum 44, 100.

Copley J.T.P., Tyler P.A., Sheader M., Murton B.J. and German C.R. (1996) Megafauna from sublittoral to abyssal depths along the Mid-Atlantic Ridge south of Iceland. Oceanologica Acta 19, 549-559.

de Laubenfels M.W. (1936) A discussion of the sponge fauna of the Dry Tortugas in Particular and the West Indies in general, with material for a revision of the Families and Orders of the Porifera. Papers from Tortugas Laboratory 30, 1-225, pls 221-222.

Dendy A. (1922) Report on the Sigmatotetraxonida collected by H.M.S 'Sealark' in the Indian Ocean. Reports of the Percy Sladen Trust Expedition to the Indian Ocean in 1905. Volume 7. Transactions of the Linnean Society of London (2), 18(1). London: Cambridge University Press, pp. 1-164, pls. 161-118.
Durán Muñoz P., Sayago-Gil M., Cristobo J., Parra S., Serrano A., Díaz del Rio V., Patrocinio T., Sacau M., Murillo F.J., Palomino D. and Fernández-Salas L.M. (2009) Seabed mapping for selecting cold-water coral protection areas on Hatton Bank, Northeast Atlantic. ICES Journal of Marine Science 66, 2013-2025.

Felley J.D., Vecchione M. and Wilson R.R. Jr (2008) Small-scale distribution of deep-sea demersal nekton and other megafauna in the Charlie-Gibbs Fracture Zone of the Mid-Atlantic Ridge. Deep Sea Research Part II: Topical Studies in Oceanography 55, 153-160.

Fristedt K. (1887) Sponges from the Atlantic and Arctic Oceans and the Behring Sea. Vega-Expeditionens Vetenskap. Iakttagelser (Nordenskiöld) 4, 401-471, pls 422-431.

Gebruk A.V., Budaeva N.E. and King N.J. (2010) Bathyal benthic fauna of the Mid-Atlantic Ridge between the Azores and the Reykjanes Ridge. Journal of the Marine Biological Association of the United Kingdom 90, 1-14.

Gebruk A.V. and Krylova E.M. (2013) Megafauna of the Charlie-Gibbs Fracture Zone (northern Mid-Atlantic Ridge) based on video observations. Journal of the Marine Biological Association of the United Kingdom 93, 1143-1150.

Grant R.E. (1861) Tabular view of the primary divisions of the Animal Kingdom, intended to serve as an outline of an elementary course of recent Zoology, etc. London: Walter and Maberly.

Gray J.E. (1867) Notes on the arrangement of sponges, with the descriptions of some new genera. Proceedings of the Zoological Society of London 2, 492-558, pls XXVII-XXVIII.

Hansen G.A. (1885) Spongiadae. The Norwegian North-Atlantic expedition 1876-1878. Zoologi 13, 1-26, pls I-VII, 21 map

Hentschel E. (1929) Die Kiesel- und Hornschwämme des Nördlichen Eismeers. In Römer F., Schaudinn F., Brauer A. and Arndt W. (eds) Fauna Arctica. Eine Zusammenstellung der arktischen Tierformen mit besonderer Berücksichtigung des Spitzbergen-Gebietes auf Grund der Ergebnisse der Deutschen Expedition in das Nördliche Eismeer im Jahre 1898. Volume 5. Jena: G. Fischer, pp. 857-1042, pls XII-XIV.

Hougaard L., Christophersen C., Nielsen P.H., Klitgaard A. and Tendal O. (1991) The chemical composition of species of Geodia, Isops and Stryphnus (Choristida: Demospongia: Porifera): a comparative study with some taxonomical implications. Biochemical Systematics and Ecology 19, 223-235

Howell K.L., Davies J.S. and Narayanaswamy B.E. (2010) Identifying deep-sea megafaunal epibenthic assemblages for use in habitat mapping and marine protected area network design. Journal of the Marine Biological Association of the United Kingdom 90, 33-68.

Kanzow T. and Zenk W. (2014) Structure and transport of the Iceland Scotland Overflow plume along the Reykjanes Ridge in the Iceland Basin. Deep Sea Research Part I: Oceanographic Research Papers 86, $82-93$.

Kelly M. and Sim-Smith C. (2012) A review of Ancorina, Stryphnus, and Ecionemia (Demospongiae, Astrophorida, Ancorinidae), with descriptions of new species from New Zealand waters. Zootaxa 348o, 1-47.

Kenchington E., Power D. and Koen-Alonso M. (2013) Associations of demersal fish with sponge grounds on the continental slopes of the northwest Atlantic. Marine Ecology Progress Series 477, 217-230.

Klitgaard A.B. (1995) The fauna associated with outer shelf and upper slope sponges (Porifera, Demospongiae) at the Faroe Islands, northeastern Atlantic. Sarsia 80, 1-22.

Klitgaard A.B. and Tendal O.S. (2004) Distribution and species composition of mass occurrences of large-sized sponges in the northeast Atlantic. Progress in Oceanography 61, 57-98. 
Koltun V.M. (1959) [Siliceous horny sponges of the northern and far-eastern seas of the U.S.S.R.] [In Russian]. Opredeliteli po faune SSR, Izdavaemye Zoologicheskim Muzeem Akademii Nauk 67, 1-236.

Koltun V.M. (1966) Four-rayed sponges of Northern and Far Eastern seas of the USSR (order Tetraxonida). Opredeliti Faunei SSSR 90 . (Zoological Institute of the Academy of Sciences of the USSR: Moscow, Leningrad), pp. 1-112, pls I-XXXVIII (in Russian).

Kongsrud J.A., Budaeva N., Barnich R., Oug E. and Bakken T. (2013) Benthic polychaetes from the northern Mid-Atlantic Ridge between the Azores and the Reykjanes Ridge. Marine Biology Research 9, $516-546$.

Kutti T., Bannister R.J. and Fosså J.H. (2013) Community structure and ecological function of deep-water sponge grounds in the Traenadypet MPA -Northern Norwegian continental shelf. Continental Shelf Research 69, 21-30.

Lamarck J.B.P. (1815) Suite des polypiers empâtés. Mémoires du Muséum d'Histoire Naturelle, Paris 1, 69-80, 162-168, 331-340.

Lehnert H. and Stone R.P. (2011) Craniella sputnika sp. nov. (Porifera Spirophorida: Tetillidae) from the Aleutian Islands, Alaska, with suggested nomenclatural changes for the genera Tetilla and Craniella. Journal of the Marine Biological Association of the United Kingdom 91, 321-328.

Lévi C. (1950) Remarques sur la faune des Spongiaires de Roscoff. Archives de Zoologie Expérimentale et Générale 87, 10-21.

Leys S.P., Mackie G.O., Reiswig H.M. and David W.S. (2007) The biology of glass sponges. Advances in Marine Biology 52, 1-145.

Lopes D.A. and Tabachnick K.R. (2013) New data on glass sponges (Porifera, Hexactinellida) of the northern Mid-Atlantic Ridge. Part 1. Farreidae. Marine Biology Research 9, 462-468.

Lovén S. (1868) Om en märklig i Nordsjön lefvande art af Spongia. Öfversigt af Kongl. Vetenskaps-Akademiens Förhandlingar 25, 105-121.

Lundbeck W. (1905) Porifera. (Part II.) Desmacidonidae (pars.). The Danish Ingolf-Expedition 6(2). Copenhagen: BiancoLuno.

Marshall W. (1876) Ideen über die Verwandtschaftscverhältnisse der Hexactinelliden. Zeitschrift für wissenschaftliche Zoologie 27, 113-136.

Menshenina L.L., Tabachnick K.R., Lopes D.A. and Hajdu E. (2007) Revision of Calycosoma Schulze, 1899 and finding of Lophocalyx Schulze, 1887 (six new species) in the Atlantic Ocean (Hexactinellida, Rossellidae). In Custódio M.R., Hajdu E., Lóbo-Hajdu G. and Muricy G. (eds) Porifera research: Biodiversity, Innovation and Sustainability. Proceedings of the 7 th International Sponge Symposium. Rio de Janeiro: Série Livros 28, Museu Nacional, pp. $449-465$.

Meyer B. and Kuever J. (2008) Phylogenetic diversity and spatial distribution of the microbial community associated with the caribbean deep-water sponge Polymastia cf. corticata by $16 \mathrm{~S}$ rRNA, aprA, and amoA gene analysis. Microbial Ecology 56, 306-321.

Minchin E.A. (1900) Chapter III. Sponges. In Lankester E.R. (ed.) A treatise on zoology. Part II. The porifera and coelenterata. London: Adam \& Charles Black, pp. 1-178.

Mironov A.N. and Gebruk A.V. (2006) Biogeography of the Reykjanes Ridge, northern Atlantic. In Mironov A.N., Gebruk A.V. and Southward A.J. (eds) Biogeography of the North Atlantic seamounts. Moscow: KMK Scientific Press, pp. 6-21.

Morrow C. and Cárdenas P. (2015) Proposal for a revised classification of the Demospongiae (Porifera). Frontiers in Zoology 12, 1-27.

Murillo F.J., Muñoz P.D., Cristobo J., Ríos P., González C., Kenchington E. and Serrano A. (2012) Deep-sea sponge grounds of the Flemish Cap, Flemish Pass and the Grand Banks of
Newfoundland (Northwest Atlantic Ocean): distribution and species composition. Marine Biology Research 8, 842-854.

Niedzielski T., Høines Å., Shields M.A., Linley T.D. and Priede I.G. (2013) A multi-scale investigation into seafloor topography of the northern Mid-Atlantic Ridge based on geographic information system analysis. Deep Sea Research Part II: Topical Studies in Oceanography 98(Part B), 231-243.

O'Leary B.C., Brown R.L., Johnson D.E., von Nordheim H., Ardron J., Packeiser T. and Roberts C.M. (2012) The first network of marine protected areas (MPAs) in the high seas: the process, the challenges and where next. Marine Policy 36, 598-605.

Priede I.G., Billett D.S.M., Brierley A.S., Hoelzel A.R., Inall M., Miller P.I., Cousins N.J., Shields M.A. and Fujii T. (2013) The ecosystem of the Mid-Atlantic Ridge at the sub-polar front and Charlie-Gibbs Fracture Zone; ECO-MAR project strategy and description of the sampling programme 2007-2010. Deep Sea Research Part II: Topical Studies in Oceanography 98(Part B), 220-230.

Ridley S.O. and Dendy A. (1886) Preliminary report on the Monaxonida collected by H.M.S. 'Challenger'. Annals and Magazine of Natural History, Ser. 5 18, 325-351, 470-493.

Ridley S.O. and Dendy A. (1887) Report on the Monaxonida collected by H.M.S. 'Challenger' during the years 1873-1876. Report on the Scientific Results of the Voyage of H.M.S. 'Challenger', 1873-1876. Zoology 20, i-lxviii, 1-275, pls I-LI.

Rowden A.A., Dower J.F., Schlacher T.A., Consalvey M. and Clark M.R. (2010) Paradigms in seamount ecology: fact, fiction and future. Marine Ecology 31, 226-241.

Ryan W.B.F., Carbotte S.M., Coplan J.O., O'Hara S., Melkonian A., Arko R., Weissel R.A., Ferrini V., Goodwillie A., Nitsche F., Bonczkowski J. and Zemsky R. (2009) Global Multi-Resolution Topography synthesis. Geochemistry Geophysics Geosystems 10, Q03014.

Sarà M. (1964) Poriferi di acque superficiali $(0-3 \mathrm{~m}$.) del litorale italiano. Annali del Pontificio Istituto Scienze e Lettere S. Chiara XIV, 299-317.

Sars G.O. (1872) On some remarkable forms of animal life from the great deeps off the Norwegian coast. Part 1, partly from posthumous manuscripts of the late Professor Dr. Michael Sars. University Program for the 1rs half-year 1869. Christiania: Brøgger \& Christie.

Schmidt O. (1862) Die Spongien des adriatischen Meeres. Leipzig: Wilhelm Engelmann, pp. i-viii, 1-88, pls. 81-87.

Schmidt O. (1868) Die Spongien der Küste von Algier. Mit Nachträgen zu den Spongien des Adriatischen Meeres (Drittes Supplement). Leipzig: Wilhelm Engelmann.

Schmidt O. (1870) Grundzüge einer Spongien-Fauna des atlantischen Gebietes. Leipzig: Wilhelm Engelmann, pp. iii-iv, 1-88, pls I-VI.

Schmidt O. (1880) Die Spongien des Meerbusen von Mexico (Und des caraibischen Meeres). Heft II. Abtheilung II. Hexactinelliden. Abtheilung III. Tetractinelliden. Monactinelliden und Anhang. Nachträge zu Abtheilung I (Lithistiden). Reports on the dredging under the supervision of Alexander Agassiz, in the Gulf of Mexico, by the USCSS 'Blake'. Volume iii-iv. Jena: Gustav Fischer, pp. 33-90, pls $\mathrm{V}-\mathrm{X}$.

Søiland H., Budgell W.P. and Knutsen Ø. (2008) The physical oceanographic conditions along the Mid-Atlantic Ridge north of the Azores in June-July 2004. Deep Sea Research Part II: Topical Studies in Oceanography 55, 29-44.

Sollas W.J. (1880) The sponge-fauna of Norway; a Report on the Rev. A.M. Norman's Collection of Sponges from the Norwegian Coast. Annals and Magazine of Natural History 5, 396-409, pl. XVII.

Sollas W.J. (1885) A classification of the sponges. Annals and Magazine of Natural History 5, 395. 
Sollas W.J. (1886) Preliminary account of the Tetractinellid sponges dredged by H.M.S. 'Challenger' 1872-76. Part I. The Choristida. Scientific Proceedings of the Royal Dublin Society (new series) 5, 177-199.

Sollas W.J. (1887) Sponges. In Encyclopaedia Britannica. 9th edition. Volume 22. Edinburgh: A. \& C. Black, pp. 412-429.

Sollas W.J. (1888) Report on the Tetractinellida collected by H.M.S Challenger, during the years 1873-1876. Report on the Scientific Results of the Voyage of H.M.S. Challenger, 1873-1876. Zoology 25, 1-458, pls I-XLIV, 451 maps.

Sowerby J. (1806) The British Miscellany: or coloured figures of new, rare, or little known animal subjects; many not before ascertained to be inhabitants of the British Isles; and chiefly in the possession of the author. Volume 1. London: R. Taylor and Co.

Steenstrup E. and Tendal O.S. (1982) The genus Thenea (Porifera, Demospongiae, Choristida) in the Norwegian Sea and adjacent waters; an annotated key. Sarsia 67, 259-268.

Stephens J. (1915) Sponges of the Coasts of Ireland. I.- The Triaxonia and part of the Tetraxonida. Fisheries, Ireland Scientific Investigations 1914, 1-43, pls I-V.

Tabachnick K.R. and Collins A.G. (2008) Glass sponges (Porifera, Hexactinellida) of the northern Mid-Atlantic Ridge. Marine Biology Research 4, 25-47.

Tabachnick K.R. and Menshenina L.L. (2007) Revision of the genus Asconema (Porifera: Hexactinellida: Rossellidae). Journal of the Marine Biological Association of the United Kingdom 87, 1403-1429.

Thomson C.W. (1873) The depths of the sea. London: Macmillan and Co.

Topsent E. (1892) Contribution à l'étude des Spongiaires de l'Atlantique Nord (Golfe de Gascogne, Terre-Neuve, Açores). Résultats des campagnes scientifiques accomplies par le Prince Albert I. Monaco 2 $1-165$, pls I-XI.

Topsent E. (1894) Étude monographique des spongiaires de France I. Tetractinellida. Archives de Zoologie Expérimentale et Générale 3, 259-40o, pls. XI-XVI.

Topsent E. (1901) Considérations sur la faune des spongiaires des côtes d'Algérie. Éponges de la Calle. Archives de Zoologie Expérimentale et Générale 3, 327-370, pls XIII-XIV.

Topsent E. (1904) Spongiaires des Açores. Résultats des campagnes scientifiques accomplies par le Prince Albert I. Monaco 25, 1-280, pls 281-218.

Topsent E. (1911) Sur une magnifique Geodia megastrella Carter du Muséum de La Rochelle. Archives du Musée de la Rochelle (Bulletin de la Société des Sciences Naturelles de la Rochelle) 1-7, pl. 1.

Topsent E. (1913) Spongiaires provenant des campagnes scientifiques de la 'Princesse Alice' dans les Mers du Nord (1898- 1899 - 1906-1907). Résultats des campagnes scientifiques accomplies par le Prince Albert I. Monaco 45, 1-67, pls I-V.

Topsent E. (1923) Spongiaires du Musée Zoologique de Strasbourg. Choristides. Bulletin de l'Institut Océanographique, Monaco 435, 1- 16.

Topsent E. (1928) Spongiaires de l'Atlantique et de la Méditerranée provenant des croisières du Prince Albert ler de Monaco. Résultats des campagnes scientifiques accomplies par le Prince Albert I. Monaco 74, $1-376$, pls I-XI.
Topsent E. (1929) Spongionella Bow. et Cacospongia Schm. Bulletin de l'Institut Océanographique Monaco 537, 1-14.

Uriz M.J. (1981) Estudio sistemático de las esponjas Astrophorida (Demospongia) de los fondos de pesca de Arrastre, entre Tossa y Calella (Cataluña). Boletin (Instituto Español de Oceanografía) 6, $8-58$.

Uriz M.-J., Gili J.-M., Orejas C. and Perez-Porro A.-R. (2011) Do bipolar distributions exist in marine sponges? Stylocordyla chupachups sp. nov. (Porifera: Hadromerida) from the Weddell Sea (Antarctic), previously reported as S. borealis (Lovén, 1868). Polar Biology 34, $243-255$.

Uriz M.J. and Turon X. (2012) Sponge ecology in the molecular era. Advances in Marine Biology 61, 345-410.

Vacelet J. (1969) Éponges de la Roche du Large et de l'étage bathyal de Méditerranée (Récoltes de la soucoupe plongeante Cousteau et dragages). Mémoires du Muséum national d'Histoire naturelle (A, Zoologie) 59, 145-219, pls I-IV.

van Soest R.W.M. (2002) Family Iotrochotidae Dendy, 1922. In Hooper J.N.A. and van Soest R.W.M. (eds) Systema Porifera: a guide to the classification of sponges. Volume 1. New York, NY: Kluwer Academic/ Plenum Publishers, pp. 594-601.

van Soest R.W.M., Cleary D.F.R., de Kluijver M.J., Lavaleye M.S.S. Maier C. and van Duyl F.C. (2007) Sponge diversity and community composition in Irish bathyal coral reefs. Contributions to Zoology 76, $121-142$.

Vecchione M., Bergstad O.A., Byrkjedal I., Gebruk T.F.V., Godø O.R., Gislason A., Heino M., Høines Å.S., Menezes G.M.M., Piatkowski U., Priede I.G., Skov H., Søiland H., Sutton T. and Wenneck T.d.L. (2010) Biodiversity patterns and processes on the Mid Atlantic Ridge. In McIntyre A.D. (ed.) Life in the world's oceans: diversity, distribution, and abundance. Chichester: Wiley-Blackwell, pp. $103-121$.

von Lendenfeld R. (1888) Descriptive catalogue of the sponges in the Australian museum, Sidney. London: Taylor \& Francis.

von Lendenfeld R. (1907) Die Tetraxonia. Wissenschaftliche Ergebnisse der Deutschen Tiefsee-Expedition auf dem Dampfer Valdivia 18981899 11, i-iv, 59-374, pls IX-XLVI.

Vosmaer G.C.J. (1883) Studies on Sponges. I. On Velinea gracilis, n. g.; n. sp. Mitteilungen aus der Zoologischen Station zu Neapel 4, 437-447, pls $431-432$.

Vosmaer G.C.J. (1885) The Sponges of the 'Willem Barents' Expedition 1880 and 1881. Bijdragen tot de Dierkunde 12, 1-47, pls I-V.

and

Watling L., Guinotte J., Clark M.R. and Smith C.R. (2013) A proposed biogeography of the deep ocean floor. Progress in Oceanography 111, $91-112$.

\section{Correspondence should be addressed to:} P. Cárdenas Department of Medicinal Chemistry, Division of Pharmacognosy, BioMedical Center, Husargatan 3, Uppsala University, 75123 Uppsala, Sweden. email: paco.cardenas@fkog.uu.se 